\title{
New and Little-Known
}

Ammonites from the Upper Cretaceous

(Cenomanian and Turonian)

of the Western Interior

of the United States

GEOLOGIGAL SURVEY PROFESSIONAL PAPER 699

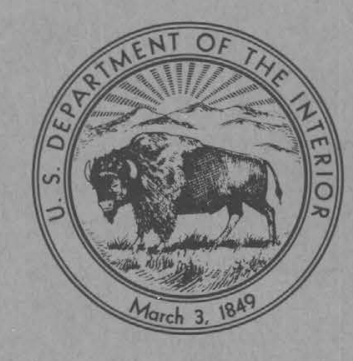



New and Little-Known

Ammonites from the

Upper Cretaceous

(Cenomanian and Turonian)

of the Western Interior

of the United States

By WILLIAM A. COBBAN

GEOLOGICAL SURVEY PROFESSIONAL PAPER 699

$A$ species each of Anisoceras, Desmoceras,

Tragodesmoceras, Calycoceras, Nigericeras,

and Paracompsoceras (new genus) is

described and illustrated

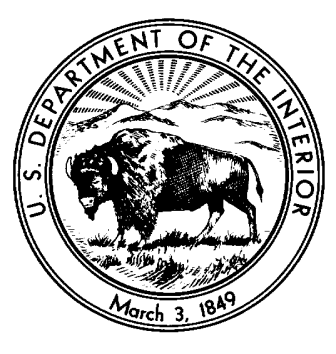

UNITED STATES GOVERNMENT PRINTING OFFICE, WASHINGTON : 1971 


\section{UNITED STATES DEPARTMENT OF THE INTERIOR \\ ROGERS C. B. MORTON, Secretary \\ GEOLOGICAL SURVEY \\ W. A. Radlinski, Acting Director}

Library of Congress catalog-card No. 71-612128 


\section{O N T E T S}

Abstract

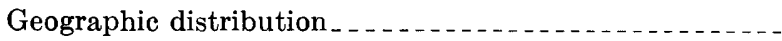

Systematic descriptions

Family Anisoceratidae

Anisoceras plicati

Family Desmoceratidae

Subgenus Moremanoceras, n. subgen Desmoceras (Moremanoceras) scotti Moreman...................

Family Muniericeratidae.

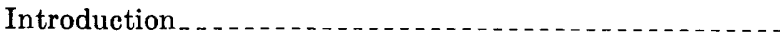

Genus Desmoceras Zittel

\begin{tabular}{|c|c|c|}
\hline Page & & Page \\
\hline 1 & Systematic descriptions-Continued & \\
\hline 1 & Family Muniericeratidae-Continued & \\
\hline 1 & Genus Tragodesmoceras Spath $\ldots \ldots \ldots$ & 8 \\
\hline 4 & Tragodesmoceras carlilense, n. sp_........ & 8 \\
\hline 4 & Family Acanthoceratidae & 10 \\
\hline 4 & Genus Paracompsoceras, n. gen $\ldots \ldots$ & 10 \\
\hline 4 & Paracompsoceras landisi, n. sp.......... & 10 \\
\hline 5 & Genus Calycoceras Hyatt $\ldots \ldots$ & 13 \\
\hline 0 & Calycoceras naviculare (Mantell) .......... & 13 \\
\hline 5 & Family Vascoceratidae & 18 \\
\hline 5 & Genus Nigericeras Schneegans & 18 \\
\hline & Nigericeras scotti, n. sp & 18 \\
\hline 6 & s cited & 20 \\
\hline 8 & 员 & 23 \\
\hline
\end{tabular}

\section{L L U S T R A T I O N S}

[Plates follow index]

Plate 1. Calycoceras naviculare and Anisoceras plicatile.

2. Desmoceras (Moremanoceras) scotti and Paracompsoceras landisi.

3-5. Tragodesmoceras carlilense.

6-8. Paracompsoceras landisi.

9. Nigericeras scotti and Paracompsoceras landisi.

10-17. Calycoceras naviculare.

18. Nigericeras scotti.

FIGURE 1. Index map of part of the western interior region of the United States.

2. Cross sections of Anisoceras plicatile

3. External suture of Desmoceras (Moremanoceras) scotti

4. Diagrammatic outlines of Desmoceras (Moremanoceras) scotti

5. Whorl sections of Desmoceras (Moremanoceras ) scotti

6. Scatter diagrams showing umbilical ratios and number of ventral ribs of Tragodesmoceras carlilense, $\mathrm{n} . \mathrm{sp} \ldots \ldots \ldots$

7. Section through holotype of Tragodesmoceras carlilense, n. sp

8. External suture of Tragodesmoceras carlilense, n. sp

9. Cross sections of holotype of Paracompsoceras landisi, n. sp

10. External suture of holotype of Paracompsoceras landisi, n. $\mathrm{sp}_{\ldots}$

11. Whorl sections of Paracompsoceras landisi, n. sp

12. Scatter diagrams showing umbilical ratios and number of ribs of Calycoceras naviculare

13. Cross sections of Calycoceras naviculare

14. Lateral lobe of Calycoceras naviculare

15. Scatter diagram showing umbilical ratios of Nigericeras scotti, n. $\mathrm{sp}_{\ldots} \ldots$

16. Whorl sections of holotype of Nigericeras scotti, n. sp

17. External sutures of Nigericeras scotti, n. sp

\section{T A B L E S}

TABLE 1. Localities at which fossils were collected.

2. Dimensions, and rib counts of Calycoceras navicular

3. Dimensions and tubercle counts of Nigericeras ocottare 



\title{
NEW AND LITTLE-KNOWN AMMONITES FROM THE UPPER GRETACEOUS (CENOMANIAN AND TURONIAN) OF THE WESTERN INTERIOR OF THE UNITED STATES
}

\author{
By William A. Cobban
}

\begin{abstract}
ABSTRAGT
An example of each of the genera Anisoceras, Desmoceras, Tragodesmoceras, Calycoceras, Nigericeras, and the new genus Paracompsoceras is described from the western interior region. Anisoceras plicatile ( $\mathrm{J}$. Sowerby) and Calycoceras naviculare (Mantell), species described originally from England, are recorded from the Greenhorn Limestone of southeastern Colorado. Desmoceras scotti (Moreman), known previously only from the Eagle Ford Formation of Texas, was discovered recently in the Greenhorn Limestone of southeastern Colorado and in the Mancos Shale of northeastern Arizona. Moremanoceras, a new subgenus, is proposed for this species. The West African lower Turonian genus Nigericeras is recorded for the first time in the western interior; it is represented by $N$. scotti, n. sp. The new genus Paracompsoceras (type species, $P$. landisi, n. sp.) is proposed for a late Cenomanian ammonite from New Mexico that has juvenile whorls resembling those of Acanthoceras and adult whorls resembling those of Acompsoceras. Tragodesmoceras carlilense, n. sp., is described from the lower part of the Carlile Shale of the Black Hills area.
\end{abstract}

\section{INTRODUCTION}

Collections of fossil mollusks made by members of the U.S. Geological Survey include many interesting ammonites that have potential value for the correlation of rocks in the western interior region with those of the Gulf Coastal Plain and even with those of areas as far away as Europe and Africa. Among these ammonites are representatives of the genera Anisoceras, Desmo- ceras, Tragodesmoceras, Calycoceras, and Nigericeras, as well as a new genus, Paracompsoceras. Nigericeras and Paracompsoceras are new discoveries for the western interior. The presence of the other genera in the U.S. Geological Survey's collection has been known for many years although only one species (Tragodesmoceras bassi Morrow) has been described.

All fossils described in this report are stored in the U.S. National Museum in Washington, D.C. Plaster casts of many of the specimens are kept in the U.S. Geological Survey's Mesozoic invertebrate fossil collections at the Federal Center at Denver, Colo. All photographs were made by Robert E. Burkholder, of the U.S. Geological Survey, and some of the whorl sections were drawn by Charles C. Capraro, also of the Geological Survey. Mr. C. W. Wright, London, kindly loaned me English examples of Anisoceras plicatile for comparison with specimens from Colorado.

\section{GEOGRAPHIC DISTRIBUTION}

The ammonites described or recorded in this report were collected at 35 localities in Wyoming, South Dakota, Colorado, Kansas, Arizona, and New Mexico. The general localities are shown in figure 1, and data concerning the localities, stratigraphic position, and collectors are given in table 1. 


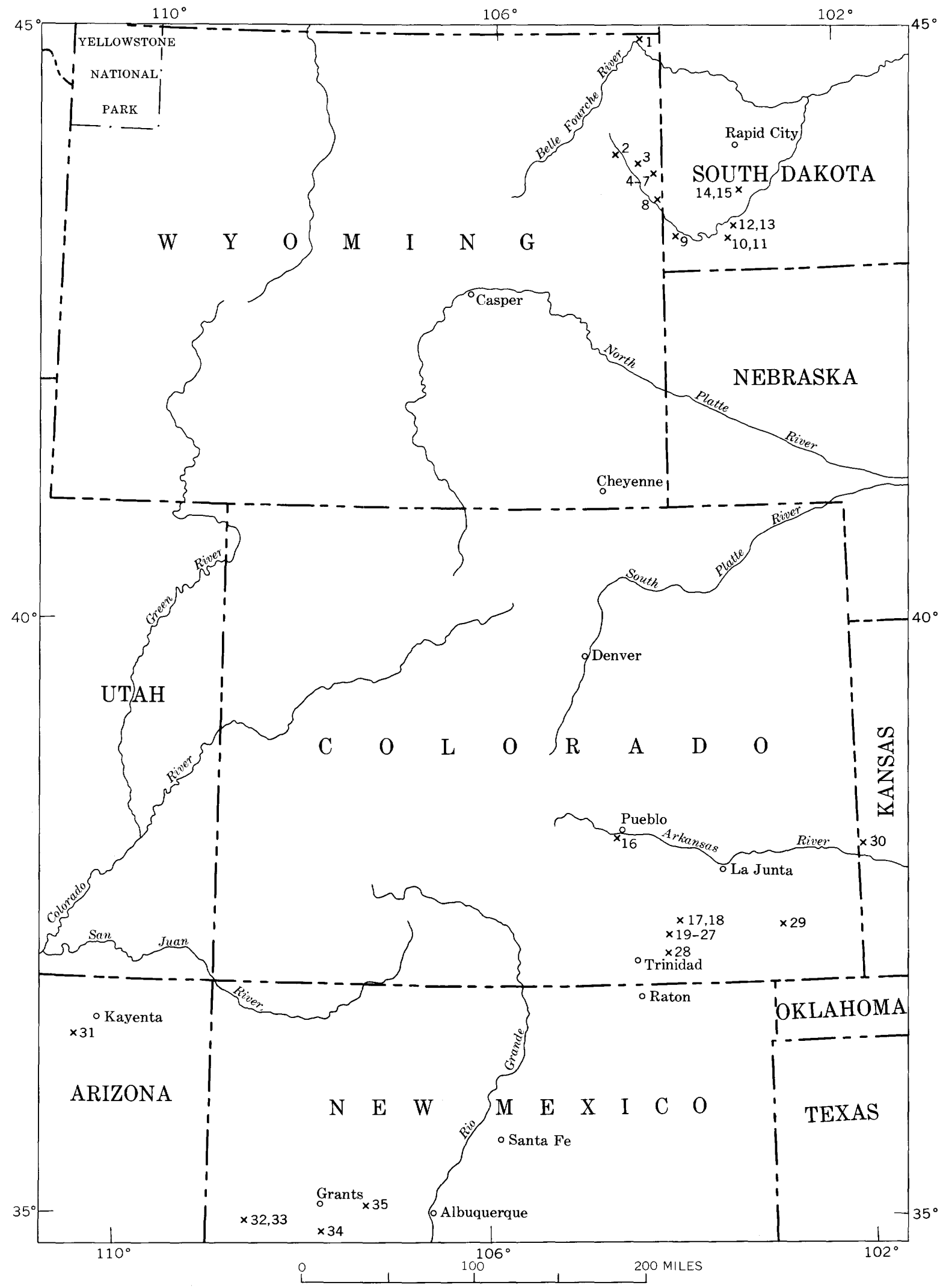

FigurE 1.-Part of the western interior region of the United States showing localities of ammonite collections referred to in the text and in table 1. 
TABLE 1.-Localities at which fossils were collected

Locality
(fig. 1) $\begin{gathered}\text { U.S. Geol. } \\ \begin{array}{c}\text { Mesozoic } \\ \text { locality }\end{array}\end{gathered} \quad$ Collector, year of collection, description of locality, and

$1 \ldots \ldots 21793$ J. B. Reeside, Jr., and W. A. Cobban, 1949. Eight miles southeast of Alzada, in the SW1/4SW1/4 sec. 11 , T. 57 N., R. 62 W., Crook County, Wyo. Carlile Shale, from limestone concretions near base of Pool Creek Shale Member.

2 _... D411 C. MacClintock, 1955. Sec. 19, T. 46 N., R. 63 W., Weston County, Wyo. Carlile Shale, lower part.

3. . _. 11199 W. W. Rubey, 1922. About 11/4 miles east of Pedro Siding, Weston County, Wyo. [Near common corner of secs. $4,5,8$, and $9, \mathrm{~T}$. 45 N., R. 62 W.] Carlile Shale, near base.

4. ... 21792 W. A. Cobban, 1948. One mile southwest of Newcastle in the NW1/4 sec. $31, \mathrm{~T}$. $45 \mathrm{~N}$., R. 61 W., Weston County, Wyo. Carlile Shale, from light-gray-weathering limestone concretions $62 \mathrm{ft}$. above base.

5_._. 11190 C. R. Longwell and W. W. Rubey, 1922. About $2 \frac{1}{2}$ miles south of Newcastle, Wyo. Carlile Shale, near base.

$6 \ldots 12665$ W. W. Rubey, 1924. One mile south of New-

$7 \quad 11192 \quad$ castle, Wyo. Carlile Shale, lower part.

C. R. Longwell and W. W. Rubey, 1922. Two miles northwest of LAK Ranch near Newcastle, Wyo. [sec. 2, T. 44 N., R. 61 W.]. Carlile Shale, lower part.

8_ . _. 26372 D. A. Brobst, 1957. NW $1 / 4$ NW $1 \frac{1}{4}$ sec. 18, T. 42 N., R. 60 W., Weston County, Wyo. Carlile Shale, lower part.

9. ... D3754 W. A. Cobban, 1961. SW $1 / 4 \mathrm{SW}_{1} / 4 \mathrm{SE} 1 / 4$ sec. 6 T. 9 S., R. 2 E., Fall River County, S. Dak. Carlile Shale, from gray limestone concretions about $20 \mathrm{ft}$ below base of Turner Sandy Member.

10_.. D3743 W. A. Cobban, 1961. W1/2NW1/4 sec. 34, T. 8 S., R. 6 E., Fall River County, S. Dak. Carlile Shale, from light-gray limestone concretions about $90 \mathrm{ft}$ above base.

$11 \ldots \ldots$. . . D1417 G. R. Scott and W. A. Cobban, 1957. About $5 \frac{1}{2}$ miles southeast of Hot Springs, in the $\mathrm{NW}^{1 / 4} \mathrm{SE} 1 / 4 \mathrm{NE}^{1 / 4}$ sec. 3, T. 8 S., R. 6 E., Fall River County, S. Dak. Carlile Shale, from the lower shale member.

$12 \ldots$ D1450 J. R. Gill, 1957. NW $1 / 4 \mathrm{NE}^{1 / 1}$ sec. 26, T. 7 S., R. 6 E., Fall River County, S. Dak. Carlile Shale, lower part.

13_._. D1525 D. E. Wolcott and C. E. Price, 1957. North of the center of the SW $1 / 4$ sec. $35, \mathrm{~T} .7 \mathrm{~S}$., R. 6 E., Fall River County, S. Dak. Carlile Shale, lower part.

$14 \ldots 12642$ W. W. Rubey, 1924. Sec. 31, T. 4 S., R. 8 E., Custer County, S. Dak. Carlile Shale, lower part.

$15 \ldots 18872$ N. H. Darton, 1898. Two miles southeast of Fairburn, Custer County, S. Dak. Carlile Shale, lower part.

16 ... 15395 J. H. Johnson, 1930. Rock Canyon anticline just west of Pueblo, Colo. Greenhorn Limestone.

17_._ 1394 G. K. Gilbert, 1894. About 7 miles east of Drip Springs, lat $37^{\circ} 33^{\prime}$ N., long $104^{\circ} 4^{\prime}$ W., Colo. [about $4 \frac{1}{2}$ miles east of Thatcher, Las Animas County]. Greenhorn Limestone.

18_... D6522 G. R. Scott and W. A. Cobban, 1966. Three miles east of Thatcher, in the NW1/4 sec. 6 , T. 29 S., R. 59 W., Las Animas County, Colo. Greenhorn Limestone, near base of Bridge Creek Limestone Member.
TABLE 1.-Localities at which fossils were collected-Continued

\begin{tabular}{|c|c|c|}
\hline $\begin{array}{l}\text { Locality } \\
\text { (fig. 1) }\end{array}$ & $\begin{array}{l}\text { U.S. Geol. } \\
\text { Survey } \\
\text { Mesozoic } \\
\text { locality }\end{array}$ & $\begin{array}{c}\text { Collector, year of collection, description of locality, and } \\
\text { stratigraphic assignment }\end{array}$ \\
\hline
\end{tabular}

$19 \ldots 18676$ N. W. Bass, 1941; G. R. Scott and W. A. Cobban, 1966. W1/2 sec. 15, T. 30, S., R. 60 W., Las Animas County, Colo. Greenhorn Limestone, basal bed of Bridge Creek Limestone Member.

$20 \ldots 18678$ N. W. Bass, 1941; G. R. Scott and W. A. Cobban, 1966. SE $1 / 4$ sec. 12 and NE $1 / 4$ sec. 13 , T. 30 S., R. 60 W., Las Animas County, Colo. Greenhorn Limestone, basal bed of Bridge Creek Limestone Member.

$21 \ldots 18683$ N. W. Bass, 1941; G. R. Scott and W. A. Cobban, 1966. N1/2 sec. 12, T. 30 S., R. 60 W., Las Animas County, Colo. Greenhorn Limestone, basal bed of Bridge Creek Limestone Member.

$22 \ldots \ldots 18684 \quad$ N. W. Bass, 1941. NE1/4 sec. 35, T. 29 S., R. 60 W., Las Animas County, Colo. Greenhorn Limestone, basal bed of Bridge Creek Limestone Member.

$23 \ldots \quad 18685 \quad$ N. W. Bass, 1941. NE $1 / 4$ sec. 35, T. 29 S., R. 60 W., Las Animas County, Colo. Greenhorn Limestone, basal bed of Bridge Creek Limestone Member.

$24 \ldots 18686$ N. W. Bass, 1941; G. R. Scott and W. A. Cobban, 1966. E1/2 sec. 15, T. 30 S., R. 60 W., Las Animas County, Colo. Greenhorn Limestone, basal bed of Bridge Creek Limestone Member.

$25 \ldots$ _. 18687 N. W. Bass, 1941. Sec. 12, T. 30 S., R. 60 W., Las Animas County, Colo. Greenhorn Limestone, basal bed of Bridge Creek Limestone Member.

$26 \ldots 22899$ J. B. Reeside, Jr., H. R. Christner, and W. A. Cobban, 1950; G. R. Scott and W. A. Cobban, 1966. SW1/4 sec. 12 , and $\mathrm{NE}^{1 / 4} \mathrm{NW}^{1 / 4}$ sec. 13 , T. 30 S., R. 60 W., Las Animas County, Colo. Greenhorn Limestone, basal bed of Bridge Creek Limestone Member.

27 _. _ D6530 W. A. Cobban, 1968. SE1/4SE1/4 sec. 3, T. 30 S., R. 60 W., Las Animas County, Colo. Greenhorn Limestone, basal bed of Bridge Creek Limestone Member.

28_ _. D D7030 J. F. Clement, 1959. Sec. 23, T. 31 S., R. 60 W., Las Animas County, Colo. Greenhorn Limestone, basal bed of Bridge Creek Limestone Member.

29__._ D6756 G. R. Scott, 1964; E. R. Landis and W. A Cobban, 1969. Spillway of check dam in the $\mathrm{SE}^{1 / 4}$ sec. 14, T. 29 S., R. 49 W., Baca County, Colo. Greenhorn Limestone, from a 3-in. limestone bed in the lower part.

$30 \quad$ D4870 G. R. Scott and W. A. Cobban 1964. West bank of Bridge Creek in the $\mathrm{E}^{1 / 2} \mathrm{NE}^{1 / 4}$ sec. 22, T. 23 S., R. 42 W., Hamilton County, Kans. Greenhorn Limestone, $4 \mathrm{ft}$ above base of Bridge Creek Limestone Member.

31_. _ D7092 W. A. Cobban, 1969. East side of Longhouse Valley, $13^{2} / 10$ miles south and 13 miles west of the northeast corner of the Kayenta 15minute quadrangle (Navajo planimetric No. 39), Navajo County, Ariz. Mancos Shale, from a limestone concretion at base.

$32 \ldots$ _. $~ D 6159$ E. R. Landis, 1967. East of State highway 32, in the southwest part of T. 9 N., R. 17 W., McKinley County, N. Mex. From a brownweathering sandstone concretion $12 \mathrm{ft}$ above the top of the Dakota Sandstone.

33_. _ D6160 E. R. Landis, 1967. Same locality as D6159. From sandstone $46 \mathrm{ft}$ above top of Dakota Sandstone. 
TABLE 1.-Localities at which fossils were collected-Continued

\begin{tabular}{|c|c|c|}
\hline $\begin{array}{l}\text { Locality } \\
\text { (fig. 1) }\end{array}$ & $\begin{array}{l}\text { U.S. Geol. } \\
\text { Survey } \\
\text { Mesozoic } \\
\text { locality }\end{array}$ & $\begin{array}{c}\text { Collector, year of collection, description of locality, and } \\
\text { stratigraphic assignment }\end{array}$ \\
\hline $34 \ldots$ & D6130 & $\begin{array}{l}\text { E. R. Landis, C. H. Dane, and W. A. Cobban, } \\
1967-69 . \text { North of Little Narrows, about } 15 \\
\text { miles south of Grants, in the SW1/4 sec. } 6 \\
\text { and NW1/4 sec. 7, T. } 8 \text { N., R. } 9 \text { W., Valencia } \\
\text { County, N. Mex. From brown-weathering } \\
\text { sandstone concretions in basal part of } 55-\mathrm{ft} \\
\text { unnamed sandstone and } 187 \mathrm{ft} \text { above base of } \\
\text { Dakota Sandstone. }\end{array}$ \\
\hline $35_{----}$ & D7084 & $\begin{array}{l}\text { E. R. Landis, C. H. Maxwell, and W. A. } \\
\text { Cobban, } 1969 \text {. Three miles north of Laguna, } \\
\text { in the SE1/4SE14NE1/4 sec. 20, T. } 10 \text { N., R. } 5 \\
\text { W., Valencia County, N. Mex. From brown- } \\
\text { weathering sandstone concretions just below } \\
\text { the second sandstone member of the Mancos } \\
\text { Shale (Moench, 1963). }\end{array}$ \\
\hline
\end{tabular}

\section{SYSTEMATIC DESCRIPTIONS}

Phylum MOLLUSCA

Class CEPHALOPODA

Order AMMONOIDEA

\section{Family ANISOCERATIDAE}

Genus ANISOCERAS Pictet, 1854

Type species.-Hamites saussureanus Pictet, 1847.

Anisoceras includes heteromorphic ammonites that have an open helicoid spire in the juvenile stage and a spire that is hooklike in the mature stage. Numerous transverse ribs encircle the limbs; these ribs are weakest on the dorsum. Most of the shells have a row of lateral tubercles and a row of ventral tubercles on each side. The genus is most common in rocks of late Albian and Cenomanian Age.

\section{Anisoceras plicatile (J. Sowerby)}

Plate 1, figures 4-7, text figure 2

1819. Hamites plicatilis J. Sowerby, The Mineral Conchology of Great Britain, v. 3, p. 59 , pl. 234, fig. 1.

1822. Hamites plicatilis J. Sowerby. Mantell, The fossils of the South Downs or illustrations of the geology of Sussex, p. 121, pl. 23, figs. 1, 2.

1872. ?Anisoceras plicatile (J. Sowerby). Schlüter, Palaeontographica, v. 21, p. 114, pl. 34, figs. 6-8.

1939. Anisoceras plicatile (J. Sowerby). Spath, A monograph of the Ammonoidea of the Gault, Palaeontograph. Soc., v. 92 , p. 557 , text figs. $196 \mathrm{e}-\mathrm{h}$.

1959. Anisoceras plicatile (J. Sowerby). Cieślinski, Inst. Geol. [Warsaw] Prace, v. 28, p. 36, pl. 4, fig. 2.

1964. ?Anisoceras plicatile (J. Sowerby). Collignon, Atlas des fossiles caractéristiques de Madagascar (Ammonites) : Republique Malgache, Service Géol., Part II (CGénomanien ), p. 8, 35, pl. 319, figs. 1363-1364; pl. 325, fig. 1453.

Sowerby's original specimen, which apparently has been lost according to Spath (1939, p. 557), consisted of a uniformly curved limb with end diameters of about 14 and $25 \mathrm{~mm}$. Sowerby's illustration shows a moderately fine ribbed limb that has 11-13 rectiradiate ribs crossing the venter in a distance equal to the diameter. Two rows of flat-topped tubercles-a ventrolateral row and a midflank row-are present on each side. Sowerby observed that each tubercle extended over three ribs and that the space separating adjacent tubercles of a row was occupied by two ribs.

Mantell (1822, p. 121, pl. 23, figs. 1, 2) presented drawings of two curved limbs of $A$. plicatile of which the smaller had preserved ventrolateral spines. The other specimen, about $58 \mathrm{~mm}$ long with a maximum whorl height of $18 \mathrm{~mm}$, was later refigured by Spath (1939, text fig. 196f). It has 10 ribs for the diameter and as many as three ribs between adjacent tubercles of a row.

Schlüter (1872, p. 114, pl. 34, figs. 6-8) assigned Sowerby's Hamites plicatilis to Anisoceras and figured a small fragment from the upper Cenomanian of northwestern Germany. His drawings show the tubercles on single ribs that are stronger than the untuberculated ones-a condition possibly exaggerated in the drawings.

Spath (1939, text figs. 196g, h) illustrated an uncrushed specimen of $A$. plicatile from the Cenomanian of Dorset, England. It is about $46 \mathrm{~mm}$ long and has a whorl height of at least $15 \mathrm{~mm}$. Spath presented a perfectly circular cross-sectional drawing which showed rows of equally spaced tubercles. Rib density seems to be about 10 or 11 for the diameter.

Cieśliński (1959, p. 36, pl. 4, fig. 2) described a small fragment of a curved limb from the lower Cenomanian of Poland. The specimen seems to be typical of $A$. plicatile. It has a nearly circular section, ribs number 9 or 10 for the diameter, and tubercles cover two or three ribs.

Collignon (1964, p. 8, 35, pl. 319, figs. 1363-1364; pl. 325, fig. 1453) illustrated three fragments of curved limbs that he assigned to $A$. plicatile. They are from the lower Cenomanian of Madagascar. They have whorl heights from 12 to $19 \mathrm{~mm}$ and circular to stoutly elliptical sections. None closely resembles the specimens of Sowerby, Mantell, or Spath. Two have fewer ribs, and one has more ribs. One specimen that has a rather simple suture has the lateral tubercles nearer the dorsum than does typical $A$. plicatile.

Two specimens that seem assignable to $A$. plicatile came from the basal bed of the Bridge Creek Limestone Member on the Model anticline in southeastern Colorado (fig. 1, loc. 26). Each is a septate internal mold that consists of part of a straight limb and part of an elbow. 
The smaller specimen, $97 \mathrm{~mm}$ long, is crushed laterally. It tapers rapidly from a whorl height of $22.5 \mathrm{~mm}$ to $37 \mathrm{~mm}$, both figures are about equally exaggerated owing to crushing. Ribs are rectiradial, narrowly rounded, narrower than the interspaces, and number 12 or 13 for the shell diameter. They cross the dorsum but they are weaker on the dorsum than on the flanks or venter. The lateral and ventrolateral tubercles are equal in size, are flat topped, and cover two or three ribs. The space separating adjacent lateral tubercles is occupied by two or three ribs. A rib, though not present on the flank between a lateral tubercle and the dorsum, may be present in the area separating that tubercle from the equivalent ventrolateral tubercle; this feature is visible on one of Mantell's specimens (Spath, 1939, text fig. 196f).

The larger specimen, $163 \mathrm{~mm}$ long, has end-whorl heights of 35.5 and $56 \mathrm{~mm}$. It shows evidence of some lateral crushing, which may account for the elliptical cross section (fig. 2). Ribs are very narrowly rounded, rectiradiate on the elbow, and rursiradiate on the shaft. They number 10 for the diameter. Tubercles are flat topped and lie on one or two ribs. The space between adjacent lateral tubercles contains two or three ribs. An extra rib may be present here and there on that part of the shell ventral from the lateral tubercles.

Although both specimens seem to be entirely septate, the suture is barely visible and cannot be accurately reproduced. It appears to be highly complex with very narrow and lengthy branches.

Types.-Hypotypes USNM 166337, 166338.

Occurrence.-Both specimens are from the basal bed of the Bridge Creek Limestone Member of the Greenhorn Limestone at USGS Mesozoic locality 22899 near
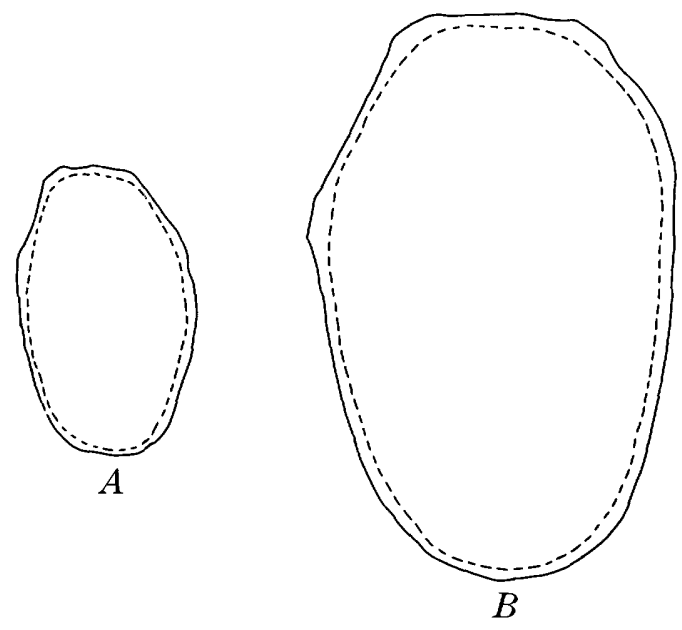

Figure 2.-Cross sections, natural size, of Anisoceras plicatile (J. Sowerby) from USGS Mesozoic locality 22899 (fig. 1, loc. 26). A, Hypotype USNM 166337 at diameter of $29 \mathrm{~mm}$. $B$, Hypotype USNM 166338 at diameter of $56 \mathrm{~mm}$.
Model, Colo. (fig. 1, loc. 26). They were associated with Inoceramus pictus J. de C. Sowerby, Sciponoceras gracile (Shumard), Desmoceras (Moremanoceras) scotti (Moreman), Calycoceras naviculare (Mantell), Pseudocalycoceras dentonense (Moreman), Kanabiceras septemseriatum (Cragin), and Metoicoceras whitei Hyatt. A very late Cenomanian age is indicated by the presence of the species Calycoceras naviculare and by the genus Pseudocalycoceras.

\section{Family DESMOCERATIDAE}

\section{Genus DESMOCERAS Zittel, 1884}

Type species-Ammonites latidorsatus Michelin, 1838. Desmoceras has been described by many authors. Wright (1957, p. L370) summarized the generic characters as

Moderately to very involute, inflated with depressed rounded subquadrate or oval whorl section; sigmoid constrictions form strong rounded ribs on outside of test, with dense striae or weak rounded ribs between them on outer part of side and venter. Suture with finely frilled elements and auxilaries in regularly descending series.

Matsumoto (1954, p. 105) noted also that the proportion of the umbilicus to the diameter (umbilical ratio) was 20 percent or less, and measurements presented by him (Matsumoto, 1953, p. 249, 250) for D. latidorsatum (Michelin), as well as for many examples of $D$. kossmati Matsumoto, show that the ratio ranges from 11 to 18 percent.

Subgenus MOREMANOCERAS Cobban, n. subgen.

Type species-Tragodesmoceras scotti Moreman, 1942.

This new subgenus differs from Desmoceras chiefly by having a simpler suture with broader lateral lobe and shorter auxiliary lobes (fig. 3). Constrictions, which are present by the juvenile stages, disappear and then are rejuvenated in the late adult stage. The subgenus is known only by the type species, which I believe is very late Cenomanian in age. It has been found in Texas, Colorado, and Arizona.

The generic assignment of the type specimen has been controversial. Moreman (1927, p. $94 ; 1942$, p. 208) assigned it first to Pachydiscus and then to Tragodesmoceras. Matsumoto (1960, p. 46) considered it a possible Onitshoceras Reyment (1954, p. 248). Reyment's genus resembles Moremanoceras in its form and sculpture, but its suture is very different. The two suture drawings presented by Reyment (1954, text figs. $1 \mathrm{~b}, \mathrm{c})$ obviously differ from the sutures of Moremanoceras and Desmoceras s.s. by having broad saddles and 

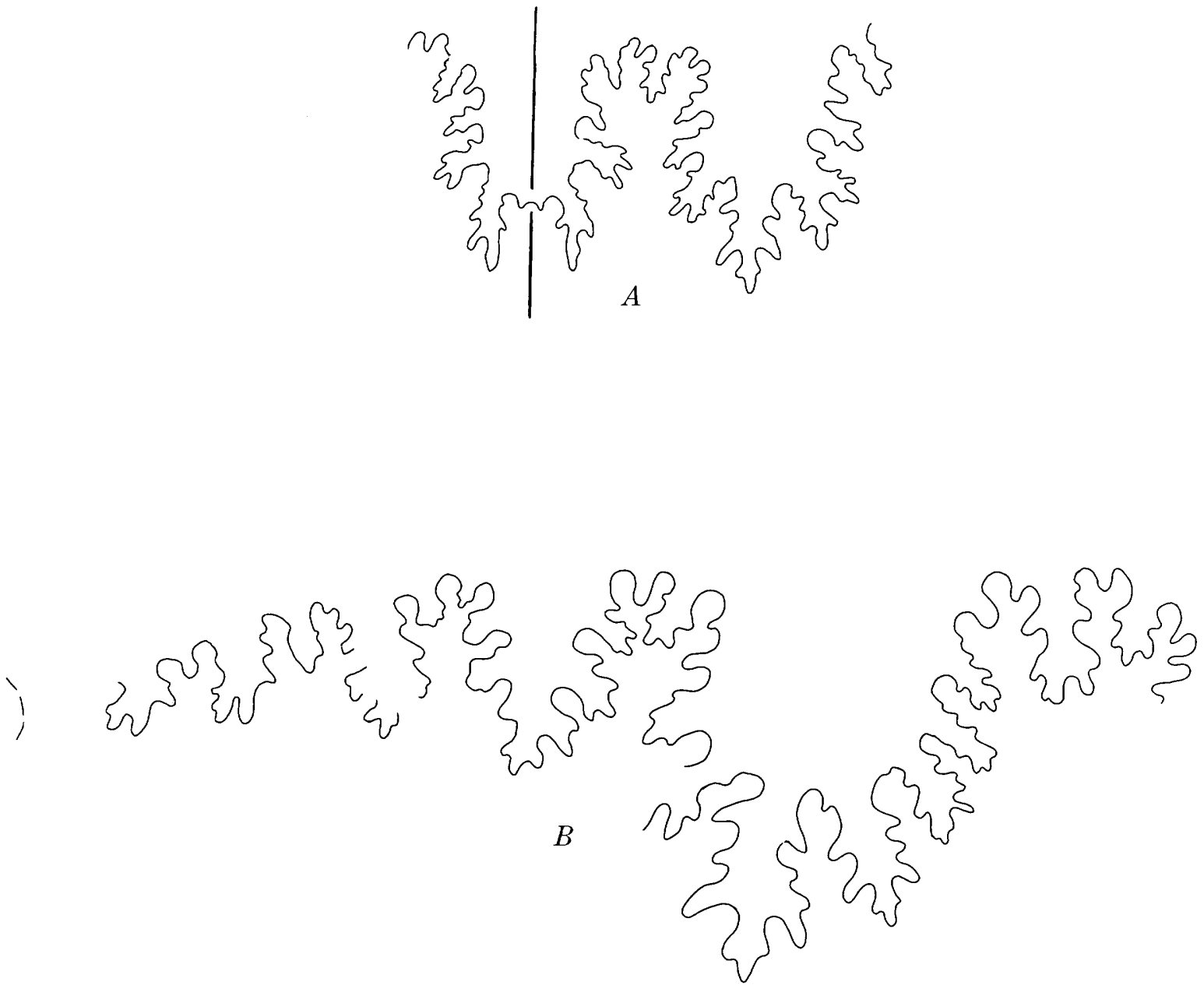

Figure 3.-Parts of the external suture of Desmoceras (Moremanoceras) scotti (Moreman) from the Eagle Ford Formation at USGS Mesozoic locality 19716 near Bells, Tex. A, Hypotype USNM 166345, $\times 6$, at diameter of $18.5 \mathrm{~mm}$ (pl. 2, figs. 15-17). $B$, Hypotype USNM 166346, $\times 6$, at diameter of about $28 \mathrm{~mm}$ (pl. 2, figs. 20, 21).

long narrow lobes with slender branches. The lateral lobe of Moremanoceras is larger, broader and more conspicuous than that of Desmoceras latidorsatum (Michelin), the type species of Desmoceras. Michelin (1838, p. 101) did not illustrate the suture of his $A m$ monites latidorsatus, but Salfelid (1919, text fig. 6) showed the complete suture (reproduced by Spath, 1923 , text fig. $9 \mathrm{k}$ ).

\section{Desmoceras (Moremanoceras) scotti (Moreman)}

Plate 2, figures 1-23; text figures 3-5

1927. Pachydiscus sp. A, Moreman, Jour. Paleontology, v. 1, no. 1 , p. 94, pl. 15, fig. 4 .

1942. Tragodesmoceras scotti Moreman, Jour. Paleontology, v. 16 , no. 2 , p. 208 , pl. 33 , fig. 8 ; text fig. 2 d.

1960. Onitshoceras? scott (Moreman). Matsumoto, Kyushu Univ. Fac. Sci. Repts., Geology, v. 5, no. 1, p. 46, text figs. $10 \mathrm{~A}-\mathrm{C}$.
The type specimen, from the Eagle Ford Formation of Texas, may be a nearly complete adult body chamber. Moreman gave its diameter as $66 \mathrm{~mm}$, umbilical width as $7 \mathrm{~mm}$ (11 percent), and maximum whorl width as $26 \mathrm{~mm}$. The whorl section is higher than wide and has a well-rounded venter, broadly rounded flanks, and sharply rounded umbilical shoulder. Conspicuous rounded ribs, numbering six per half whorl, begin at the umbilical shoulder, trend straight across the flank, and arch forward on crossing the venter. Numerous striae parallel the ribs. Only bits of the last suture are preserved.

Inasmuch as Moreman described only the one specimen, presentation of additional specimens from the Eagle Ford Formation seems advisable. An excellent collection taken from a concretion was made by $H$. $R$. Bergquist of the U.S. Geological Survey about 2 miles northeast of the center of Bells in northeastern Texas 
(USGS Mesozoic loc. 19716). This collection consists of one specimen nearly the size of the holotype and 10 smaller ones $6-35 \mathrm{~mm}$ in diameter. The earliest whorls of the small specimens are very depressed (fig. 4), a character recorded by Matsumoto (1953, p. 248) in his generic diagnosis of Desmoceras. Matsumoto also noted that the later whorls tended to increase in height more rapidly than in width-a feature also apparent in $D$. (M.) scotti (fig. 5). Constrictions first appear at a diameter of 7-8 mm and number three to four per half whorl. At a diameter of $10-11 \mathrm{~mm}$, a rib rises on the apical side of each constriction and parallels the constriction as it arches forward on crossing the venter. As the shell enlarges, the constrictions become weaker and, on some specimens, seem to disappear. The ribs, however, become stronger and persist to the adoral end of the largest specimens. They number three to four per half whorl on the smaller specimens and six on the only large specimen (at a diameter of $54.7 \mathrm{~mm}$ ). Striae parallel the constrictions and ribs. Closely spaced broad weak ribs are present on three individuals at diameters between 25 and $35 \mathrm{~mm}$. One of these individuals, consisting of half a whorl (pl. 2, figs 11-14), shows no evidence of constrictions or the conspicuous bordering ribs.

Desmoceras (Moremanoceras) scotti is represented in the U.S. Geological Survey collections from the western interior region by only two specimens. The larger (pl. 2, figs. 22, 23), $71.5 \mathrm{~mm}$ in diameter, is from the Bridge Creek Limestone Member of the Greenhorn Limestone in southeastern Colorado. It is an internal mold somewhat compressed owing to lateral crushing. The earlier half of the outer whorl lacks constrictions and the associated strong ribs; it is ornamented instead by low closely spaced broad ribs like those on some of
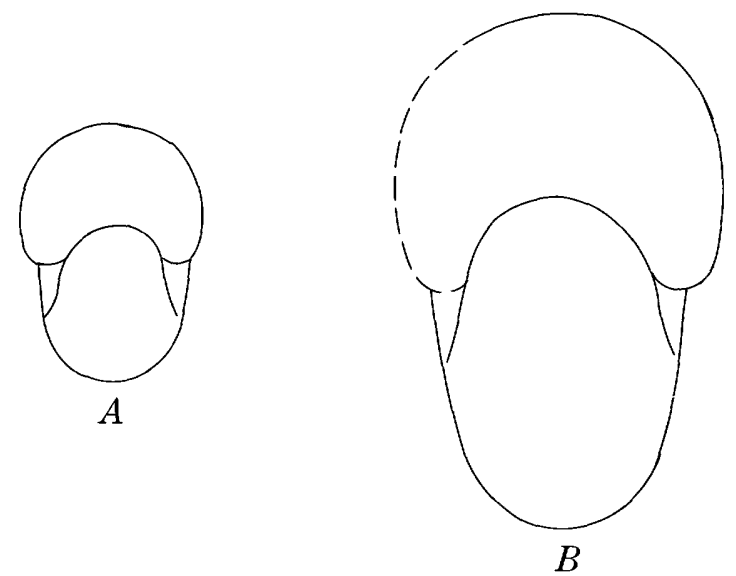

Figure 4.--Diagrammatic outlines, $\times 4$, of front views of Desmoceras (Moremanoceras) scotti (Moreman) from USGS Mesozoic locality 19716. $A$, Hypotype USNM 166339 at diameter of $6.5 \mathrm{~mm}$. $B$, Hypotype USNM 166340 at diameter of $13 \mathrm{~mm}$.
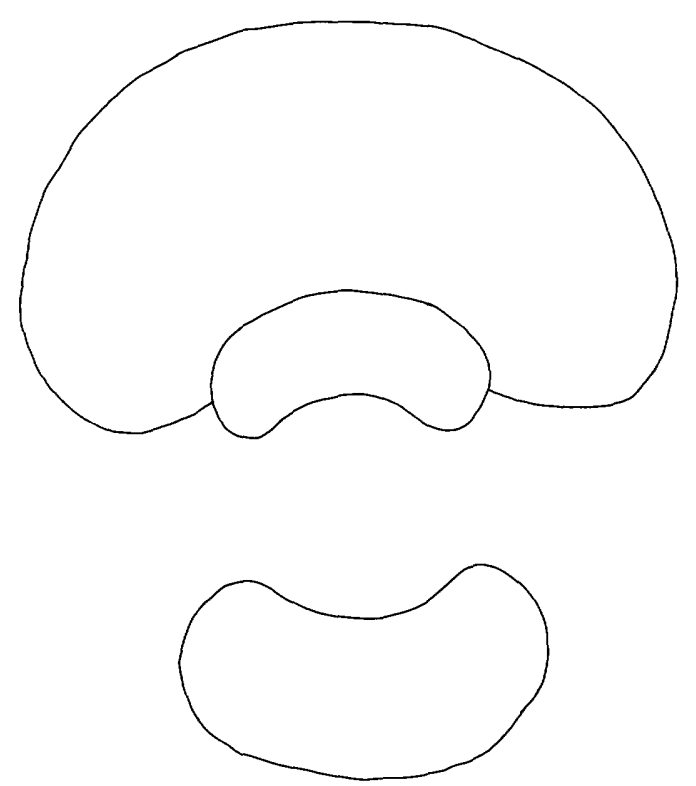

Figure 5.-Whorl sections, $\times 25$, at diameter of $3 \mathrm{~mm}$ of Desmoceras (Moremanoceras) scotti (Moreman) from USGS Mesozoic locality 19716. Hypotype USNM 166339.

the Texas examples. At the beginning of the body chamber (diameter of $48 \mathrm{~mm}$ ), the constrictions are rejuvenated and bounded on their adapical side by strong ribs. Five of these constrictions and associated ribs are present on the last half whorl. Sutures are barely visible.

The other example of $D$. (M.) scotti (pl. 2, figs. 18, 19 ) is an internal mold $49 \mathrm{~mm}$ in diameter from the Mancos Shale in northeastern Arizona. It has weak constrictions and strong border ribs, and the area between these sets is crossed by weak ribs of irregular height. The specimen probably represents the older part of an adult body chamber.

Types.-Hypotypes USNM 166339-166348.

Occurrences.-One specimen was found in the basal bed of the Bridge Creek Limestone Member of the Greenhorn Limestone near Model in southeastern Colorado (fig. 1, loc. 26), where it was associated with Inoceramus pictus (J. de C. Sowerby), Anisoceras plicatile (J. Sowerby), Sciponoceras gracile (Shumard), Calycoceras naviculare (Mantell), Pseudocalycoceras dentonense (Moreman), Kanabiceras septemseriatum (Cragin), and Metoicoceras whitei Hyatt all of very late Cenomanian age. The other specimen came from a limestone concretion at the base of the Mancos Shale on the northwestern side of Black Mesa near Kayenta, Ariz. (fig. 1, loc. 31). Other fossils in the concretion include Inoceramus pictus (J. de C. Sowerby), Pycnodonte newberryi (Stanton), Sciponoceras gracile (Shumard), Worthoceras gibbosum Moreman, and Metoicoceras whitei Hyatt. 


\section{Family MUNIERICERATIdAE}

\section{Genus TRAGODESMOCERAS Spath, 1922}

Type species.-Desmoceras clypealoides Leonhard, 1897.

Spath (1922, p. 127) defined this genus for certain ammonites in the subfamily Puzosinae that have a narrow crenulated venter. He mentioned Desmoceras clypealoides Leonhard (1897, p. 57, pl. 6, figs. 2a, b), Ammonites clypealis Schlüter (1872, p. 51, pl. 15, figs. 9-14), A, hernensis Schlüter (1867, p. 35, pl. 6, fig. 4), and Puzosia muelleri de Grossouvre (1893, p. 172) as representatives of it. Matsumoto $(1954$, p. 111) recommended that Ammonites hernensis Schlüter (1967, not 1872 ) be assigned to Puzosia, and he stated that Puzosia muelleri might be a Nowakites. The other species are characterized by compressed whorl sections, fastigate venters, constrictions, and flexuous ribs that increase in strength toward the venter, which they cross with conspicuous forward arching. The suture resembles that of Desmoceras.

Tragodesmoceras has been recorded only from Germany, France, Sweden, Madagascar, and the United States. The genotype, T. clypealoides (Leonhard), seems to have come from the Turonian of Germany, and all American examples of the genus are Turonian in age.
Schlüter (1876, p. 252) assigned his Ammonites clypealis to the Unter-Senon (Coniacian or Santonian) of Germany. A Santonian age was also assigned to the specimen from Sweden that was identified as Tragodesmoceras cf. T. hernense (Schlüter) by $\emptyset$ dum (1953, p. 24, pl. 4, fig. 3), as well as to the specimen from Madagascar described by Collignon (1966, p. 86, pl. 490, fig. 1974) as the new species $T$. bererense.

Tragodesmoceras carlilense Cobban, n. sp.

Plate 3 , figures 1,2 ; plate 4 , figures $1-16$; plate 5 , figures $1-5$; text figures $6 \sim 8$

This species is represented by 43 very well preserved specimens from limestone concretions in the lower part of the Carlile Shale of the Black Hills region. The specimens range in diameter from $12 \mathrm{~mm}$ to $160 \mathrm{~mm}$.

The umbilicus is sharply defined, and the umbilical ratios of all the specimens but one range from 21 to 26 percent (fig. $6 \mathrm{~A}$ ). The exception is an individual with an umbilical ratio of 19 percent at a diameter of $104 \mathrm{~mm}$. On whorls less than $30 \mathrm{~mm}$ in diameter, the umbilical wall is vertical with sharply rounded shoulders. The umbilical wall begins to slope a little at diameters between 30 to $35 \mathrm{~mm}$, and this slope gradually increases as the shell enlarges. On the largest specimen, the
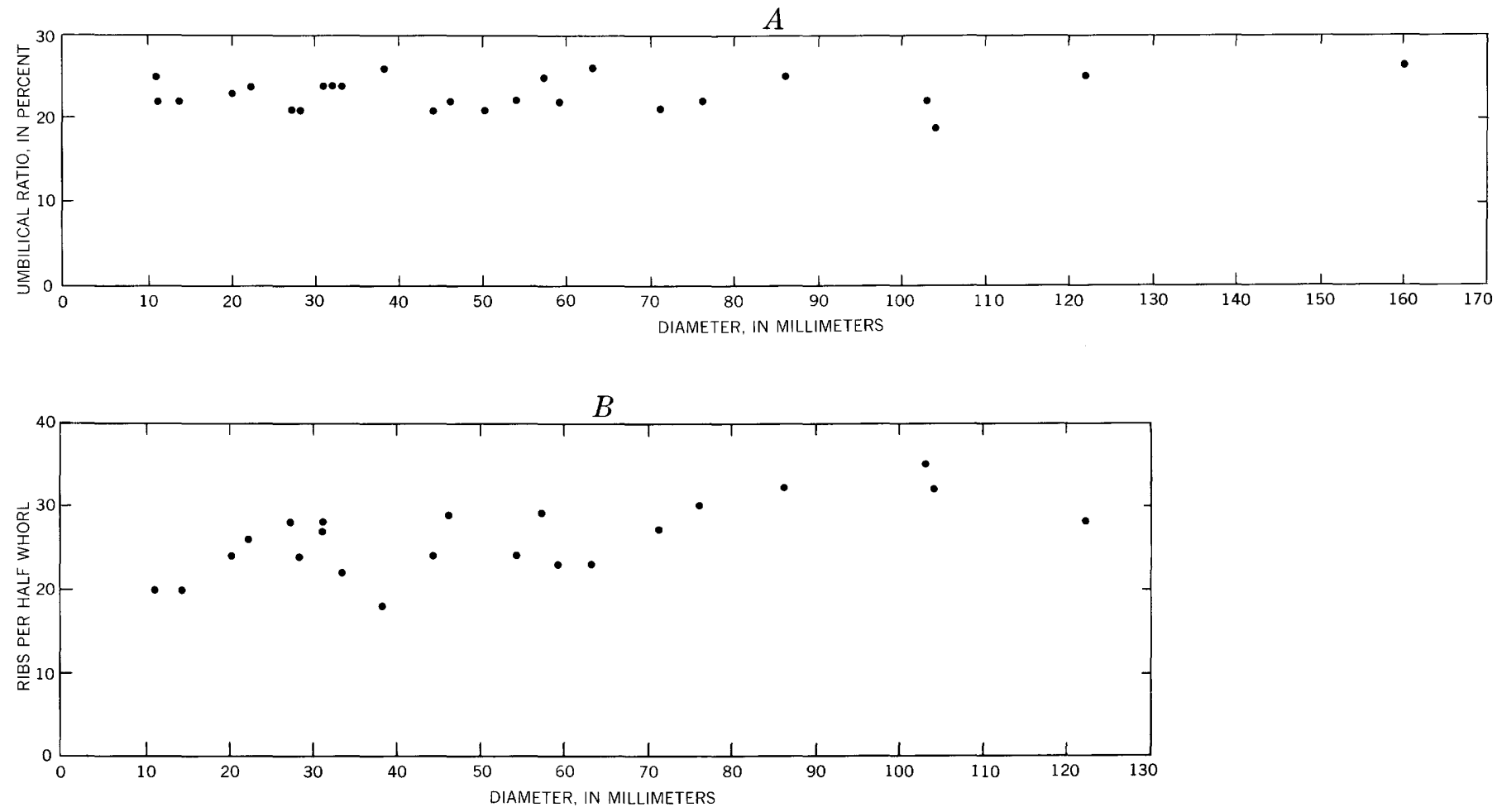

Froure 6. - Scatter diagrams showing umbilical ratios in percent $(A)$ and number of ventral ribs in half a whorl $(B)$ of $T r a g o-$ desmoceras carlitense, n. sp., from the lower part of the Carlile Shale at USGS Mesozoic localities 21792, 11190, 11192, 26372, D3754, D3743, D1417, D1450, 12642, and 18872 (fig. 1, locs. 4, 5, 7-12, 14, and 15). 
umbilical wall forms an angle of $130^{\circ}$ with the flank of the next inner whorl.

The early whorls have stout sections with broadly rounded flanks and arched venters; later septate whorls have flatter flanks and higher and more narrowly arched venters. On the body chamber, the venter broadens and becomes well rounded (fig. 7).

Constrictions, numbering 10-12 per whorl, are conspicuous on the larger internal molds. They are prorsiradiate and slightly flexuous and are bent forward on crossing the venter. They begin at the umbilical shoulder and increase in strength as they cross the flank. Each constriction is bounded on its adapical side by a con-

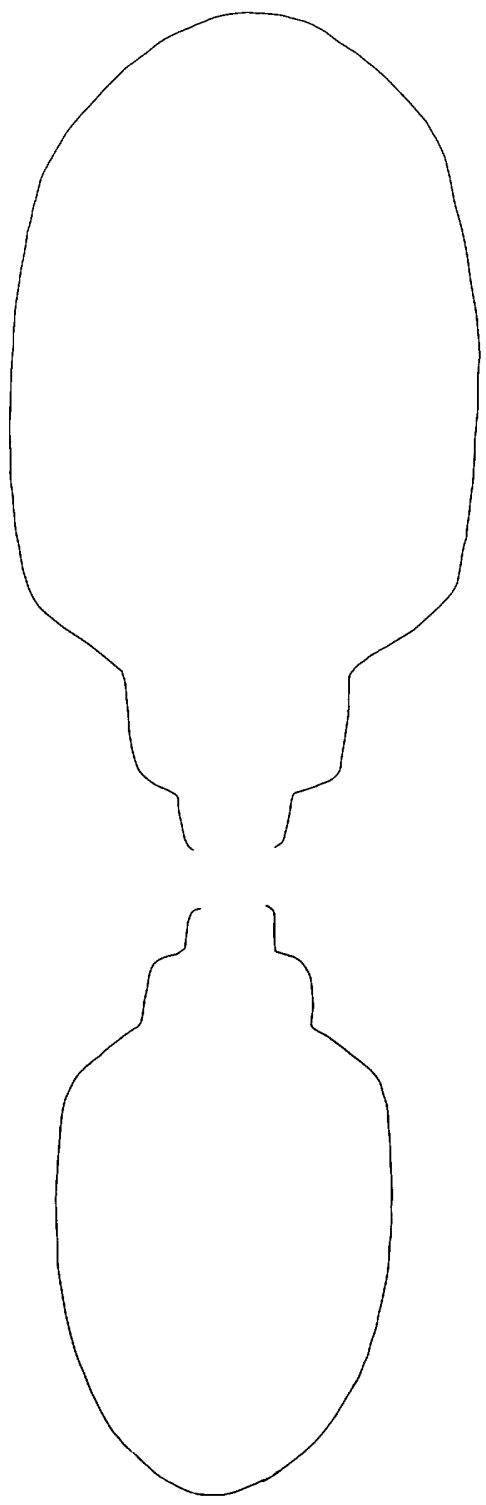

Figure 7.-Section, natural size, through the holotype of Tragodesmoceras carlilense, $\mathrm{n}$. sp., at a diameter of $149 \mathrm{~mm}$. USNM 166349 . spicuous rib. These ribs (primaries) are present on the smallest specimens, but constrictions on most specimens are not well defined at diameters less than 40 or $50 \mathrm{~mm}$.

Two or three orders of ribs are present, and all are strongest on the outer part of the flank and venter (fig. $6 B$ ). Primary ribs are sigmoidal, begin at the umbilical shoulder, and number 14 or 15 per whorl at diameters less than $15 \mathrm{~mm}$ and 16 to 20 per whorl at diameters of 15 to $60 \mathrm{~mm}$. On the outer part of the flank, the primaries of most specimens are separated by two or three secondary ribs of equal lengths. The ribs are strongest at diameters between 10 and $60 \mathrm{~mm}$, and the primaries and the most conspicuous of the secondaries rise into rounded tubercles on the middle of the venter. The ribs greatly weaken on the adult specimens, and the mid-ventral tubercles disappear before the beginning of the body chamber.

The suture (fig. 8) is characterized by a broad, short external (ventral) lobe, a broad trifid lateral lobe, and several bifid or trifid auxiliary lobes progressively decreasing in size toward the umbilicus. It resembles the suture of $T$. clypeale figured by Schlïter $(1872$, pl. 15, fig. 14).

The holotype (pl. 3, figs. 1, 2; pl. 5, fig. 5; text fig. 7) may be an adult. It is $165 \mathrm{~mm}$ in diameter and has a whorl thickness of $54 \mathrm{~mm}$ and an umbilical ratio of 26 percent. A little more than half the last whorl is body chamber.

Tragodesmoceras carlitense is not as densely ribbed as T. clypealoides (Leonhard, 1897, p. 57, pl. 6, figs. 2a, b), which has about 40 ribs per half whorl as compared to 18-35 for the Carlile species. Puzosia muelleri de Grossouvre $(1893$, p. 172 , new name for Ammonites hernensis Schlüter, 1872, p. 40, pl. 11, figs. 12-14, and placed in Tragodesmoceras by Spath, 1922, p. 128), likewise, is much more densely ribbed. Tragodesmoceras hernense (Schülter, 1867, p. 35, pl. 6, fig. 4) from the Turonian of Germany, is possibly the same age as T. carlilense and is as sparsely ribbed, but the umbilicus is wider (32 percent at a diameter of $68 \mathrm{~mm}$ ) and umbilical tubercles are present. Ammonites clypealis Schlüter (1872, p. 51, pl. 15, figs. 9-14), assigned to Tragodesmoceras by Spath (1922, p. 127) but considered to be a Haploceras by Brauns (1875, p. 342), a Muniericeras by de Grossouvre (1893, p. 157), and a Hauericeras by Wegner (1905, p. 207), Stolley (1916, p. 90), and Riedel (1931, p. 693), is also more densely ribbed, and its inner whorls are smooth.

Tragodesmoceras carlilense differs from the slightly older T. bassi Morrow (1935, p. 468, pl. 52, figs. 1a-c; pl. 53, figs. 3-5; text figs. 1, 3), from the Greenhorn Limestone of Kansas and Colorado, by having a slightly narrower umbilicus, stouter whorls, and more ribs per 


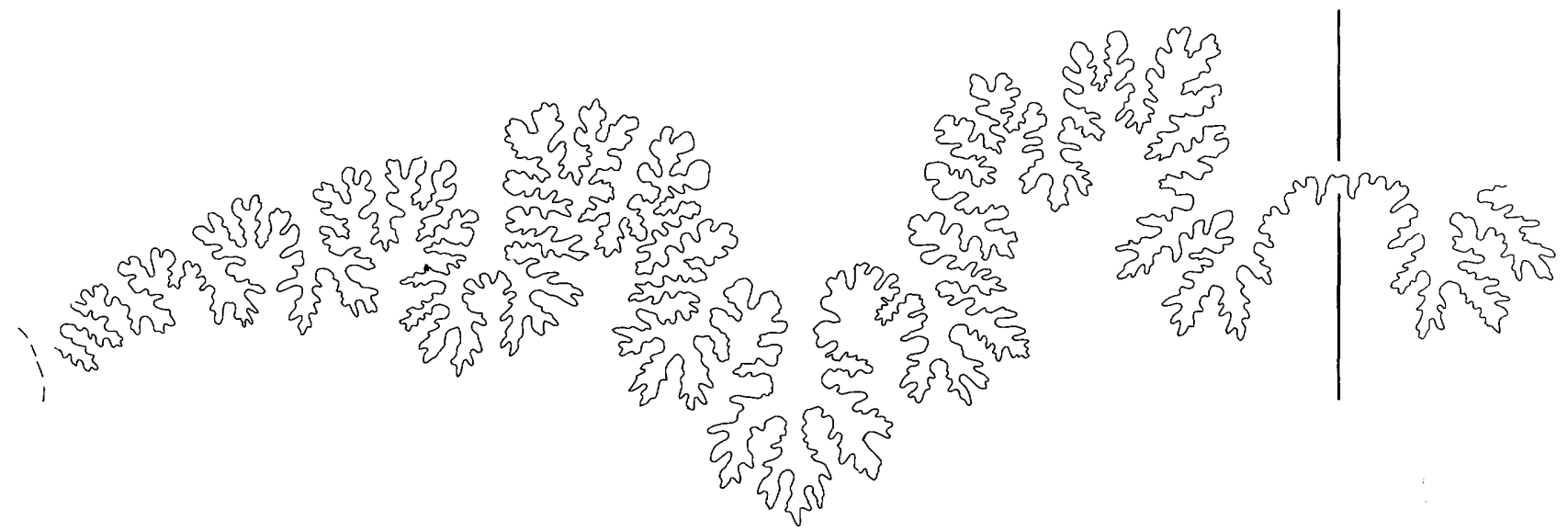

Figure 8. Extermal suture, $\times 2$, of Tragodesmoceras carlilense, n. sp., at diameter of 124 mm (pl. 5, figs. 3, 4). Paratype USNM 166357.

whorl. Specimens from the Turonian of Oregon, described by Anderson (1902, p. 100, pl. 4, figs. 107-109; 1958 , p. 221, pl. 27, figs. 2, 2a) as the new species Desmoceras ashlandicum and Pachydiscus oregonensis and regarded as the one species Tragodesmoceras ashlandicum by Matsumoto (1959, spec. v. 1, p. 26), differ from $T$. carlilense by tending to have a slightly wider umbilicus and coarser and fewer ribs.

Types.-Holotype USNM 166349, paratypes USNM 166350-166357.

Occurrences.-Tragodesmoceras carlitense is known with certainty only from the lowest unit (Pool Creek Shale Member) of the Carlile Shale around the flanks of the Black Hills uplift in northeastern Wyoming and southwestern South Dakota (fig. 1, locs. 1-15). It occurs in gray limestone concretions that also contain Collignoniceras woollgari (Mantell), an ammonite usually assigned an early or middle Turonian age. Tragodesmoceras carlilense is the species listed as Tragodesmoceras, n. sp., in many publications concerning the geology of the flanks of the Black Hills (Cobban, 1951, p. 2188; Brobst, 1961, p. 19; Brobst and Epstein, 1963, table 1; Mapel and Pillmore, 1963b, p. N46; and Robinson, Mapel, and Bergendahl, 1964, p. 67). It has also been listed as Tragodesmoceras sp. and "Puzosia" n. sp. (Mapel and Pillmore, 1963a, p. M36). Sparse impressions of a Tragodesmoceras in the Fairport Chalky Shale Member of the Carlile Shale of Kansas and in the equivalent calcareous shale near Boulder, Colo. suggest that $T$. carlilense may occur there too, but not one of the specimens is well-enough preserved for positive identification.

\section{Family ACANTHOCERATIDAE}

Genus Paracompsoceras Cobban, n. gen.

Type species.-Paracompsoceras landisi Cobban, $\mathrm{n}$.
This genus is proposed for ammonites that have adult whorls similar to those of Acompsoceras Hyatt (1903, p. 111), whereas the juvenile whorls have tubercles like those on juveniles of Acanthoceras Neumayr (1875, p. 929). Paracompsoceras is moderately involute with umbilical ratios ordinarily $25-30$ percent. The umbilical shoulder is rounded but well defined, and the umbilical wall is very steeply sloping or even vertical. Early whorls are quadrangular and ornamented by conspicuour ribs and tubercles. Each rib has a lower and an upper ventrolateral tubercle, and every other rib rises from an umbilical tubercle. On the early whorls a clavate siphonal tubercle is present for each rib. All tubercles and the shorter ribs disappear as the shell enlarges, but the longer ribs tend to persist to the last chambered whorl where they are strongest on the lower (dorsal) half of the flank. Flanks and venter are flattened on the last chambered whorl and on most of the body chamber, and the whorl section is higher than wide. Most or all of the adult body chamber is smooth. The suture is about as incised as that of Acanthoceras, but the branches of the lobes are not quite as long and digitate as those of Acompsoceras. The lateral lobe, which has a broad central stem, is about half as wide as the asymmetrically bifid first lateral saddle. Specimens representing this genus are scarce, and all collected to date are late Cenomanian in age.

\section{Paracompsoceras landisi Cobban, n. sp.}

Plate 2, figures 24-26; plate 6 ; plate 7 ; plate 8 ; plate 9 , figures 5-8; text figures $9-11$

The type lot, from USGS Mesozoic locality D6130 (fig. 1, loc. 34), consists of only six specimens, and all represent complete adult shells or parts of adult shells. Early whorls and sutures were seen best in the holotype (pl. 6; pl. 9, figs. 5-8; text figs. 9, 10) which was taken apart; plaster casts, which are in the U.S. National Museum (Washington, D.C.) and in the U.S. Geological 
Survey's collections of fossils at the Federal Center (Denver), were made of two of the inner whorls before the specimen was restored.

Whorls less than $43 \mathrm{~mm}$ in diameter are not preserved in any of the specimens. At this diameter the intercostal section is very stoutly elliptical and only slightly higher than wide (text fig. 9A). The costal section is squarish and distinctly acanthoceratid with umbilical, lower and upper ventrolateral, and siphonal tubercles. Maximum width is at the umbilical tubercles. A half whorl $70 \mathrm{~mm}$
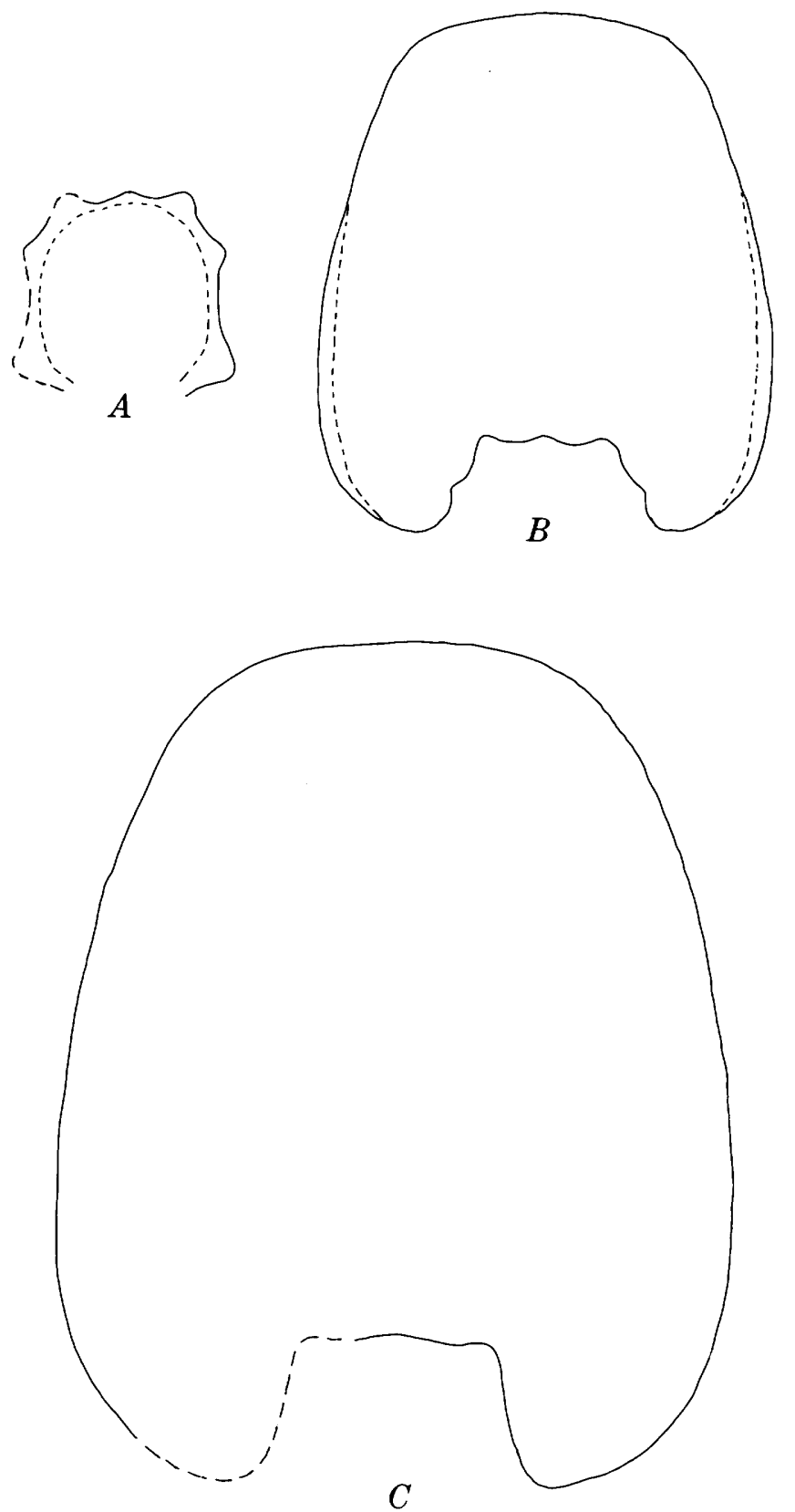

Figure 9.-Cross sections, natural size, of whorls of the holotype of Paracompsoceras landisi, n. sp. USNM 166358. A, Section at a diameter of about $56 \mathrm{~mm}$. B, Section at a diameter of about $120 \mathrm{~mm}$. $C$, Section at a diameter of $202 \mathrm{~mm}$. in diameter has 10 rectiradiate ribs of which every other one (the primary) originates from a strong nodate or bullate umbilical tubercle. The shorter ribs (the secondaries) rise near the middle of the flank and these, as well as the longer ribs, bear nodate lower ventrolateral tubercles and similarly sized clavate upper ventrolateral tubercles. The flattened venter has a low clavate siphonal tubercle for each rib.

As the shell enlarges, all tubercles weaken and disappear, the flanks flatten, and the whorl section becomes rectangular to trapezoidal (text fig. $9 B$ ). On the holotype, the lower ventrolateral tubercles disappear at a diameter of about $70 \mathrm{~mm}$ and the upper ventrolateral ones disappear at a diameter of $105 \mathrm{~mm}$. The longer ribs remain strongest and bullate near the umbilical shoulder, whereas the shorter ones gradually weaken. Twelve primary and secondary ribs are present on half a whorl of the holotype at a diameter of $135 \mathrm{~mm}$ (pl. 9, figs. 7, 8). The secondary ribs disappear near the beginning of the last septate whorl, but in some specimens the primary ribs persist to the end of that whorl or even onto the older part of the body chamber.

The body chamber begins at a diameter of about 220 $\mathrm{mm}$ on the holotype, and at 217 and $257 \mathrm{~mm}$ on the two figured paratypes (pls. 7, 8). The body chamber is largely or entirely smooth. None of the specimens has the peristome preserved. The largest specimen collected has a diameter of $310 \mathrm{~mm}$ (paratype USNM 166395).

The holotype is a moderately stout shell of which the last quarter whorl is part of the body chamber. It has an umbilical ratio of 30 percent at a diameter of $135 \mathrm{~mm}$ and 29 percent at a diameter of $236 \mathrm{~mm}$. An external suture on the last septate whorl is shown in figure 10 .

Although the specimens are few in number, these few suggest a considerable range in stoutness; the holotype lies in the middle of this range. The slenderest specimen (pl. 8), $275 \mathrm{~mm}$ in diameter, has a narrow rectangular section (text fig. 11A) with the greatest width in the middle of the flank. The stoutest individual (pl. 7), $287 \mathrm{~mm}$ in diameter, has a rounded body chamber section (text fig. $11 B$ ).

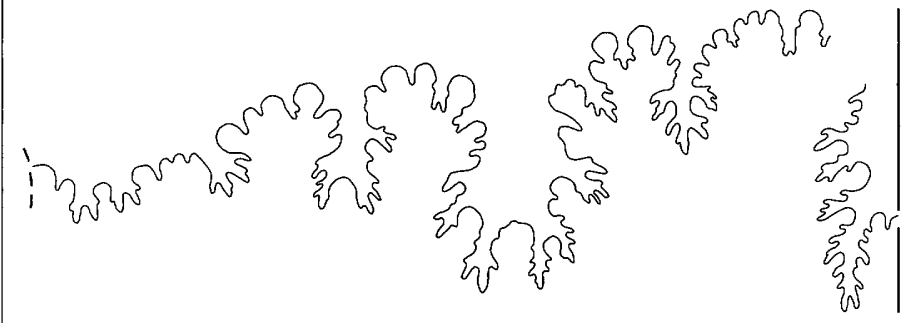

Figure 10.-External suture, natural size, of the holotype of Paracompsoceras landisi, n. sp., at a diameter of $115 \mathrm{~mm}$. USNM 166358. 


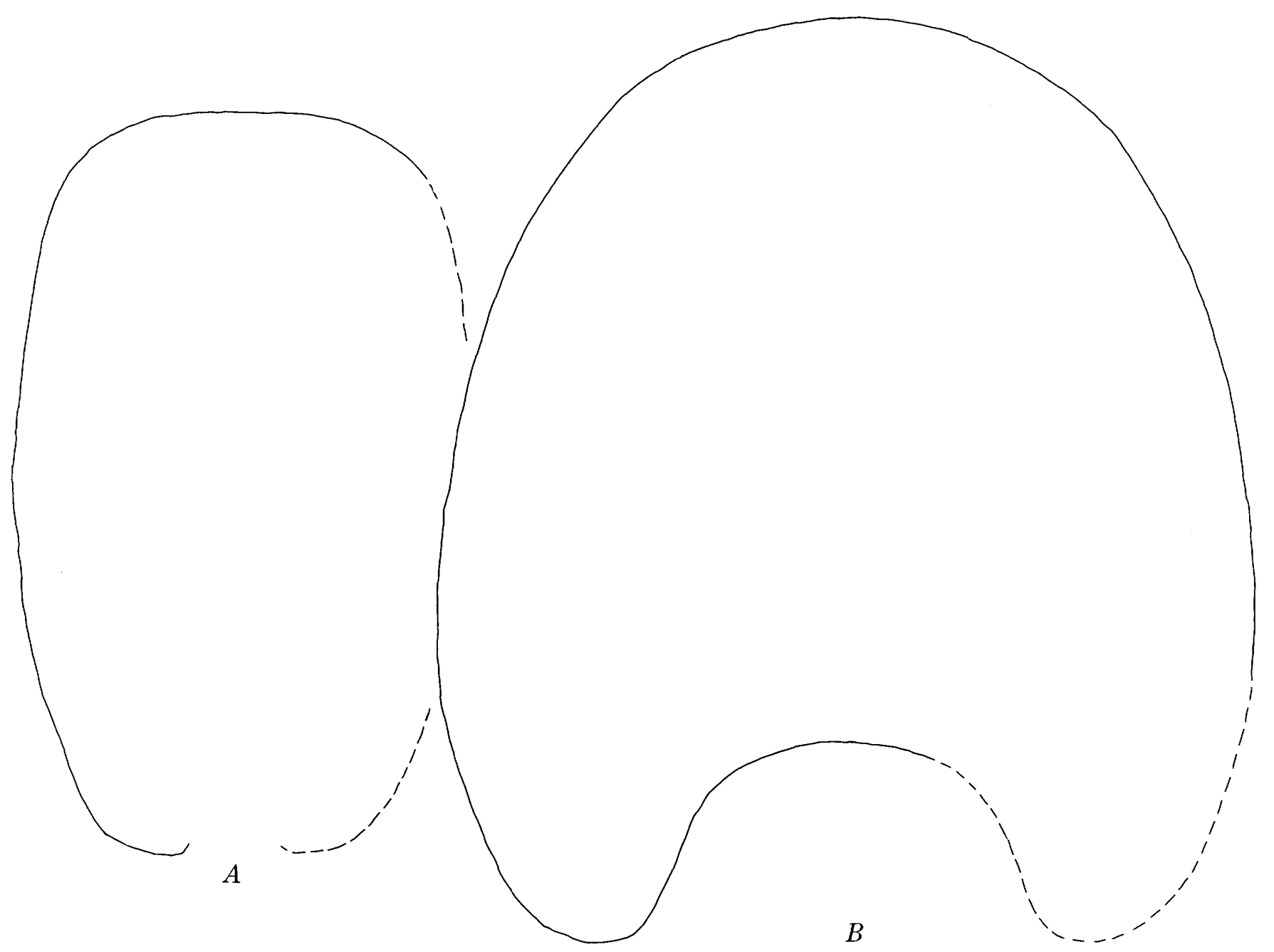

Figure 11. - Whorl sections, natural size, through the body chambers of slender and stout specimens of Paracompsoceras landisi, n. sp. A, Paratype USNM 166361 (pl. 8). B, Paratype USNM 166360 (pl. 7).

The species was named for Edwin R. Landis, of the U.S. Geological Survey, who collected most of the specimens.

Adult specimens of $P$. landisi resemble some adult specimens of Acompsoceras. The bullate ribs and the smooth body chamber of the robust form of $P$. landisi (pl. 7) recall the adult specimen described by Schlüter (1871, p. 1, pl. 1, figs. $1-4$; pl. 2, fig. 1) as Ammonites bochumensis and later designated the type of Acompsoceras by Hyatt (1903, p. 111). The slender form of $P$. landisi (pl. 8), with its smooth outer whorl, resembles that of the adult specimen of Acompsoceras essendiense (Shiuter) var. madagascariensis Collignon (1964, p. 108, pl. 356, fig. 1569). The acanthoceratid juvenile whorls and the smooth or nearly smooth adult body chamber of $P$. landisi are reminiscent of Nigericeras, but that genus lacks the flat-ventered stage and its suture is much simpler.
Types-Holotype USNM 166358, paratypes USNM 166359-166361, 166395.

Occurrences-Paracompsoceras landisi has been found at four localities in northwestern New Mexico (fig. 1, locs. 32-35). The best dated collection is from USGS Mesozoic locality D7084 north 3 miles of Laguna (fig. 1, loc. 35), where the species occurs just below a sandstone mapped as the second sandstone member of the Mancos Shale (Moench, 1963). Other ammonities found just below this sandstone include Acanthoceras amphibolum Morrow and Turrilites acutus Passy subsp. americanus Cobban and Scott, which mark the $A$. amphibolum Zone of the upper Cenomanian of the western interior.

Dr. J. Dan Powell, of the University of Idaho at Moscow, has shown me part of an ammonite from Cerro de Muleros near El Paso, Tex., that may be P. landisi. It was said to have come from subdivision 10 of Böse 
(1910, p. 29) or the Boquillas Formation (Strain, 1968).

\section{Genus CAIYCOCERAS Hyatt in Zittel, 1900}

Type species.-Ammonites navicularis Mantell, 1822.

The characteristics of Calycoceras have been summarized by Matsumoto, Saito, and Fukada (1957, p. $8-9)$ as follows:

Whorls are typically depressed to subrounded, but sometimes not so inflated, having an arched venter. Ribs are elevated but relatively narrow and consist of alternating long and short ones up to the full-grown stage. In the more or less young stage median-ventral, outer and inner ventrolateral and umbilical tubercles are well developed. As a general tendency the outer tubercles are sooner or later weakened or nearly completely obsolete as the shell grows on, while the ribs are prominent throughout life, crossing the external side without weakening. However in some cases the peripheral tubercles persist to, or rejuvenate on, the full-grown, outer whorl. Even in such cases the ribs are still prominent. The suture is similar to that of Mantelliceras.

Calycoceras is widely distributed in rocks of Cenomanian age.

\section{Calycoceras naviculare (Mantell)}

Plate 1 , figures $1-3$; plate 10 , figures $1-8$; plate 11 , figures $1-5$; plate 12 , figures 1,2 ; plate 13 , figures $1-5$; plate 14 , figures $1-3$; plate 15 , figures 1,2 ; plate 16 , figures 1,2 ; plate 17 ; text figures 12-14

1822. Ammonites navicularis Mantell, The fossils of the South Downs or illustrations of the geology of Sussex, p. 198, pl. 22 , fig. 5.

1893. Acanthoceras naviculare (Mantell). Sacco, Soc. Belge Géologie, Paléontologie et Hydrologie Mém., v. 7, p. 18, pl. 2, fig. 1.

1898. Acanthoceras naviculare (Mantell). Choffat, Recueil d'études paléontologiques sur la faune crétacique $d u$ Portugal, v. 1, 2d ser., p. 72 , pl. 4 , figs. $6 a, b ;$ pl. 6 , figs. 1, 2a, b.

1900. Calycoceras (Ammonites) navicularis (ISharp) (sic). Hyatt, in Zittel, Text-book of palaeontology (Eastman translation), p. 589.

1912. Fagesia navicularis (Mantell). De Grossouvre, Soc. Sci. Nat. l'Quest France Bull., ser. 3, v. 2, p. 28, text fig. 3, pl. 3, figs. 1a, b.

1919. Ammonites naviculavis Mantell. Crick, Malacological Soc. London Proc., v. 13, p. 154, pl. 4.

1926. Metacalycoceras naviculare (Mantell). Spath, Geol. Mag., v. 63, no. 740, p. 83.

1926. Metacalycoceras grossouvrei Spath, Geol. Assoc. [London] Proc., v. 37, pt. 4, p. 431.

1931. Acanthoceras borgesi Douvillé, Lisboa Univ. Mus. e Lab. Min. e Geol. Bol., ser. 1, v. 1, no. 1, p. 32, text fig. 2, pl. 2, figs. $3 a, b, 4$.

1931. Metacalycoceras borgesi (Douvillé). Spath, Palaeontograph. Soc. Mon., v. 83, p. 316.

1935. Acanthoceras (Calycoceras) naviculare (Mantell). Karrenberg, Palaeontographica, v. 82 , pt. A, p. 129 , text fig. 1.
1937. Calycoceras (Metacalycoceras) naviculare (Mantell). Collignon, Madagascar Service Mines Annales Géol., pt. 8 , p. 44-49.

1957. Calycoceras naviculare (Mantell). Wright, in Moore, $\mathbf{R}$. C., ed., Treatise on invertebrate paleontology, Part $L$, Mollusca 4, p. LA13, text figs. 531-6, 532.

1957. Calycoceras naviculare (Mantell). Matsumoto, Saito, and Fukada, Kyushu Univ. Fac. Sci. Mem., ser. D, Geology, v. 6, no. 1, p. 9, 10.

1965. Calycoceras grossouvrei Spath. Collignon, Annales Paléontologie, v. 51, p. 172, pl. B, figs. 2a, b.

1968. Calycoceras naviculare (Mantell). Sastry, Rao, and Mamgain, Geol. Soc. India Mem. 2, pl. 1, figs. 5, 6.

1969. Calycoceras naviculare (Mantell). Kennedy, Geologists' Asssoc. Proc., v. 80, pt. 4, pl. 21.

The original description of the type specimen is inadequate (Mantell, 1822, p. 198). The specimen was illustrated by a simple drawing prepared by Mantell's wife and shows an oblique ventral view chiefly of the last half whorl (Mantell, 1822, pl. 22, fig. 5). It was said to have come from the "upper Chalk, Offham" (England).

Almost a century later, Crick (1919, p. 154-155) refigured the holotype and described it as follows:

Mantell's figure of the type-specimen is very misleading. The fossil, which is now in the British Museum collection (register number 5681), is very depressed, having been distorted by pressure; its longest diameter is $149 \mathrm{~mm}$.; many of the ribs are very much worn, but some that are well-preserved show that originally they were narrowly rounded and of the same width as, or even a little narrower than, the intervening spaces; the ribs are straight, and as a rule alternately longer and shorter, but towards the anterior end of the specimen there are irregularities in this respect. As a rule each longer rib commences at the suture [umbilical seam] of the shell and, increasing in strength as it passes across the inner area of the whorl, is raised into a more or less prominent compressed tubercle on the umbilical margin, whence the rib passes straight across the broadlyrounded whorls without any indications of tubercles.

Crick illustrated the specimen by rear and side views which reveal ventrodorsal crushing. Ribs number 17 for half a whorl at a diameter of about $149 \mathrm{~mm}$. Tubercles other than umbilical ones are lacking.

Sharpe $(1856$, p. 39 , pl. 18 , figs. $1-3,5,8)$ illustrated four specimens that he assigned to Ammonites navicularis. All had ventrolateral tubercles, and two had siphonal tubercles also. This assignment of tuberculated specimens to $A$. navicularis led to much confusion for later authors because, in creating the generic name Calycoceras, Hyatt (in Zittel, 1900, p. 589) merely stated " $C$. (Amm.) navicularis, Sharp sp." as the type.

Spath $(1921$, p. 315$)$, in commenting on the resemblance of the inner whorls of the Aptian Cheloniceras gottschei (Kilian) to Calycoceras naviculare, remarked that Mantell's type specimen was "useless" and "too worn and scraped about to show any tubercles $* * *$ 
some of the ribs being artificially carved, or at least scraped, and the original shape of the whorl is quite unrecognisable." Accordingly, Spath selected as a lectotype a specimen that had been illustrated by Sharpe (1856, pl. 18, figs. 1, 8) as an example of Ammonites navicularis. Sharpe's lateral view showed double umbilical tubercles, and Spath mentioned that the specimen had lower and upper ventrolateral tubercles. A few years later, Spath (1926a, p. 83) believed that the specimen he had selected as the lectotype was really a Mantelliceras, and he created the name $M$. cantianum for it. He further stated that "Calycoceras is synonymous with Mantelliceras" and that "since it is also impossible to use the generic name Calycoceras $* * *$ the new name Metacalycoceras gen. nov. is suggested, type to be the example figured by d'Orbigny." The specimen from Sarthe, France, described by d'Orbigny (1840, p. 340, pl. 103, figs. 1-3) as Ammonites mantelli Sowerby and later referred by him (d'Orbigny, 1850, p. 146) to A. navicularis, was subsequently refigured by Collignon (1937, p. 48, pl. 10, figs. 1, 1a, 1b), who named it Metacalycoceras orbignyi. It resemble Mantell's Ammonites navicularis in that it lacks ventrolateral and siphonal tubercles, but it differs in that it has more slender whorls.

The problem of Calycoceras and the species naviculare was reviewed again in 1937 by Spath (p. 278280) and Collignon (p. 44-49). Spath concluded that his Metacalycoceras was a synonym of Calycoceras. Collignon, however, regarded Metacalycoceras as a subgenus of Calycoceras that was characterized by swollen whorls with rounded or transversely ellipical sections, by rather numerous thick ribs tending to curve backward a little, and by only a few tubercles or an early disappearance of tubercles. Mantell's Ammonites navicularies was assigned to this subgenus.

Wright and Wright (1951, p. 25) regarded Metacalycoceras as a synonym of Calycoceras. They pointed out that Hyatt's designation of Calycoceras (Ammonites) naviculare Sharpe sp. was "nomenclatorially irregular" and that according to the International Code of Zoological Nomenclature "a nominal species once selected as type remains the type. Consequently the type species of this genus [Calycoceras] is C. naviculare (Mantell)" and not one of Sharpe's specimens. Wright and Wright $(1951$, p. 26$)$ also noted that $C$. naviculare was "a definite and distinct late form of the genus."

Specimens resembling Mantell's type in their general appearance and by their lack of ventrolateral and siphonal tubercles have been illustrated from Portugal (Choffat, 1898), France (de Grossouvre, 1912; Sacco,
1893), Angola (Douvillé, 1931), Algeria (Collignon, 1965), and India (Sastry, Rao, and Mamgain, 1968). The species has also been recorded from Spain (Karrenberg, 1935, p. 129; Wiedmann, 1959, p. 711, 720, and 1964, p. 109), Tunisia (Pervinquière, 1907, p. 281), and questionably recorded from Madagascar (Collignon, 1964, p. 126, pl. 365, fig. 1596) and Japan (Matsumoto, 1959, p. 64).

Choffat (1898, p. 72, pl. 4, figs. 6a, b; pl. 6, figs. 1, 2a, b) figured as Acanthoceras naviculare a small dorsoventrally crushed specimen and a larger uncrushed specimen from the Cenomanian of Portugal. The smaller specimen, about $47 \mathrm{~mm}$ in diameter, has 18 ribs per half whorl. The larger specimen has 16 ribs per half whorl at a diameter of $125 \mathrm{~mm}$ and an umbilical ratio of 25 percent. Both specimens are very stout and have rectiradiate to slightly rursiradiate ribs that alternate in length. Ventral tubercles are absent on one specimen and probably absent on the other. I regard both as examples of Calycoceras naviculare, although Matsumoto $(1959$, spec. v. 1, p. 78$)$ assigned them to $C$. stoliczkai Collignon.

De Grossouvre (1912, p. 28, pl. 3, figs. 1a, b) figured a stout specimen $82 \mathrm{~mm}$ in diameter that has an umbilical ratio of 28 percent (measurements given by Collignon, 1965 , p. 172). The slightly rursiradiate ribs alternate in length and they number 22 per half whorl. This specimen, designated Fagesia navicularis by de Grossouvre, was said to have come from the lower 'Turonian (Salmurien) of Touvois, France (Loire Inferieure). It seems to be typical of Calycoceras naviculare, although Spath $(1926 \mathrm{~b}$, p. 428,431$)$ regarded it to be a new species-Metacalycoceras grossouvrei.

Douvillé (1931, p. 32, pl. 2, figs. 3a, b, 4; text fig. 2) figured two very well preserved uncrushed specimens from Angola which he considered to be a new speciesAcanthoceras borgesi. One specimen, of which only the ventral view is shown, is $35 \mathrm{~mm}$ in diameter. The other specimen, illustrated by two views, is $100 \mathrm{~mm}$ in diameter and has an umbilical ratio of 30 percent and 16 ribs per half whorl. Douvillé noted the close resemblance in form and ornamentation of his specimens to Mantell's specimen of Ammonites navicularis, but he believed his material should be considered a new species because of differences in the suture pattern. Mantell, however, did not illustrate a suture, and Douvillé regarded the suture drawing presented by d'Orbigny (1840, pl. 103, fig. 3) as representative of the species naviculare. Wright (1957, text figs. 531-6, 532-1) considered Douvillé's Acanthoceras borgesi as a typical Calycoceras naviculare, and he reproduced Douvillé's photographs as an example of the species. I concur with Wright's interpretation and regard Douvillé's species as $C$. naviculare. 
Collignon (1965, p. 172, pl. B, figs. 2a, b) described a specimen from the upper Cenomanian of eastern $\mathrm{Al}$ geria and assigned it to $C$. grossouver (Spath). The diameter is $104 \mathrm{~mm}$ and the umbilical ratio is 25 percent. Ribs alternate in length, and they number 19 on the last half whorl. The specimen was said to be almost identical to the one described from Touvois by de Grossouvre (1912, p. 28, pl. 3, figs. 1a, b) as Fagesia navicularis. Although de Grossouvre said his example came from the lower Turonian (Salmurien), Collignon believed it more likely came from the upper Cenomanian. Collignon's specimen, which apparently lacks tubercles on the ventral part, is interpreted herein as a C. naviculare.

Several ammonites described and illustrated as examples of Calycoceras naviculare have been assigned to other species. The slender English specimen described as Ammonites navicularis by J. de C. Sowerby (1827, p. 105 , pl. 555 , fig. 2) has been assigned to Ammonites [Calycoceras] gentoni Brongniart by Pictet (1863, p. 52) and Crick (1919, p. 156). All four English specimens figured by Sharpe $(1856$, p. 39, pl. 18, figs. 1-3, $5-8)$ as $A$. navicularis have been assigned to other species by Spath $(1921$, p. $315 ; 1926 a$, p. 82-83) and Wright and Wright $(1951$, p. 37). A tuberculated specimen from Bohemia, assigned to Acanthoceras naviculare by Laube and Bruder (1887, p. 239) and closely compared to Sharpe's specimens, does not seem to be true Calycoceras naviculare. Two robust specimens from India figured as $A$. navicularis by Stoliczka (1865, p. 73, pl. 39, figs. 2-4) have been renamed Calycoceras (Metacalycoceras) stolicakai by Collignon (1937, p. $48)$. Boule, Lemoine, and Thevenin $(1907$, p. 30, pl. 8, figs. 1-2) figured two specimens from Madagascar as Acanthoceras naviculare, but neither is that species according to Spath $(1921$, p. 315) and Collignon (1937, p. 48). Another specimen from Madagascar described by Collignon (1931, p. 84, pl. 9, figs. 4, 4a, b) as Acanthoceras (Calycoceras) naviculare has ventrolateral tubercles, a feature which I believe excludes it from assignment to that species.

Ammonites closely resembling Mantell's holotype, as well as comparable specimens figured by Choffat (1898), de Grossourre (1912), Douvillé (1931), and Collignon (1965), are present in the basal bed of the Bridge Creek Limestone Member in the Model dome area of southeastern Colorado (fig. 1, locs. 17-28). They resemble the European and African specimens in their general form, density and arrangement of ribs, presence of umbilical tubercles, and lack of other clearly defined tubercles. Thirty-one specimens are suitable for rib counts and most are suitable also for umbilical ratio
TABLE 2.-Dimensions and rib counts of Calycoceras naviculare (Mantell)

\begin{tabular}{|c|c|c|c|c|}
\hline U.S.N.M. No. & $\begin{array}{c}\text { Diameter } \\
(\mathrm{mm})\end{array}$ & $\begin{array}{c}\text { Umbilical } \\
\text { width (mm) }\end{array}$ & $\begin{array}{c}\text { Umbilical } \\
\text { ratio }\end{array}$ & $\begin{array}{l}\text { Ribs per } \\
\text { half whorl }\end{array}$ \\
\hline \multirow[t]{3}{*}{$166362 \ldots$} & 44. 6 & 12.3 & 0.28 & 20 \\
\hline & 65.3 & 17.3 & 26 & 21 \\
\hline & 95.4 & 27.0 & 28 & \\
\hline \multirow{2}{*}{$166363 \ldots$} & 56.7 & 13.1 & 23 & 19 \\
\hline & 72.6 & 18. 6 & 26 & 20 \\
\hline \multirow{2}{*}{$166372 \ldots$} & 72.1 & 18. 8 & 26 & 18 \\
\hline & $\begin{array}{l}94.3 \\
64.8\end{array}$ & 25.7 & 27 & 18 \\
\hline $166378 \ldots$ & $\begin{array}{r}04.8 \\
106.0\end{array}$ & 32.0 & 30 & $\begin{array}{l}21 \\
20\end{array}$ \\
\hline \multirow[t]{2}{*}{$166376 \ldots$} & 68. 0 & & . & 19 \\
\hline & ca. 157.0 & 204 & & 15 \\
\hline $166381 \ldots \ldots$ & $\begin{array}{r}71.3 \\
160.0\end{array}$ & 20.4 & .28 & $\begin{array}{l}18 \\
17\end{array}$ \\
\hline \multirow{6}{*}{$\begin{array}{l}166371 \\
166368 \\
166370 \\
166386\end{array}$} & 71. 0 & & & 18 \\
\hline & ca. 83.0 & $\ldots$ & - - & ca. 22 \\
\hline & 86. 0 & & & 21 \\
\hline & 93.0 & 26.0 & 28 & 20 \\
\hline & 128.5 & $\ldots$ & $-\ldots$ & 16 \\
\hline & 178. 0 & & & 16 \\
\hline $166369 \ldots$ & 96.0 & & & 17 \\
\hline \multirow{2}{*}{$166382 \ldots$} & 101. 0 & 27.5 & 27 & 21 \\
\hline & 138. 0 & 35.8 & 26 & 20 \\
\hline \multirow{4}{*}{$\begin{array}{l}166390 \ldots \\
166383 \\
166367 \ldots \ldots\end{array}$} & 101.5 & 29.7 & 29 & 18 \\
\hline & 102. 2 & 28.4 & .28 & 19 \\
\hline & 103.8 & 29.2 & .28 & 20 \\
\hline & 148.0 & 43.0 & .29 & 18 \\
\hline \multirow{3}{*}{$\begin{array}{l}166388 \ldots \\
166375 \ldots \ldots\end{array}$} & 107.0 & & & 22 \\
\hline & 110.0 & 32.8 & .30 & 23 \\
\hline & 158.0 & 45.4 & 29 & 22 \\
\hline \multirow{3}{*}{$\begin{array}{l}166384 \ldots \\
166373 \ldots\end{array}$} & 112.0 & 30.0 & 27 & 21 \\
\hline & 112. 0 & 31.5 & 28 & 19 \\
\hline & 133.5 & 39.0 & 29 & 18 \\
\hline \multirow{4}{*}{$\begin{array}{l}166385 \\
166364 \ldots \\
166379\end{array}$} & 113. 0 & 30.3 & 27 & 18 \\
\hline & 118.0 & 33.0 & 28 & 20 \\
\hline & 123.0 & 34.6 & 28 & 15 \\
\hline & 173. 0 & 53.6 & 31 & 13 \\
\hline \multirow{3}{*}{$\begin{array}{l}166387 \\
166394 \ldots\end{array}$} & 126. 0 & 38.9 & 31 & 19 \\
\hline & 127. 0 & 34.6 & 27 & 16 \\
\hline & 198. 0 & 61.3 & .31 & 15 \\
\hline \multirow{2}{*}{$166374 \ldots \ldots$} & 128.0 & 39.0 & 30 & 18 \\
\hline & 167.0 & 50.5 & .30 & 17 \\
\hline \multirow[t]{2}{*}{$166365 \ldots$} & 136. 0 & 43. 3 & .32 & 19 \\
\hline & 173. 0 & 54.8 & .32 & 17 \\
\hline 16639 & 146.0 & 43.5 & .30 & 17 \\
\hline $166377_{\ldots}$ & 159. 0 & 46.0 & .29 & 17 \\
\hline \multirow{2}{*}{166366} & 166. 0 & 44. 3 & .27 & 19 \\
\hline & 220.0 & 68.0 & .31 & 18 \\
\hline \multirow{2}{*}{$\begin{array}{l}166389 \\
166391\end{array}$} & 220.5 & 64.3 & .29 & 15 \\
\hline & 239.0 & 71.7 & .30 & 12 \\
\hline
\end{tabular}

determinations. These measurements are given in table 2 and shown in figure 12.

The umbilical ratios, which range from 23 to 32 percent, gradually increase as the shell enlarges (fig. 12). The umbilical wall is steep and slightly rounded. The umbilical shoulder is well rounded and merges evenly into the broadly rounded flank.

Most whorl sections are wider than high (fig. $13 B$, $D-H$ ), but for a few individuals they may be equal in size or a little higher than wide (fig. 13A, $C^{\prime}$ ). The venter is broadly rounded on juveniles; it tends to become very broadly rounded or even a little flattened on adults. 

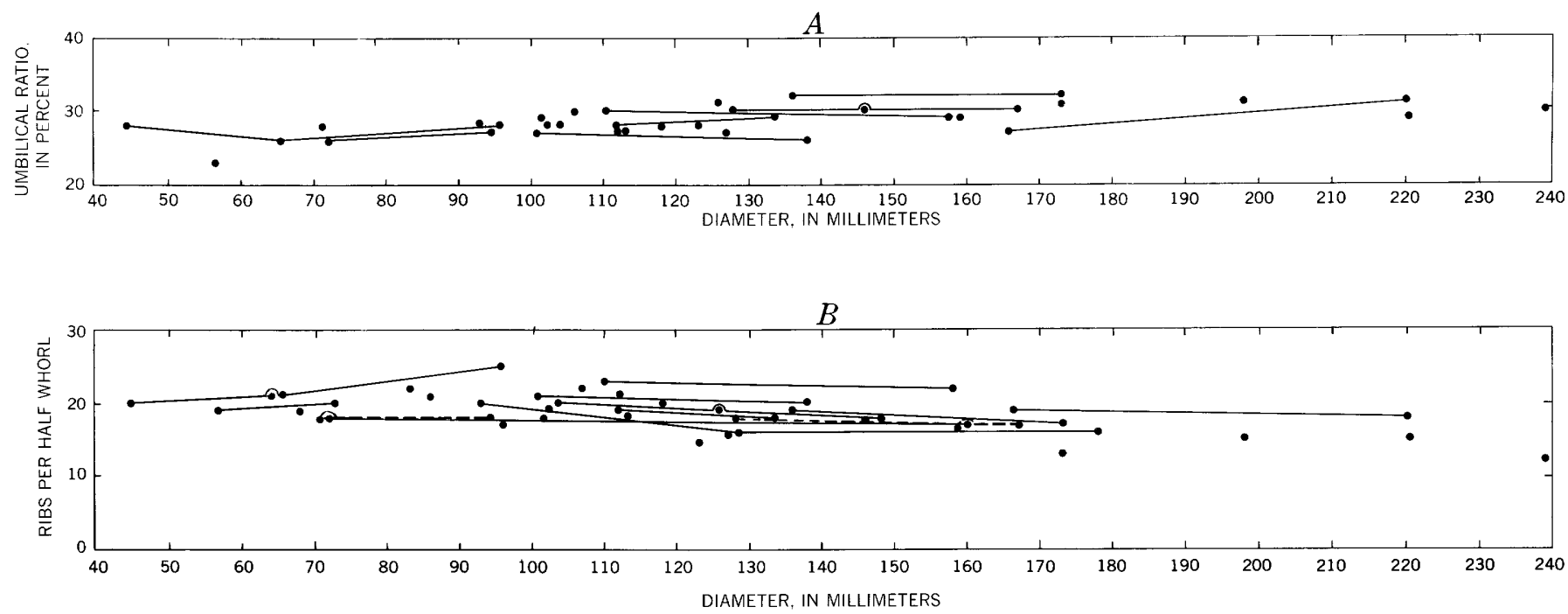

FIgURE 12.-Sicatter diagrams showing umbilical ratios in percent $(A)$ and number of ribs in half a whorl $(B)$ of $C a l y c o c e r a s$ naviculare (Mantell) from the basal bed of the Bridge Creek Limestone Member of the Greenhorn Limestone at USGS Mesozoic localities 18676, 18678, 18683, 18686, 22899, and D6530 (fig. 1, locs. 19-21, 24, 26, 27). Dots connected by lines represent measurements on single specimens.

Ribbing is conspicuous on all specimens. It is rectiradiate on juveniles and slightly rursiradiate on adults. The ribs are strong, rounded, and as wide as, or a little narrower than, the interspaces. They number 12 to 25 per half whorl but the number tends to decrease as the shell enlarges (fig. $12 B$ ). Most specimens have rib counts between 15 and 22 . The ribs are as strong on the venter as on the flank. Every other rib ordinarily begins at the umbilical seam, rapidly increases in height on crossing the umbilical wall, and forms a sharply rounded tubercle on the umbilical shoulder. This primary rib then continues straight across the flank and venter. At or near the beginning of the flank, a secondary rib arises between adjacent primaries and becomes as strong as the primaries before crossing the venter. On a very few individuals, two secondaries may be present between a pair of primaries on some part of the shell (pl. 12, fig. 1 ; pl. 13 , fig. 2). More commonly, at some diameter between 100 and $120 \mathrm{~mm}$, a primary rib on one side will become a secondary rib on the opposite side, and all subsequently formed ribs will behave in this manner (pl. 16, fig. 1). A similar rib arrangement is visible on the rear view of Acanthocenas [Calycoceras] borgesi Douvillé (1931, pl. 2, fig. 3b).

Beginning at a diameter between 85 and $90 \mathrm{~mm}$, each rib on some specimens becomes slightly raised at the ventrolateral margin as though a tubercle was about to form. On these specimens the ribs flatten a little on crossing the venter, and this character combined with the incipient tubercle produces a distinct angularity to the costal whorl section (pl. 11, fig. 5; text fig. 13E). A similar feature apparently was observed on some of the European examples of $C$. naviculare by Matsumoto $(1959$, spec. v. 1 , p. 81$)$ who noted that "On the outer whorl of $C$. naviculare $* * *$ sometimes the ventrolateral tubercles are rejuvenated."

Only one specimen (hypotype USNM 166394, diameter of $198 \mathrm{~mm}$ ) reveals part of the adult aperture, but not enough of it remains to show its shape. The last three ribs are crowded a little, and each may have extended to the umbilical seam.

Bits of the suture are preserved on very few specimens. Figure 14 shows the lateral lobe on one individual. It is broad and little incised and resembles the lateral lobe of the suture figured by Karrenberg (1935, text fig. 1).

Types.-Hypotypes USNM 166362-166394.

Occurrences. - Calycoceras naviculare has been found in the western interior of the United States only in southeastern Colorado and southwestern Kansas (fig. 1 , locs. 16-28, 30). It occurs at or near the base of the

Figure 13.-Cross sections of whorls, natural size, of Calycoceras naviculare (Mantell). A, USNM 166367 at diameter of about $139 \mathrm{~mm}$ (pl. 15, figs. 1, 2). B, USNM 166393 at diameter of $105 \mathrm{~mm}$. $C$, USNM 166378 at diameter of $86 \mathrm{~mm}$ (pl. 13 , figs. $1-3$ ). $D$, USNM 166373 at diameter of $128 \mathrm{~mm}$ (pl. 10 , fig. 8 ; pl. 11, figs. 4,5 ). $E$, USNM 1663891 at diameter of about $140 \mathrm{~mm} . F$. USNM 166372 at diameter of $75 \mathrm{~mm}$. $G$, USNM 166380 (pl. 10, figs. 3, 5). H, USNM 166366 at diameter of 183 mm (pl. 17). 
SYSTEMATIC DESCRIPTIONS

17
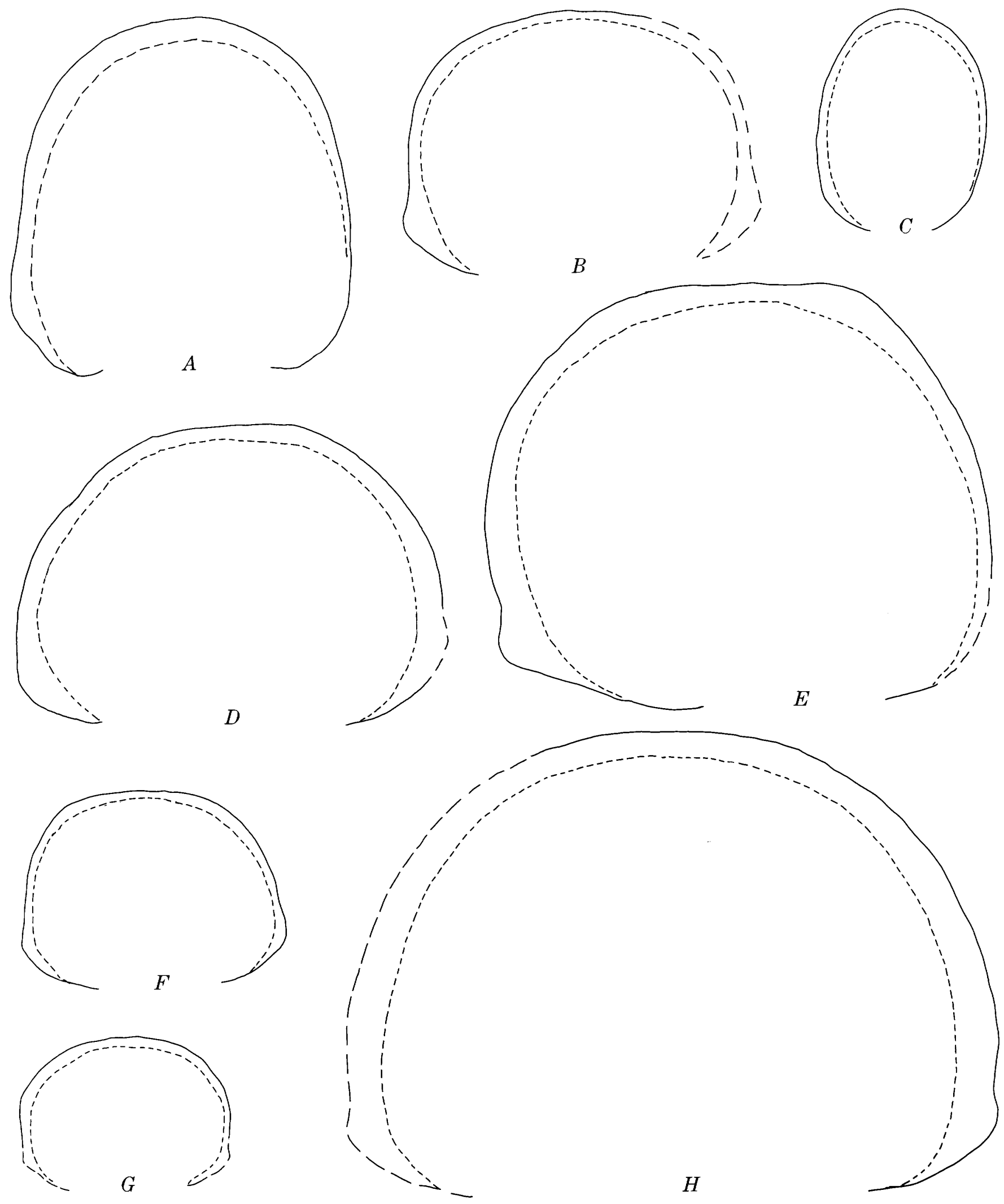

F'toure 13.- (Explanation on opposite page.) 


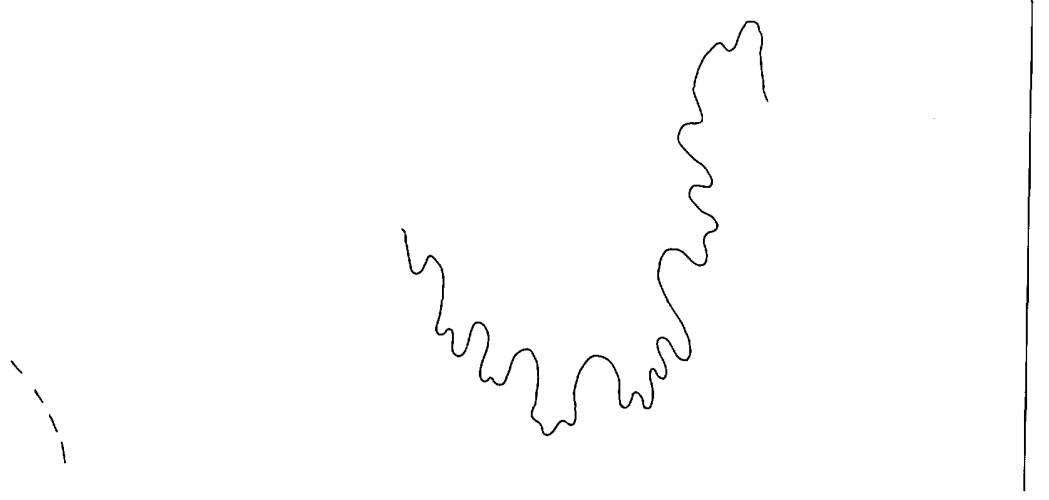

Figure 14.-Lateral lobe, $\times 2$, at a diameter of $73 \mathrm{~mm}$ of the specimen of Calycoceras naviculare (Mantell) shown on plate 10, figure 6. Arrow marks the middle of the venter; dashes mark the umbilical seam. Hypotype USNM 166372.

Bridge Creek Limestone Member of the Greenhorn Limestone. Associated fossils, of very late Cenomanian age, include Inoceramus pictus (J. de C. Sowerby), Sciponoceras gracile (Shumard), Pseudocalycoceras dentonense (Moreman), Kanabiceras septemseriatum. (Cragin), and Metoicoceras whitei Hyatt.

Family VASCOCERATIDAE

Genus NIGERICERAS Schneegans, 1943

Type species.-Nigericeras gignouxi Schneegans, 1943.

There is some question regarding the date of Schneegans' genus. Schneegans (1943, p. 118) gave the date as 1939 , but he did not list a reference of that date in his bibliography. I have not succeeded in finding such a reference. Schneegans' (1934) earlier work reported briefly on these fossils, but the new genus was not proposed at that time. Until the source of the 1939 date is determined, I am following Wright (1957, p. L418) in assuming that Schneegans' 1943 report is the source of the name.

Nigericeras was proposed for ammonites that seem transitional from Acanthoceras to Vascoceras. Inner whorls are ribbed and typically acanthoceratid and have umbilical, lower and upper ventrolateral, and siphonal tubercles. On the adult body chamber, the ribs become greatly weakened or disappear, and the ventrolateral and siphonal tubercles disappear. The suture resembles that of both Acanthoceras and Vascoceras.

The genus is known only from lower Turonian strata, and most records are from Nigeria and Niger. Outside of Africa, the genus has been recorded from Israel
(Freund and Raab, 1969, p. 19) and Turkestan (Reyment, 1955, p. 62).

Nigericeras scotti Cobban, n. sp.

Plate 9, figures 1-4; plate 18, figures 1-9; text figures 15-17

The type collection, from USGS Mesozoic locality D6756 (fig. 1, loc. 29), consists of 26 specimens suitable for measurement and as many more that are too crushed or distorted for measurement. All are internal molds, and most have one side partially or completely dissolved. The innermost whorls are not preserved. Measurements of the best specimens are given in table 3.

TABLE 3.-Dimensions and tubercle counts of Nigericeras scotti, n. sp., from USGS Mesozoic locality D6756

\begin{tabular}{|c|c|c|c|c|c|}
\hline $\begin{array}{l}\text { U.S.N.M. } \\
\text { No. }\end{array}$ & $\begin{array}{c}\text { Diameter } \\
(\mathrm{mm})\end{array}$ & $\begin{array}{c}\text { Umbilical } \\
\text { width (mm) }\end{array}$ & $\begin{array}{l}\text { Umbilical } \\
\text { ratio }\end{array}$ & $\begin{array}{l}\text { Diameter } \\
\text { at base of } \\
\text { body } \\
\text { chamber } \\
(\mathrm{mm})\end{array}$ & $\begin{array}{c}\text { Umbilical } \\
\text { tubercles } \\
\text { per half } \\
\text { whorl }\end{array}$ \\
\hline 166397 . & 32.2 & 6.7 & 0.21 & & \\
\hline 166398 & 39.6 & 13.2 & .33 & & 5 \\
\hline 166399 & 49.0 & 13.8 & .28 & & 5 \\
\hline 166400 & 54.2 & 15.8 & .29 & ... & 6 \\
\hline $166401 \ldots$ & ca .56 & ca .14 & ca. .25 & & 5 \\
\hline 166402 & $\begin{array}{l}60.7 \\
75.0\end{array}$ & $\begin{array}{l}12.8 \\
22.4\end{array}$ & $\begin{array}{l}.21 \\
.30\end{array}$ & & 4 \\
\hline 166403 & 65.3 & 20.5 & 31 & 63 & 3 \\
\hline 166404 & 69.0 & 23.5 & .34 & 69 & 6 \\
\hline 166396 & 69.5 & 21.4 & .31 & 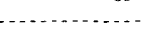 & 6 \\
\hline & 89.4 & 28.2 & .32 & & 7 \\
\hline 166405 & 72.5 & 22.0 & .30 & ca. 72 & 5 \\
\hline 166406 & 75.6 & 25.8 & .34 & .......... & 5 \\
\hline 166407 - & 76.3 & 24.2 & .32 & & 4 \\
\hline $166408 \ldots$ & 77.4 & 23.8 & .31 & 69 & 5 \\
\hline \multirow[t]{2}{*}{166409} & 78.1 & 25.0 & .32 & & 4 \\
\hline & 98.4 & 35.8 & .36 & ca. 69 & \\
\hline \multirow{3}{*}{$166411 \ldots$} & 83.0 & 23.4 & .28 & 74 & 6 \\
\hline & 83.8 & 25.9 & .31 & $\ldots$ & 6 \\
\hline & 115.5 & 38.4 & .33 & & \\
\hline 166412 & 92.3 & 29.4 & .32 & & \\
\hline 166413 & 93.0 & 30.5 & .33 & & \\
\hline 166414 & 94.3 & 32.3 & .34 & & 5 \\
\hline $166415 \ldots$ & 94.5 & 31.8 & .34 & ca. 70 & \\
\hline 166416 & 95.0 & 32.7 & .34 & ca. 62 & \\
\hline 166517 & 101.3 & 35.5 & .35 & . & . \\
\hline $166518 \ldots$ & 109.0 & 38. 0 & .35 & , & \\
\hline 166519 & 112.0 & 37.3 & .33 & & \\
\hline $166520 \ldots$ & 115.7 & 39.2 & .34 & & \\
\hline
\end{tabular}




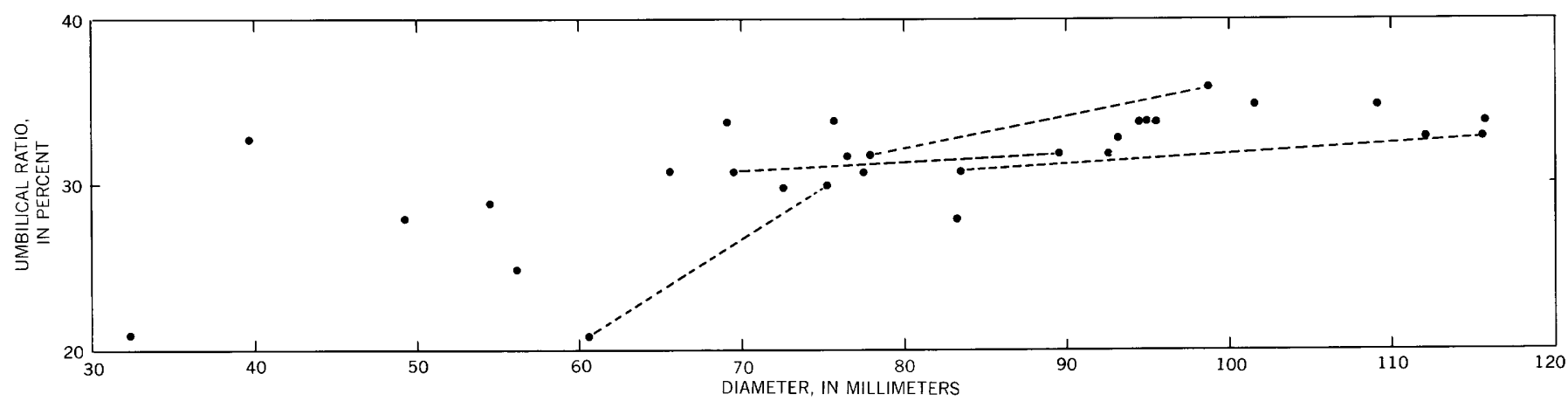

FIgURE 15.-Scatter diagram showing umbilical ratios of Nigericeras scotti, n. sp., from USGS Mesozoic locality D6756. Dots connected by dashes represent measurements on single specimens.

Umbilical ratios range from 21 to 36 percent and show a gradual increase with growth of the shell up to the base of the body chamber (fig. 15). The ratio then increases a little more rapidly owing to a slight scaphitoid development of the adult body chamber (pl. 18, fig. 9).

Whorl sections are very stout; most are a little higher than wide, but some are as wide as high (fig. 16).

Ornamentation consists of rectiradiate ribs and umbilical tubercles, lower and upper ventrolateral tubercles, and siphonal tubercles, all of which are most conspicuous on the phragmocone. The ribs are rather widely spaced and consist of primaries and secondaries that tend to vary in size and strength. The primaries rise from umbilical tubercles, weaken on crossing the
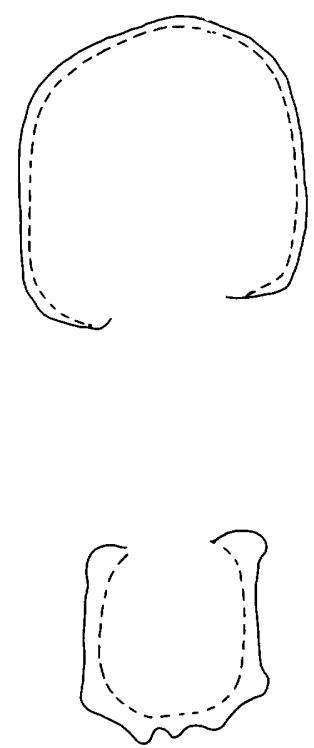

FrgurE 16.-Whorl sections, natural size, of the holotype of Nigericeras scotti, $\mathrm{n}$. sp., at a diameter of $74 \mathrm{~mm}$. USNM 166396. flank, and become strong again on crossing the venter. On the smallest specimen (diameters between 22 and $33 \mathrm{~mm}$ ), most adjacent primaries are separated by two secondaries. The secondary ribs rise on the middle of the flank and on some individuals become on the venter as strong as the primaries. All ribs weaken on the body chamber, and some disappear from the flanks. Each primary rib on the phragmocone bears a strong nodate lower ventrolateral tubercle, a smaller nodate, bullate, or clavate upper ventrolateral tubercle, and a still smaller clavate siphonal tubercle.

Most secondary ribs on the phragmocone have upper ventrolateral tubercles and siphonal tubercles; some secondaries rising lower on the flank have, in addition, nodate lower ventrolateral tubercles. All tubercles weaken near the end of the adult phragmocone and disappear well down on the body chamber.

The body chamber begins at some diameter between 62 and $76 \mathrm{~mm}$ (table 3). Its cross section is inflated with flattened to broadly rounded flanks and well-rounded venter. Most specimens show a little straightening of the older part of the body chamber which imparts to it a slight scaphitoid appearance (pl. 18, fig. 9). The aperture seems to be smooth, straight, and not constricted (pl. 18, fig. 8). The entire body chamber occupies a little more than half a whorl.

A complete external suture is not preserved on any of the specimens. The few bits of visible sutures are poorly preserved. Parts of sutures of five individuals are shown in figure 17. These reveal a rather simple pattern with high and narrow first lateral saddle and broad deeply bifid lateral lobe.

The holotype (pl. 9, figs. 1-4; text fig. 16) consists of most of an adult; it is $90 \mathrm{~mm}$ in diameter and has umbilical ratios of 31 and 32 percent. It is distorted a 

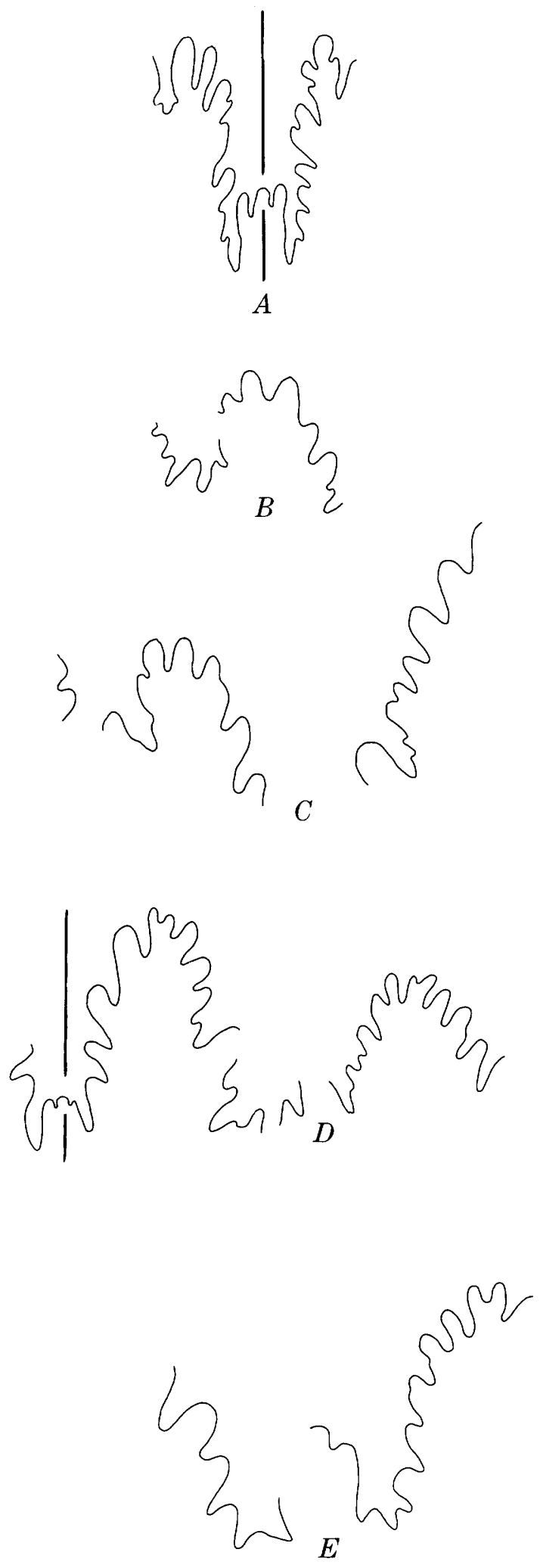

Figure 17.-Parts of external sutures, $\times 3$, of five specimens of Nigericeras scotti, n. sp. A, Siphona,l lobe of paratype USNM 166410 at diameter of $49 \mathrm{~mm}$. $B$, Second lateral saddle and second lateral lobe of paratype USNM 166416 at diameter of $52 \mathrm{~mm}$. $C$, Part of lateral lobe, second lateral saddle, and second lateral lobe of paratype USNM 166521 at diameter of about $44 \mathrm{~mm}$. D, Paratype USNM 166522. $E$, Lateral lobe of paratype USNM 166520 at diameter of $60 \mathrm{~mm}$.

little but shows the main features of the species. The last whorl has a maximum height of $38.5 \mathrm{~mm}$ and a width of $31 \mathrm{~mm}$.

The species is named for Glenn R. Scott, of the U.S. Geological Survey, who made the original collection.

Nigericeras scotti more closely resembles the acanthoceratid forms of the genus than the vascoceratid forms. It perhaps most closely resembles $N$. ogojaense Reyment (1955, p. 62, pl. 13, fig. 6 ; pl. 14, fig. 3 ; text fig. 28$)$ in the persistence of acanthoceratid ornamentation out to a large diameter and in the deeply bifid lateral lobe, but the Nigerian species has the ventrolateral tubercles remaining at greater diameters, as well as occurring in pairs. Of the species from the Damergou area in Niger, the one most closely resembling $N$. scotti is $N$. gignouxi Schneegans (1943, p. 119, pl. 5, figs. 10-15; text figs. 1, 2; Furon, 1935, p. 56, pl. 2, fig. 9 only) which has coarsely sculptured inner whorls, but that ornamentation disappears at a smaller diameter, the adult body chamber lacks the scaphitoid development, and the first lateral saddle is broader. Other species from Niger and Nigeria, such as $N$. gadeni (Chudeau, 1909, p. 71, pl. 3, figs. $6 \mathrm{a}, \mathrm{b} ; 1921$, p. 468 , text figs. 4,5 ) and the species described by Barber (1957, p. 29-31), have the inner whorls more weakly sculptured and more rounded, and the sutures more simplified.

Types.-Holotype USNM 166396 ; paratypes USNM 166397-166416, 166517-166522, 164057.

Occurrence.-Nigericeras scotti has been found at only one locality in southeastern Colorado (fig. 1, loc. 29), where it occurs in a thin bed of limestone about 12 feet above the base of the Bridge Creek Limestone Member of the Greenhorn Limestone. It was associated with a few poorly preserved inocerams that could represent Inoceramus labiatus (Schlotheim) at the base of the Turonian.

\section{REFERENCES CITED}

Anderson, F. M., 1902, Cretaceous deposits of the Pacific coast: California Acad. Sci. Proc., 3d ser., Geology, v. 2, no. 1, p. 1-154, pls. 1-12.

1958, Upper Cretaceous of the Pacific coast: Geol. Soc. America Mem. 71, 378 p., 75 pls.

Barber, W., 1957, Lower Turonian ammonites from northeastern Nigeria : Nigeria Geol. Survey Bull. 26, 67 p., 34 pls.

Böse, Emil, 1910, Monographía geológica y paleontológica del Cerro de Muleros cerca de ciudad Juárez, Estado de 
Chihuahua, $\boldsymbol{y}$ descripción de la fauna cretácea de la Encantada, placer de Guadalupe, Estado de Chihuahua: Inst. Geol. México Bol. 25, 193 p., 48 pls.

Boule, Marcellin, Lemoine, Paul, and Thevenin, Armand, 1906-7, Céphalopodes crétacés des environs de Diégo-Suarez [Madagascar]: Annales Paléontologie, v. 1, pt. 4 (1906), p. $173-192$, pls. $14-20$; v. 2, pt. 1 (1907), p. 1-56, pls. $1-8$.

Brauns, D., 1875, Die senonen Mergel des Salzbergs bei Quedlinburg: Zeitschr. Gesammten Naturw., v. 46 (n. ser., v. 12), p. $325-420$, pls. $7-10$.

Brobst, D. A., 1961, Geology of the Dewey quadrangle, Wyoming-South Dakota: U.S. Geol. Survey Bull. 1063-B, p. $13-60$, pls. 5, 6

Brobst, D. A., and Epstein, J. B., 1963, Geology of the Fanny Peak quadrangle, Wyoming-South Dakota: U.S. Geol. Survey Bu,ll. 1063-I, p. 323-377, pls. 25-26.

Choffat, Paul, 1898, Les Ammonées du Bellasien, des couches à Neolobites vibrayeanus, du Turonien et du Sénonien, Part 2 of Recueil d'études paléontologiques sur la faune crétacique du Portugal: Lisbonne, Acad. Royale Sci., v. 1, 2d ser., p. 41-86, pls. 3-22.

Chudeau, René, 1909, Ammonites du Damergou (Sahara méridional) : Soc. Géol. France Bull., sér. 4, v. 9, p. 67-71, pls. $1-3$.

1921, Ammonites turoniennes du Soudan: Mus. Natl. Histoire Nat. Bull., Année 1921, no. 6, p. 463-470.

Cieśliński, Stefan, 1959, Alb i cenoman polnocnego obrżezenia Gór Swiętokrzyskich (stratygrafia na podstawie glowonogow) [The Albian and Cenomanian in the northern periphery of the Święty Krzyż Mountains] [includes Russian and English summs.] : [Poland] Inst. Geol. Prace, v. 28,95 p., 8 pls.

Cobban, W. A., 1951, Colorado shale of central and northwestern Montana and equivalent rocks of Black Hills: Am. Assoc. Petroleum Geologists Bu,ll., v. 35, no. 10, p. 2170-2198.

Collignon, Maurice, 1931, La faune du Cénomianien a fossiles pyroteux du nord de Madagascar, Part 16 of Paléontologie de Madagascar: Annales Paléontologie, v. 20, pt. 2, p. 43104, pls. 5-9.

— 1937, Ammonites cénomaniennes du sud-ouest de Madagascar: Madagascar, Service Mines, Annales Géol., pt. 8, p. 31-69, pls. 1-11.

1964, Atlas des fossiles caractéristiques de Madagascar (ammonites), Part 11, Cenomanien: Republique Malgache Service Géol., Tananarive, 152 p., pls. 318-375.

1965, Nouvelles ammonites néocrétacées sahariennes: Annales Paléontologie, v. 51, pt. 2, p. 165-202, pls. A-H. 1966, Atlas des fossiles caractéristiques de Madagascar (ammonites), Part 14, Santonien: Republique Malgache Service Géol., Tananarive, 134 p., pls. 455-513.

Crick, G. O., 1919, On Ammonites navicularis, Mantell : Malacological Soc. London Proc., v. 13, p. 154-160, pl. 4.

Douvillé, Henri, 1931, Les ammonites de Salinas, in Contribution a la géologie de l'Angola : Lisboa Univ. Mus. e Lab. Mineral. Geol. Bol., ser. 1, v. 1, no. 1, p. 17-46, pls. 1-4.

Freund, Raphael, and Raab, Menahem, 1969, Lower Turonian ammonites from Israel: Palaeont. Assoc. London Spec. Paper 4, 83 p., 10 pls.

Furon, Raymond, 1935, Le Crétacé et le Tertiaire du Sahara soudanais (Soudan, Niger, Tchad): Mus. Natl. Histoire Nat. Archives, 6th ser., v. 13, p. 1-96, pls. 1-7.

Grossouvre, Albert de, 1893, Les ammonites de la craie supérieure, Part 2, Paléontologie, of Recherches sur la craie supérieure: Carte Géol. Détaillée France Mém., 264 p., 39 pls. [1894].
1912, Le Crétacé de la Loire-Inférieure et de la Vendée : Soc. Sci. Nat. l'Ouest France Bull., 3d ser., v. 2, p. 1-38, pls. 1-3.

Hyatt, Alpheus, 1903, Pseudoceratites of the Cretaceous, edited by T. W. Stanton: U.S. Geol. Survey Mon. 44, 351 p., 47 pls.

Karrenberg, Herbert, 1935, Ammonitenfaunen aus der nordspanischen Oberkreide: Palaeontographica, v. 82, pt. A, nos. 4-6, p. 125-161, pls. 30-33.

Laube, G. C., and Bruder, Georg, 1887, Ammoniten der böhmischen Kreide: Palaeontographica, v. 33, p. 217-239, pls. 23-29.

Leonhard, Richard, 1897, Die Fauna der Kreideformation in Oberschlesien: Palaeontographica, v. 44, p. 11-70, pls. 3-6.

Mantell, Gideon, 1822, The fossils of the South Downs or illustrations of the geology of Sussex: London, Lupton Relfe, 327 p., 42 pls.

Mapel, W. J., and Pillmore, C. L., 1963a, Geology of the Inyan Kara Mountain quadrangle, Crook and Weston Counties, Wyoming: U.S. Geol. Survey Bull. 1121-M, p. M1-M56, illus.

$1963 \mathrm{~b}$, Geology of the Newcastle area, Weston County, Wyoming: U.S. Geol. Survey Bull. 1141-N, p. N1-N85, illus.

Matsumoto, Tatsuro, 1953, Selected Cretaceous leading ammonites in Hokkaido and Saghalien, in Matsumoto, Tatsuro, chm., The Cretaceous system in the Japanese islands : Tokyo, Japan Soc. Promotion Sci. Research, p. 243-313, pls. 17-36.

_- 1954, Family Puzosidae from Hokkaido and Saghalien (Studies on the Cretaceous Ammonoidea from Hokkaido and Saghalien-V) : Kyushu Univ. Fac. Sci. Mem., Ser. D, Geology, v. 5, no. 2, p. 69-118, pls. 9-23.

1959, Zonation of the Upper Cretaceous in Japan : Kyushu Univ. Fac. Sci. Mem., Ser. D, Geology, v. 9, no. 2, p. 55-93, pls. 6-11.

1959-60, Upper Cretaceous ammonites of California : Kyushu Univ. Fac. Sci. Mem., Ser. D, Geology, pt. 1, v. 8, no. 4 , p. $91-171$, pls. $30-45$ (1959) ; pt. 2, spec. v. 1,172 p., 41 pls. (1959) ; pt. 3, spec. v. 2, 204 p., 2 pls. (1960).

1960, On some type ammonites from the Gulf Coast Cretaceous [in Japanese]: Kyushu Univ. Fac. Sci., Sci. Rept., Geology, v. 5, no. 1, p. 36-49.

Matsumoto, Tatsuro, Saito, Rinji, and Fukada, Atsuo, 1957, Some acanthoceratids from Hokkaido (Studies on the Cretaceous ammonites from Hokkaido and Saghalien-XI) : Kyushu Univ. Fac. Sci. Mem., Ser. D, Geology, v. 6, no. 1, p. $1-45,18 \mathrm{pls}$.

Michelin, Hardouin, 1838, Note sur une argile dépandant du Gault, observée au Gaty, Commune de Gérodot, Département de l'Aube: Soc. Géol. France Mém., ser. 1, v. 3, pt. 1, no. 5, p. 97-103, pl. 12.

Moench, R. H., 1963, Geologic map of the Laguna quadrangle, New Mexico: U.S. Geol. Survey Geol. Quad. Map GQ-208.

Moreman, W. L., 1927, Fossil zones of the Eagle Ford of north Texas: Jour. Paleontology, v. 1, no. 1, p. 89-101, pls. 13-16. ___ 1942, Paleontology of the Eagle Ford group of north and central Texas: Jour. Paleontology, v. 16, no. 2, p. 192-220, pls. 31-34.

Morrow, A. L., 1935, Cephalopods from the Upper Cretaceous of Kansas: Jour. Paleontology, v. 9, no. 6, p. 463-473, pls. $49-53$.

Neumayr, M., 1875, Die Ammoniten der Kreide und die Systematik der Ammonitiden: Deutsch. Geol. Gesell. Zeitschr. v. 27, p. $854-942$.

$\emptyset_{\mathrm{dum}}$, Hilmar, 1953, The macro-fossils of the Upper Cretaceous, Part 5 of De geologiska resultaten från borrningarna vid Höllviken: Sveriges Geol. Undersökning Ărsb. 46, no. 3, Ser. C, no. 527, 37 p., 4 pls. 
Orbigny, Alcide d', 1840-42, Céphalopodes-Paléontologie française, terrain Crétacé : Paris, Masson et Cie, ser. 1, v. 1, $662 \mathrm{p} ., 148 \mathrm{pls}$.

1850-52, Prodrome de paléontologie stratigraphique universelle des animaux mollusques et rayonnés, v. 2 : Paris, V. Masson, $428 \mathrm{p}$.

Pervinquière, Léon, 1907. Études de paléontologie tunisienne, Part 1, Céphalopodes des terrains secondaires: Carte Géol. Tunisie, 438 p., 27 pls.

Pictet, F. J., 1854, Traité de paléontologie ou histoire naturelle des animaux fossiles [2d ed.], v. 2: Paris, Chez J.-B. Baillière, $727 \mathrm{p}$.

1863, Discussion sur les variations et les limites des quelques espèces d'Ammonites du groupe des $A$. rotomagensis et mantelli; Soc. Phys. et Histoire Nat. Genève Mém. v. 17, pt. 1, p. 34-58, pls. 1-7.

Pictet, F. J., and Roux, William, 1847, Description des mollusques fossiles, qui se trouvent dans les grès verts des environs de Genève: Soc. Phys. et Histoire Nat. Genève Mém., v. 11, pt. 2, p. 257-412, pls. 1-15.

Reyment, R. A., 1954, Some new Upper Cretaceous ammonites from Nigeria: Colonial Geology and Mineral Resources, v. 4 , no. 3, p. 248-270, 5 pls.

1955, The Cretaceous Ammonoidea of southern Nigeria and the southern Cameroons: Nigeria Geol. Survey Bull. 25,112 p., 25 pls.

Riedel, Leonard, 1931, Zur Stratigraphie und Faciesbildung im Oberemscher und Untersenon am Südrande des Beckens von Münster: Preuss. Geol. Landesanst. Jahrb., v. 51, pt. 2, p. 605-713, pls. 72-79.

Robinson, C. S., Mapel, W. J., and Bergendahl, M. H., 1964, Stratigraphy and structure of the northern and western flanks of the Black Hills uplift, Wyoming, Montana, and South Dakota: U.S. Geol. Survey Prof. Paper 404, 134 p., 5 pls.

Sacco, Federico, 1893, Contribution a la connaissance paléonItologique des argiles écailleuses et des schistes ophiolitiques de l'Apennin septentrional: Soc. Belge Géologie, Paléontologie et Hydrologie Mém., v. 7, p. 1-34, pls. 1, 2.

Salfeld, Hans, 1919, Über die Ausgestaltung der Lobenlinie bei Jura- und Kreide-Ammonoideen: Kgl. Gesell. Wiss. Göttingen Nachr., Math.-Phys. Kl. 1919, no. 3, p. 449-467.

Sastry, M. V. A., Rao, B. R. J., and Mamgain, V. D., 1968, Biostratigraphic zonation of the Upper Cretaceous formations of Trichinopoly District, South India, in Cretaceous-Tertiary formations of South India: Geol. Soc. India, Mem. 2, p. $10-17,4$ pls.

Schlthter, Clemens, 1867, Ammoniten der Senon-Bildung, Part 1 of Beitrag zur Kenntnis der jüngsten Ammoneen Norddeutschlands: Bonn, A. Henry, 36 p., 6 pls.

-1871-72, 1876, Cephalopoden der oberen deutschen Kreide : Palaeontographica, v. 21 (1871-72), p. 1-120, pls. 1-35; v. 24 (1876), p. 121-264, pls. 36-55.

Schneegans, D., 1934, Etude paléontologique préliminaire des fossiles recueillis par R. Lambert entre Agadez et Zinder (Niger) : Acad. Sci. Comptes Rendus, v. 198, p. 2191-2193.

— 1943, Invertébrés du Crétacé supérieur du Damergou (Territoire du Niger); with a Note sur les Echinides de Marma, by J. Lambert, in Études stratigraphiques et paléontologiques sur le Bassin du Niger : French West Africa Direction Mines Bull. 7, p. 87-150, 8 pls.

Sharpe, Daniel, 1853-56, Description of the fossil remains of Mollusca found in the Chalk of England: Palaeont. Soc.
[Mon.], 68 p., 27 pls. (p. 1-26, pls. $1-10,1853$; p. 27-36, pls. 11-16, 1854 [1855] ; p. 37-68, pls. 17-27, 1856 [1857]).

Sowerby, James, 1818-21, The mineral conchology of Great Britain, v. 3 : London, W. Arding, 1818, p. 1-40, pls. 204-221; 1819 , p. $41-98$, pls. $222-253$; 1820, p. 99-126, pls. 254-271: 1821 , p. $127-184$, pls. $272-306$.

Sowerby, J. de C., 1823-29, The mineral conchology of Great Britain: London, B. Meredith, 1823, v. 4, p. 115-148, pls. $384-407$, v. 5 , p. $1-64$, pls. $408-443 ; 1824$, v. 5, p. $65-138$, pls. $444-485 ; 1825$, v. 5 , p. $139-168$, pls. $486-503 ; 1826$, v. 6 , p $1-86$, pls. 504-545; 1827 , v. 6, p. 87-156, pls. 546-580; 1828. v. 6 , p. $157-200$, pls. $581-597 ; 1829$, v. 6 , p. $201-230$, pls. 598-609.

Spath, L. F., 1921, On Cretaceous Cephalopoda from Zululand: South African Mus. Annals, v. 12, pt. 7, no. 16, p. 217-321. pls. 19-26.

1922, On the Senonian ammonite fauna of Pondoland: Royal Soc. South Africa Trans., v. 10, pt. 3, p. 113-147, pls. $5-9$.

1923-43, A monograph of the Ammonoidea of the Gault [Cretaceous] : Palaeont. Soc. Mon., 787 p., 72 pls. [16 pts.]. 1926a, On new ammonites from the English Chalk: Geol. Mag., v. 63, no. 740, p. 77-83.

$-1926 \mathrm{~b}$, On the zones of the Cenomanian and the uppermast Albian: Geologists' Assoc. [London] Proc., v. 37, pt. 4, p. 420-432.

1937, The nomenclature of some lower Chalk ammonites: Geol. Mag., v. 74, no. 6, p. 277-281.

Stoliczka, Ferdinand, 1865, The fossil Cephalopoda of the Cretaceous rocks of southern India (Ammonitidae) : India Geol. Survey Mem., Palaeontologia Indica, p. 41-216, pls. 26-94.

Stolley, E., 1916, Neue Beträge zur Kenntnis der norddeutschen oberen Kreide, I-IV : Niedersächs. Geol. Ver., Geschäftsjahr 1916, p. 69-108, pl. 5.

Strain, W. S., 1968, Cerro de Muleros (Cerro de Cristo Rey) : West Texas Geol. Soc. Guidebook Delaware Basin exploration 1968 , p. 82 .

Wegner, Theodor, 1905, Die Granulatenkreide des westlichen Münsterlandes: Deutsche Geol. Gesell. Zeitschr., v. 57, p. 112-232, pls. 7-10.

Wiedmann, Jost, 1959, Le Crétacé supérieur de l'Espagne et du Portugal et ses Céphalopores, in Collogue Crétacé supérieur français: Soc. Savantes Paris, 84th Cong., Dijon, Sec. Sci., Comptes Rendus Colloque Crétacé, p. 709-764, 8 pls. [1960]. 1964, Le Crétacé supérieur de l'Espagne et du Portugal et ses Céphalopodes: Consejo Superior de Inv. Cientificos, Inst. Inv. Geol. "Lucas Mallada," Estudios Geologicos, v. 20, p. 107-148.

Wright, C. W., 1957, Superfamilies Desmocerataceae [p. L362L381] and Acanthocerataceae [p. L402-L437], in Arkell, W. J., Kummel, Bernhard, and Wright, C. W., Mesozoic Ammonoidea, in Part L of Moore, R. C., ed., Mollusca 4 Treatise on invertebrate paleontology : New York and Lawrence, Kans., Geol. Soc. America and Kansas Univ. Press, 490 p., 558 text figs.

Wright, C. W., and Wright, E. V., 1951, A survey of the fossil Cephalopoda of the Chalk of Great Britain : Palaeont. Soc. [Mon.], $40 \mathrm{p}$.

Zittel, K. A., 1881-85, Handbuch der Palaeontologie, v. 1, pt. 2 : München and Leipzig, R. Oldenbourg, 893 p., illus.

1900, Text-book of palaeontology [C. R. Eastman, ed.] [1st ed.] : London, MacMillan \& Co., 706 p. 


\section{INDEX}

[Italic page numbers indicate both major references and descriptions]

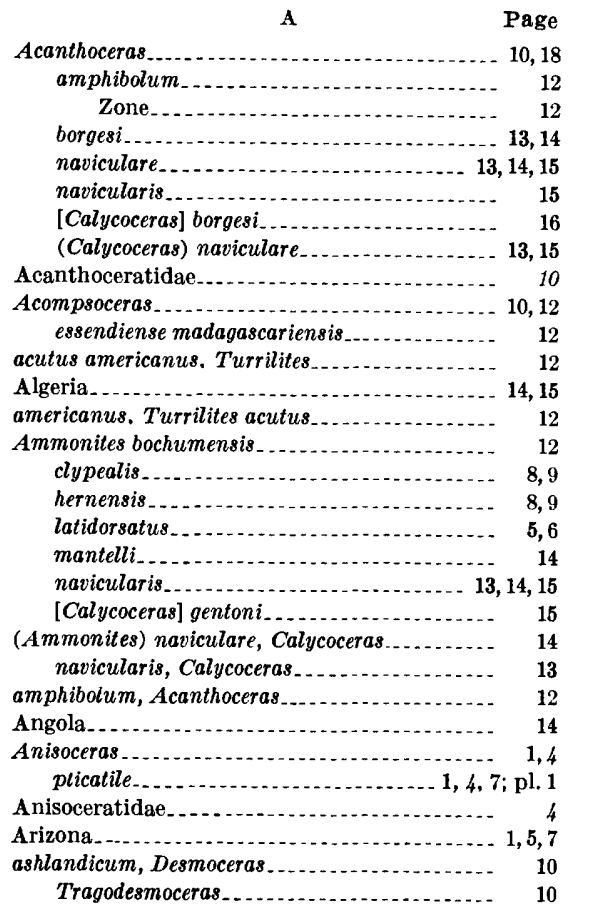

B

bassi, Tragodesmoceras

bererense, Tragodesmoceras-ase-

Bergquist, H. R., cited........

Black Hills..................... 8,10

Black Mesa

bochumensis, Ammonites.

Bohemia............................. 15

Boquillas Formation.................. 13

borgesi, Acanthoceras.......................... 13,14

Acanthoceras [Calycoceras]

Metacalycoceras.

Bridge Creek Limestone Member of the Greenhorn Limestone ... . . . . . 4, 5, 7, 15, 18, 20

Burkholder, Robert E., cited............

Calycoceras ............................. 1,19 grossouvrei. . . . . 13,15

naviculare $\ldots \ldots \ldots \ldots$

7,$18 ;$ pls. $1,10,11,12,13,14,15,16,17$

stoliczkai

(Ammonites) naviculare................. 14

navicularis 13

(Metacalycoceras) naviculare.............

stoliczkai.....

[Calycoceras] borgesi, Acanthoceras........... 16

gentoni, Ammonites

(Calycoceras) naviculare, Acanthoceras. ....... 13, 15

cantianum, Mantelliceras................... 14

Capraro, Charles C., cited................ 1

Carlile Shale .......................... 8,10

carlilense, Tragodesmoceras ........... $8 ;$ pls. $3,4,5$

Cerro de Muleros.

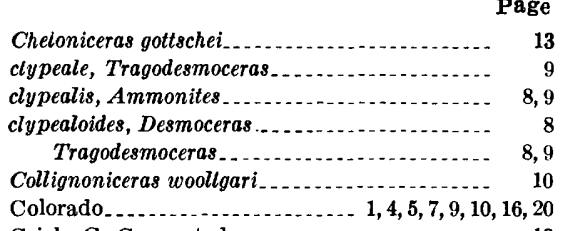

Crick, G. C., quoted.................... 13

dentonense, Pseudocalycocetas .... . . . . . . 5, 7, 18

Desmoceras

ashlandicum . . .

clypealoides ............ 8

kossmati.... 5

latidorsatum ................ 5,6

(Moremanoceras) scotti $\ldots \ldots \ldots, 6$ pl. 2

Desmoceratidae...

Dorset, England.....

$\mathbf{E}$

Eagle Ford Formation.

6

essendiense madagascariensis, Acompsoceras...

\section{F}

Fagesia navicularis

..... $13,14,15$

Fairport Chalky Shale Member of the Carlile Shale..................... 10

$\begin{array}{lr}\text { France } & 8,14 \\ \text { Fukada, Atsuo, quoted } & 13\end{array}$

gadeni, Nigericeras.

gentoni, Ammonites [Calycoceras]

Geographic distribution.

Germany ............. 4, 8,9

gibbosum, Worthoceras.................... 7

gignouxi, Nigericeras

gottschei, Cheloniceras

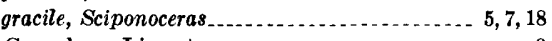

Greenhorn Limestone. . ......... 9

grossouvrei, Calycoceras _. . . . .

Metacalycoceras $\ldots \ldots \ldots$

$\mathbf{H}$

Hamites plicatili saussureanus

Haploceras.

Hauericeras.

hernense, Tragodesmoceras ............... 8,9

hernensis, Ammonites.................... 8,9

India._........... I

Inoceramus labiatus.

pictus................................ 5, 7, 18

Introduction

Israel

Japan

$\mathbf{J}$

\section{K}

Kanabiceras septemseriatum ............. 5, 7,18

Kansas.

kossmati. Desmoceras

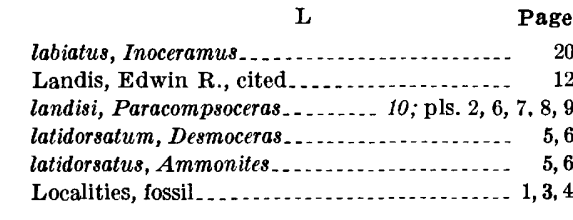

\section{$\mathbf{M}$}

Madagascar................... 4, $4,14,15$ Mancos Shale.......................... 7

second sandstone member. ............. 12

mantelli, Ammonites....................... 14

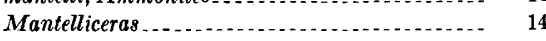

cantianum........................... 14

Matsumoto, Tatsuro, quoted............. 16

Metacalycoceras

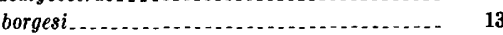

grossouvrei............................ 13, 14

naviculare......................... 13

orbignyi $i_{\ldots} \ldots$

(Metacalycoceras) naviculare, Calycoceras

stoliczkai, Calycoceras. .................. 15

Metoicoceras whitei................. 7,18

Model anticline........................... 4

Moremanoceras_........................... 5

(Moremanoceras) scotti, Desmoceras....... 5, 6; pl. 2

muelleri, Puzosia.............. 8,9

Muniericeras

Muniericeratidae.......................... 8

\section{$\mathrm{N}$}

naviculare, Acanthoceras _.............. 13,14,15

Acanthoceras (Calycoceras) . . . . . . . . . . . . 13, 15

Calycoceras ........... 5 7,13 ; pls. $1,10,11,12,13,14,15,16,17$

(Ammonites)

(Metacalycoceras)

Metacalycoceras.

navicularis, Acanthoceras..................... 15

Ammonites.......................... 13, 14, 15

Calycoceras (Ammonites) ............... 13

Fagesia.................. 13, 14, 15

New Mexico ............................... 1,12

newberryi, Pycnodonte $\ldots . . . . . . . . . . . . . . .7$

Niger .................. 18, 20

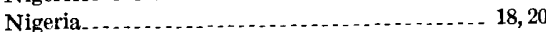

Nigericeras . $\ldots \ldots \ldots \ldots \ldots \ldots \ldots$

gadeni........... 20

gignouxi............ 18, 20

ogojaense_................................ 20

scotti.............. 18; pls. 9,18

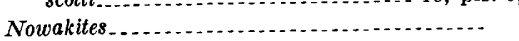

o

ogojaense, Nigericeras...................... 20

Onitshoceras...................................

scotti.

orbıgnyi, Metacalycoceras

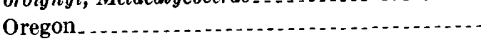

oregonensis, Pachydiscus.

$\mathbf{P}$

Pachydiscus oregonensis sp A 
INDEX

\begin{tabular}{|c|c|}
\hline & $\mathbf{P}$ \\
\hline \multicolumn{2}{|c|}{ Paracompsoceras } \\
\hline \multirow{2}{*}{\multicolumn{2}{|c|}{$\begin{array}{r}\text { landisi } \\
\text { pictus, Inoceramus }\end{array}$}} \\
\hline & \\
\hline \multicolumn{2}{|c|}{ plicatile, Anisoceras. } \\
\hline \multicolumn{2}{|c|}{ plicatilis, Hamites. } \\
\hline \multicolumn{2}{|c|}{ Poland } \\
\hline \multicolumn{2}{|c|}{ Pool Creek Shale Member of the Carlile Shale.. } \\
\hline \multicolumn{2}{|c|}{ Portugal } \\
\hline \multicolumn{2}{|c|}{ Powell, J. Dan, cited........ 12} \\
\hline \multirow{2}{*}{\multicolumn{2}{|c|}{ 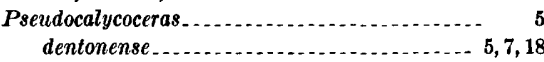 }} \\
\hline & \\
\hline \multicolumn{2}{|c|}{ Puzosia } \\
\hline muelleri.............. & (n) \\
\hline \multicolumn{2}{|c|}{ n. sp } \\
\hline \multicolumn{2}{|c|}{ Puzosinae } \\
\hline \multicolumn{2}{|c|}{ Pycnodonte newberryi............................... } \\
\hline \multicolumn{2}{|r|}{$\mathbf{S}$} \\
\hline Saito, Rinji, quoted. - & 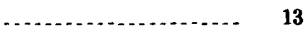 \\
\hline Sarthe, France $\ldots . . . . .$. & . n \\
\hline saussureanus, Hamites. & ......................... \\
\hline Sciponoceras gracile & (n) \\
\hline Scott, Glenn R., cited & 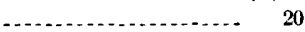 \\
\hline
\end{tabular}

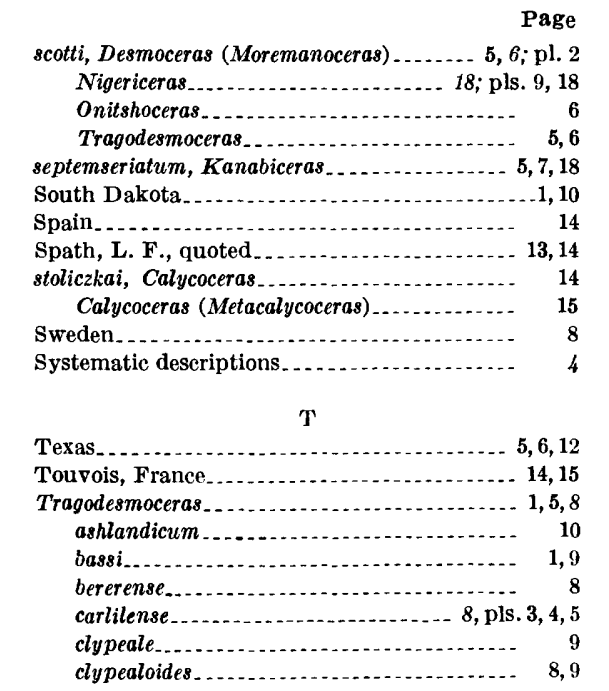

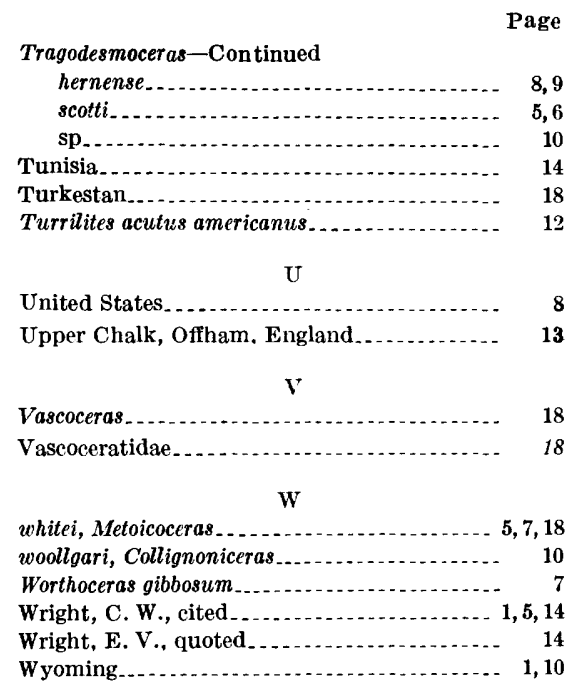




\section{PLATES 1-18}

[Contact photographs of the plates in this report are available, at cost, from U.S. Geological Survey Library, Federal Center, Denver, Colorado 80225] 


\section{PLATE 1}

[All figures natural size]

Figures 1-3. Calycoceras naviculare (Mantell) (p. 13).

Rear, side, and front views of the inner whorls of a specimen from the base of the Bridge Creek Limestone Member of the Greenhorn Limestone at USGS loc. 18686 (text fig. 1, loc. 24). See plate 13, figures 4 and 5 for rest of the specimen. Hypotype USNM 166362.

4-7. Anisoceras plicatile (J. Sowerby) (p. 4).

From the base of the Bridge Creek Limestone Member of the Greenhorn Limestone at USGS loc. 22899 (text fig. 1 loc. 26).

4, 5. Rear and side views of a large limb. Hypotype USNM 166338.

6, 7. Side and rear views of a smaller limb. Hypotype USNM 166337. 


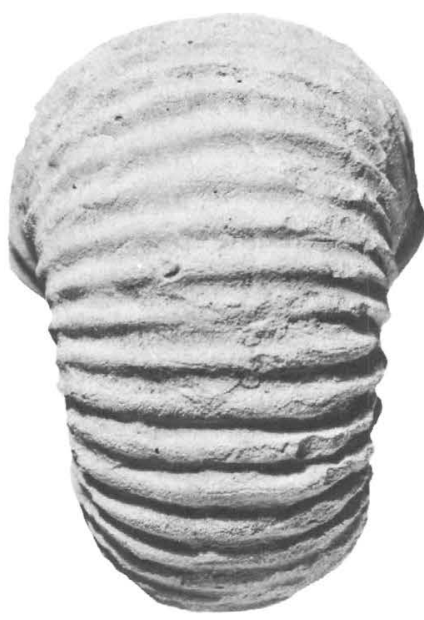

1

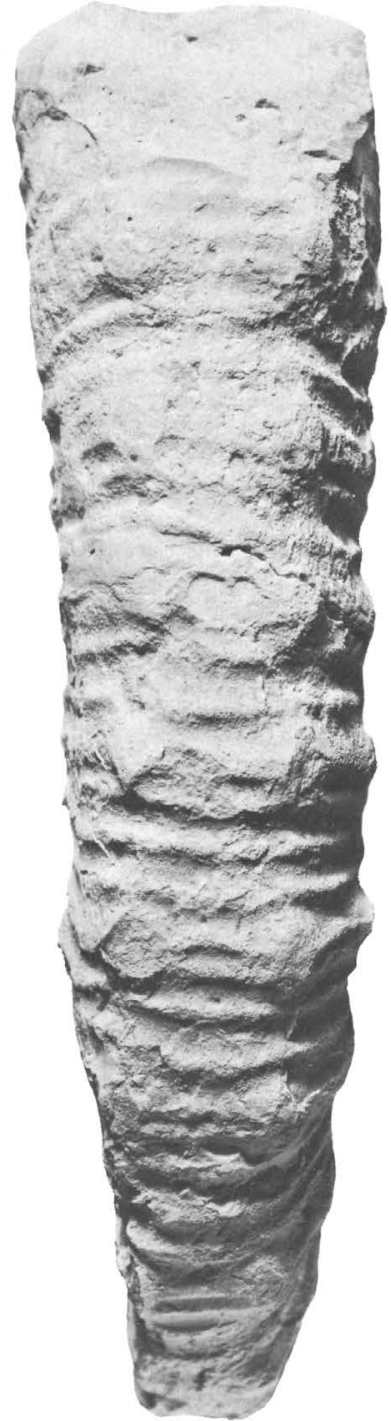

4
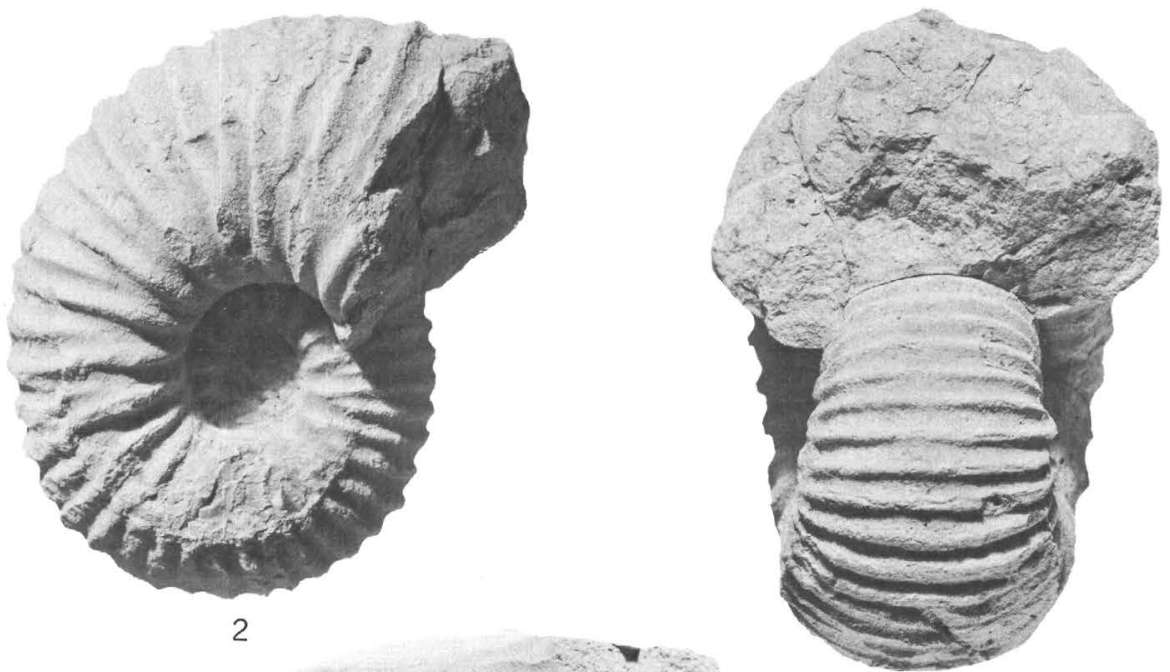

3

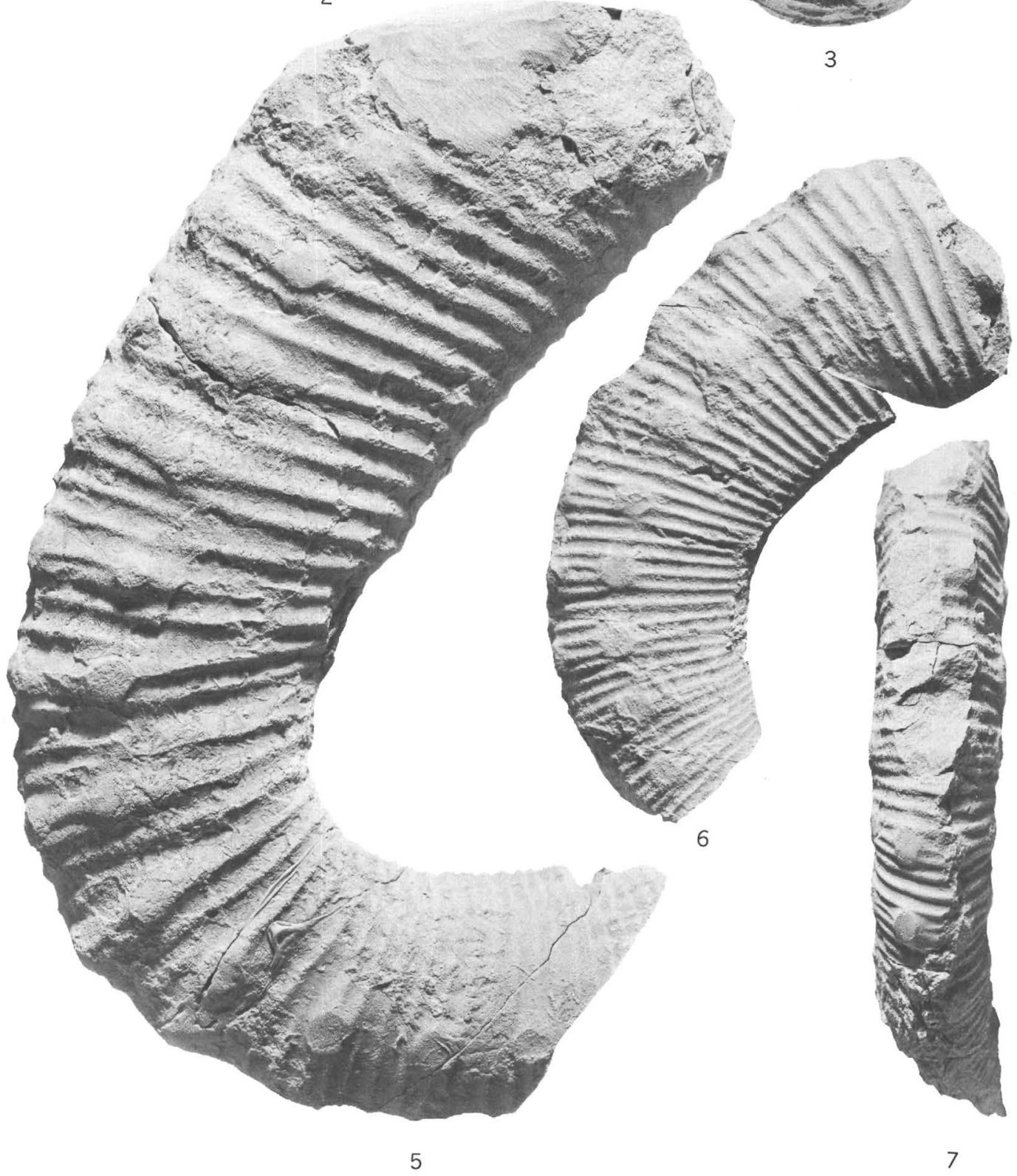

CALYCOCERAS NAVICULARE AND ANISOCERAS PLICATILE 


\section{PLATE 2}

[All figures natural size]

Figures 1-23. Desmoceras (Moremanoceras) scotti (Moreman) (p. 6).

1-4. Front, side, rear, and bottom views of a small specimen showing constrictions. From the Eagle Ford Formation at USGS loc. 19716, 2 miles northeast of Bells, Tex. Hypotype USNM 166340.

5, 6. Rear and side views of a slightly larger specimen from the same locality. Hypotype USNM 166341.

7,8 . Upper rear and side views of a larger specimen from the same locality showing a thickened rib on one side of a constriction. Hypotype USNM 166342.

9, 10. Side and rear views of a similar-sized specimen from the same locality showing several ribs. Hypotype USNM 166343 ,

11-14. Front, side, rear, and top views of a stout specimen from the same locality showing fine ribbing. Hypotype USNM 166344.

15-17. Front, side, and rear views of a specimen from the same locality showing two orders of ribbing. Hypotype USNM 166345.

18, 19. Side and rear views of a specimen from the base of the Mancos Shale at USGS loc. D7092 (text fig. 1, loc. 31). Hypotype USNM 166347.

20, 21. Rear and side views of the largest specimen from the same locality as figures 1-4. Hypotype USNM 166346.

22, 23. Front and side views of a large specimen from the base of the Bridge Creek Limestone Member of the Greenhorn Limestone at USGS loc. 22899 (text fig. 1, loc. 26). Hypotype USNM 166348.

24-26. Paracompsoceras landisi Cobban, n. sp. (p. 10).

Side, rear, and bottom views of the inner whorls of a paratype from USGS loc. D6130 (text fig. 1, loc. 34). USNM 166359. 
GEOLOGICAL SURVEY

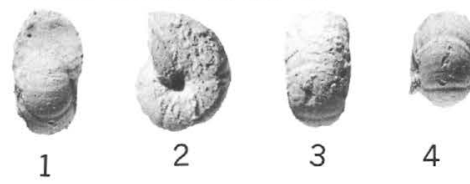

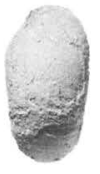

5

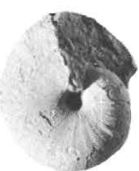

6
PROFESSIONAL PAPER 699

PLATE 2

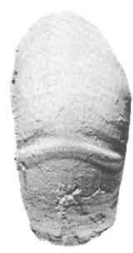

7

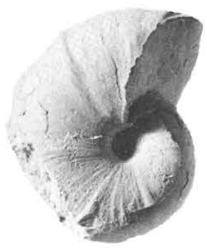

8

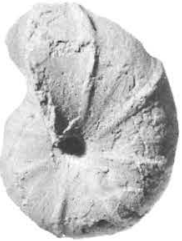

9
10

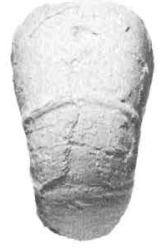

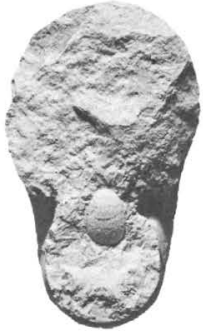

11

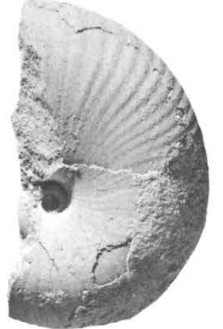

12

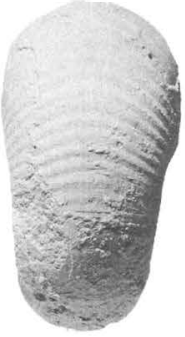

13

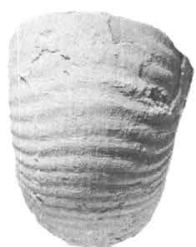

14

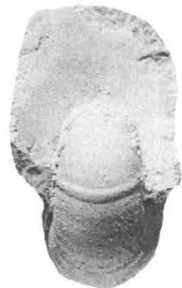

15

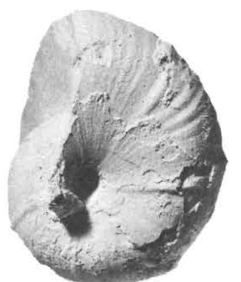

16

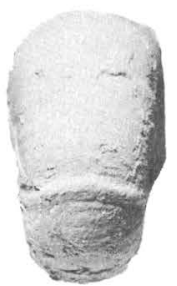

17

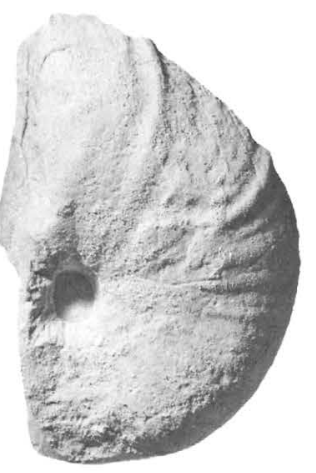

18

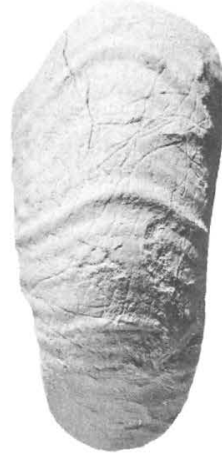

19

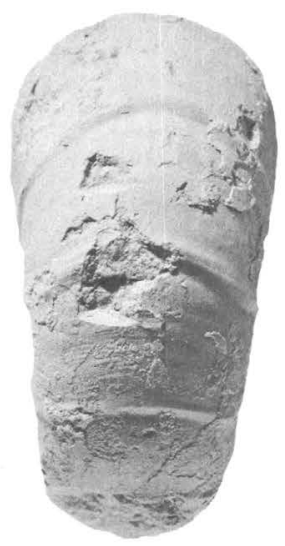

20

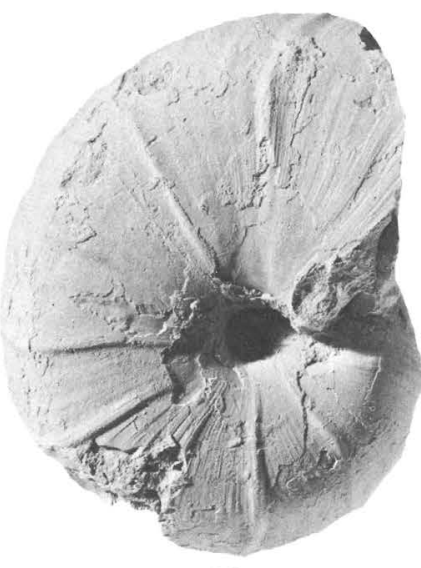

21
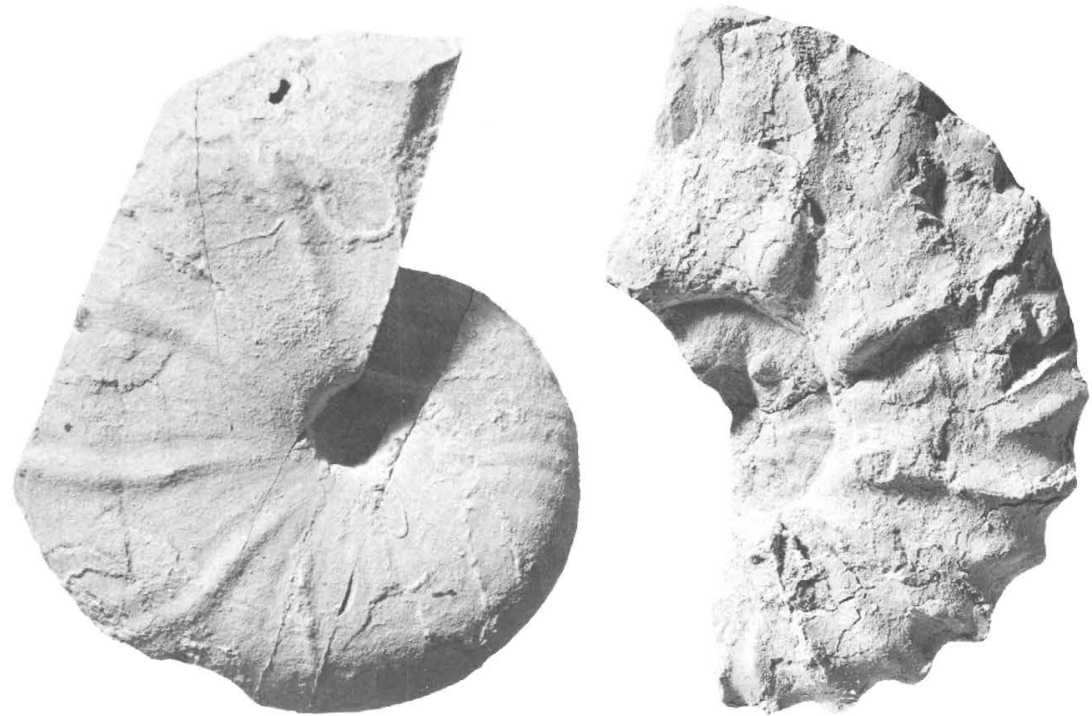

24

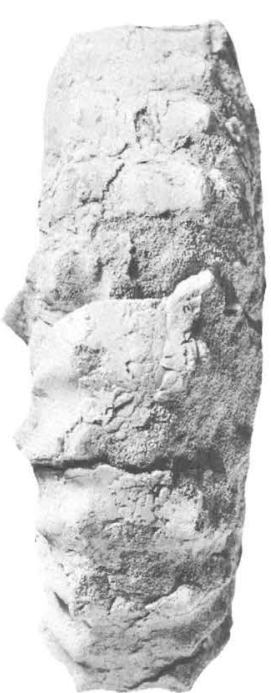

25

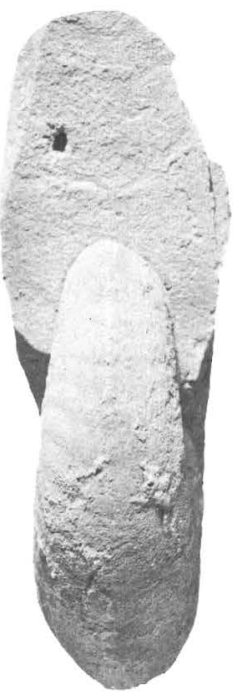

22

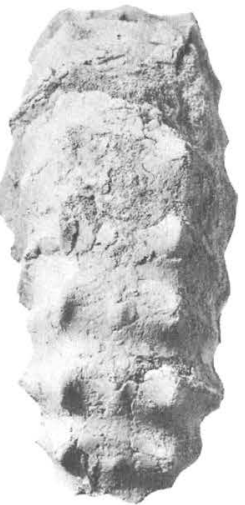

26

DESMOCERAS (MOREMANOCERAS) SCOTTI AND PARACOMPSOCERAS LANDISI 


\section{PLATE 3}

[Both figures natural size]

Figures 1, 2. Tragodesmoceras carlilense Cobban, n. sp. (p. 8).

Rear and side views of the holotype from the lower part of the Carlile Shale at USGS loc. 21792 (text fig. 1, loc. 4). See plate 5, figure 5 for front view. USNM 166349. 

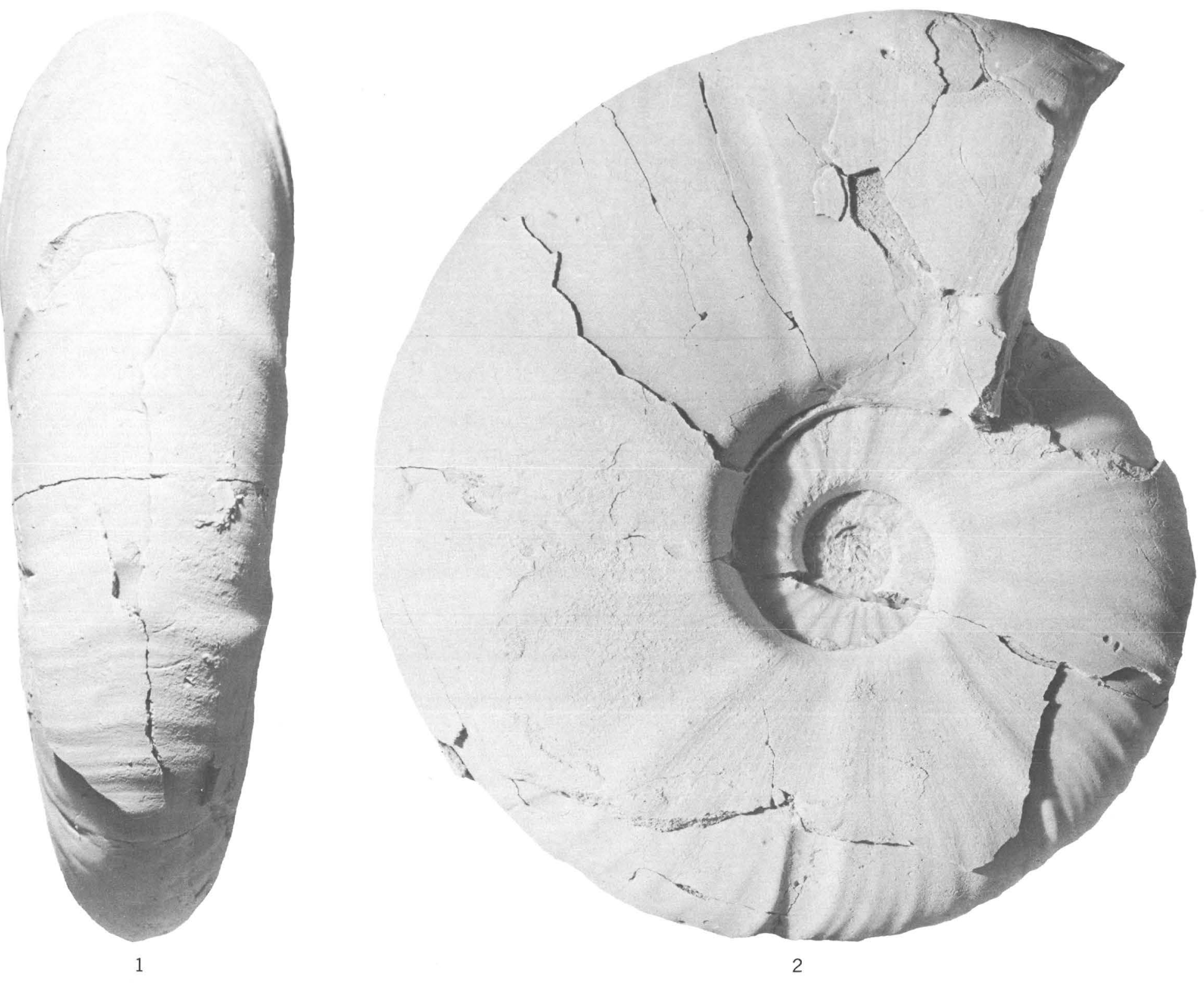

TRAGODESMOCERAS CARLILENSE 


\section{PLATE 4}

[All figures natural size]

Figures 1-16. Tragodesmoceras carlilense Cobban, n. sp. (p. 8).

From limestone concretions in the lower part of the Carlile Shale at localities along the flanks of the Black Hills. 1,2. Side and front views of a very small specimen from USGS loc. D3754 (text fig. 1, loc. 9). Paratype USNM 166350.

3-5. Front, side, and rear views of a juvenile from USGS loc. D411 (text fig. 1, loc. 2). Paratype USNM 166351. 6-8. Front, side, and rear views of a juvenile from USGS loc. D1450 (text fig. 1, loc. 12). Paratype USNM 166352. 9, 10. Rear and side views of a larger juvenile from USGS loc. 11190 (text fig. 1, loc. 5). Paratype USNM 166353 11-13. Front, side, and rear views of a specimen from USGS loc. 21792 (text fig. 1, loc. 4). Paratype USNM 166354.

14-16. Front, side, and rear views of the phragmocone of an adult from the same locality as figures 11-13. Paratype USNM 166355. 
GEOLOGICAL SURVEY

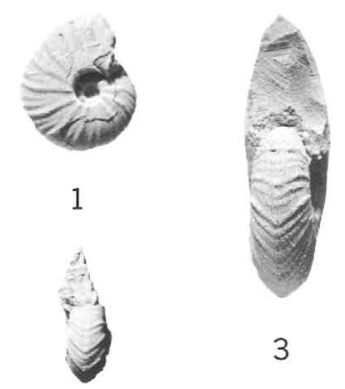

2

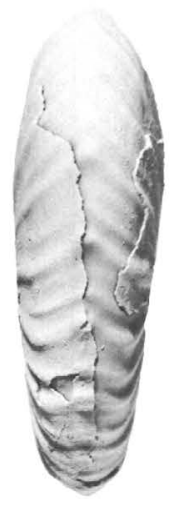

9

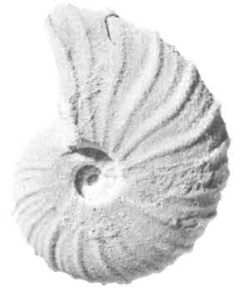

4

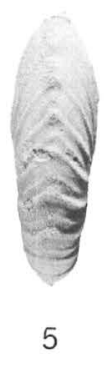

5

PROFESSIONAL PAPER 699 PLATE 4

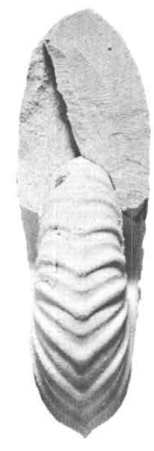

6

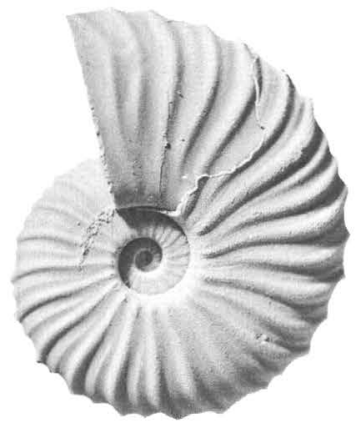

7

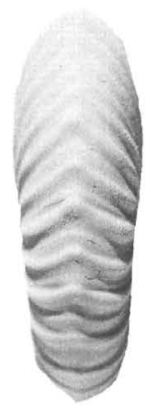

8

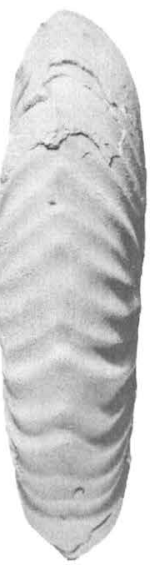

13

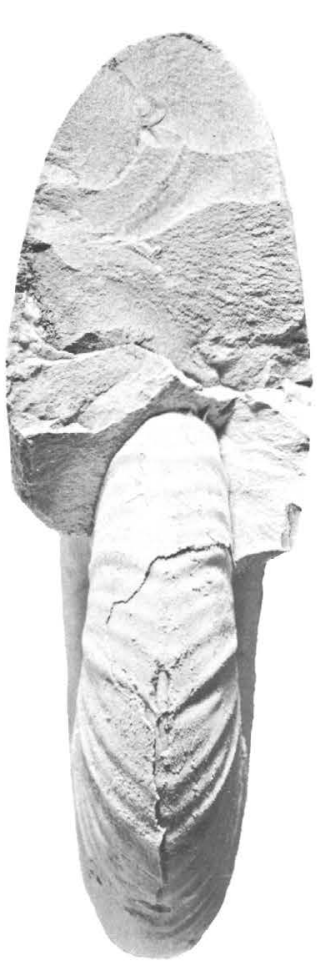

14

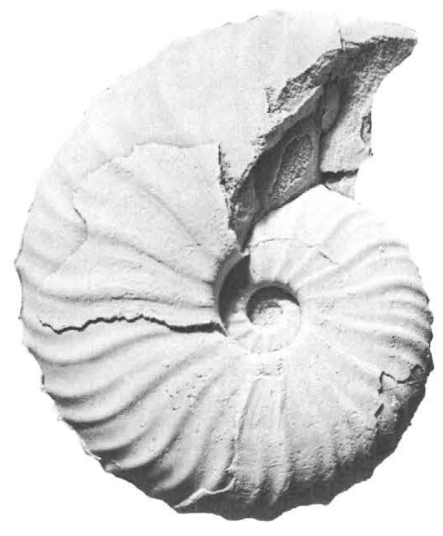

10

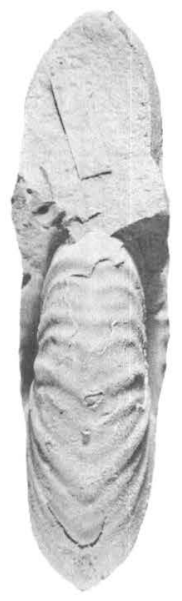

11

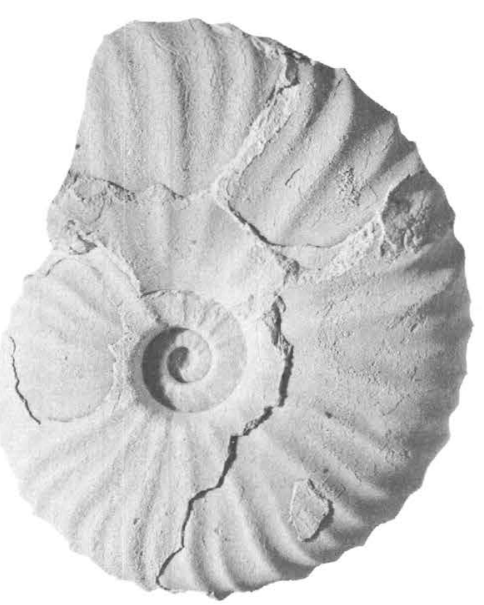

12

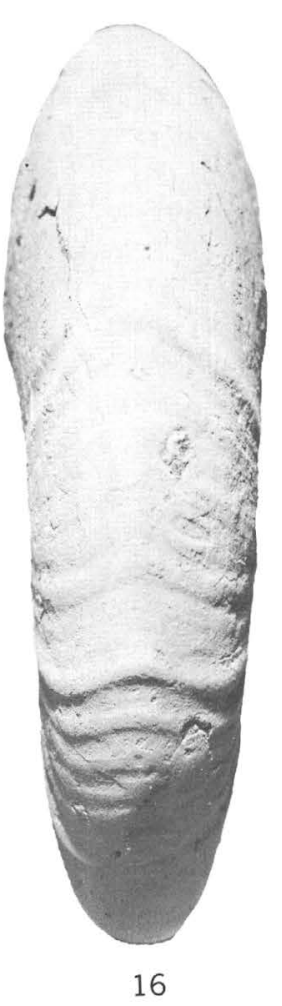

TRAGODESMOCERAS CARLILENSE 


\section{PLATE 5}

[All figures natural size]

Figures 1-5. Tragodesmoceras carlilense Cobban, n. sp. (p. 8).

From limestone concretions in the lower part of the Carlile Shale at localities along the flanks of the Black Hills.

1, 2. Side and front views of a slender specimen from USGS loc. 12642 (text fig. 1, loc. 14). Paratype USNM 166356.

3, 4. Front and side views of a septate specimen from USGS loc. 11192 (text fig. 1, loc. 7). The suture is shown in text figure 8. Paratype USNM 166357.

5. Front view of the holotype from USGS loc. 21792 (text fig. 1, loc. 4). An impression of Collignoniceras woollgari (Mantell) is visible in the matrix that fills the body chamber. Rear and side views are shown in plate 3. USNM 166349. 
GEOLOGICAL SURVEY

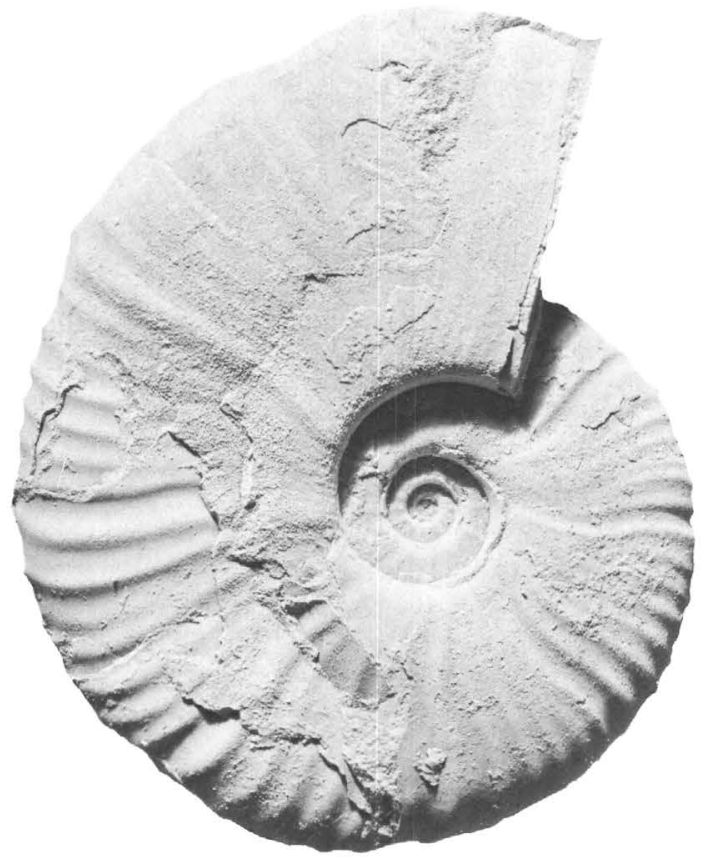

1

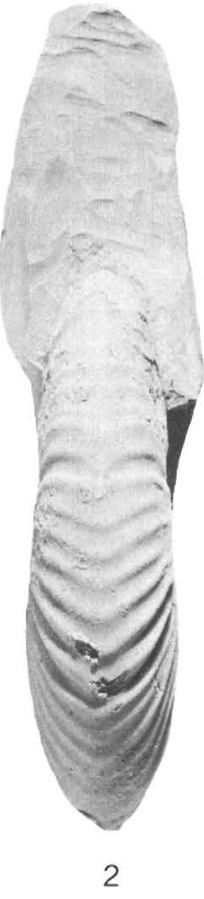

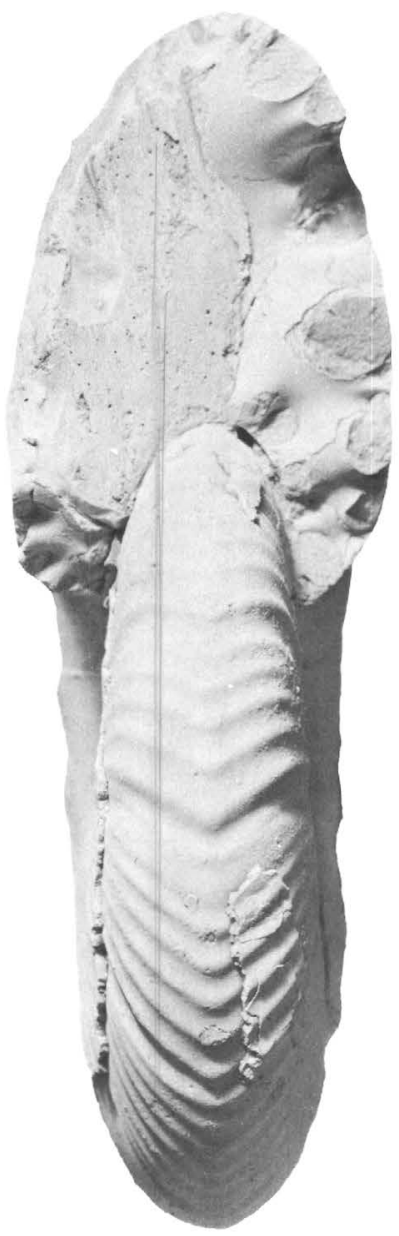

3

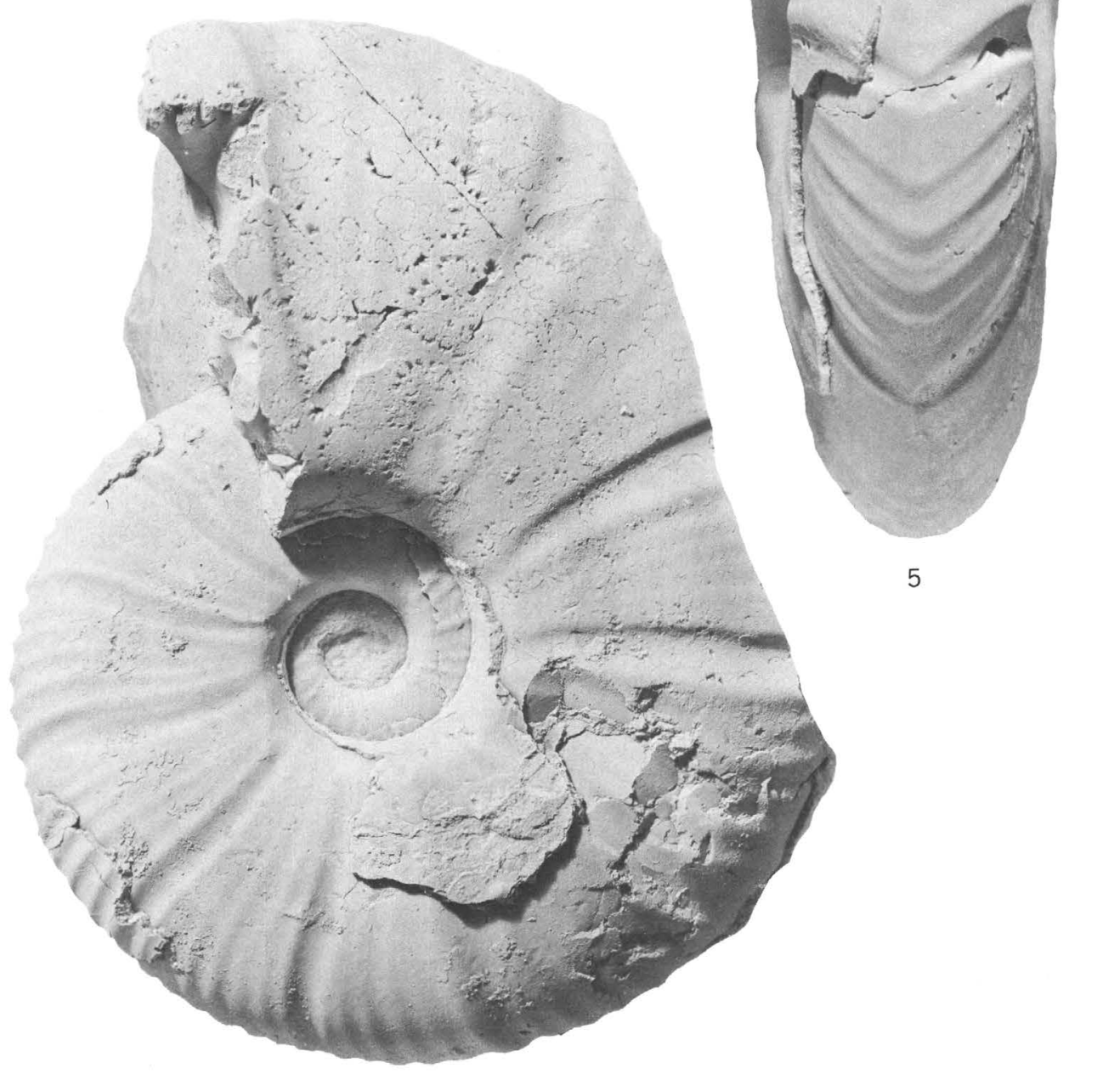

4

TRAGODESMOCERAS CARLILENSE 


\section{PLATE 6}

[Figure seven-eighths natural size]

Paracompsoceras landisi Cobban, n. gen. and n. sp. (p. 10).

Side view of the holotype from USGS loc. D6130 (text fig. 1, loc. 34). USNM 166358. 




PARACOMPSOCERAS LANDISI 


\section{PLATE 7}

[Figure eight-tenths natural size]

Paracompsoceras landisi Cobban, n. gen. and n. sp. (p. 10).

Side view of a large stout paratype from USGS loc. D7084 (text fig. 1, loc. 35). See text figure $11 B$ for whorl section. USNM 166360 . 


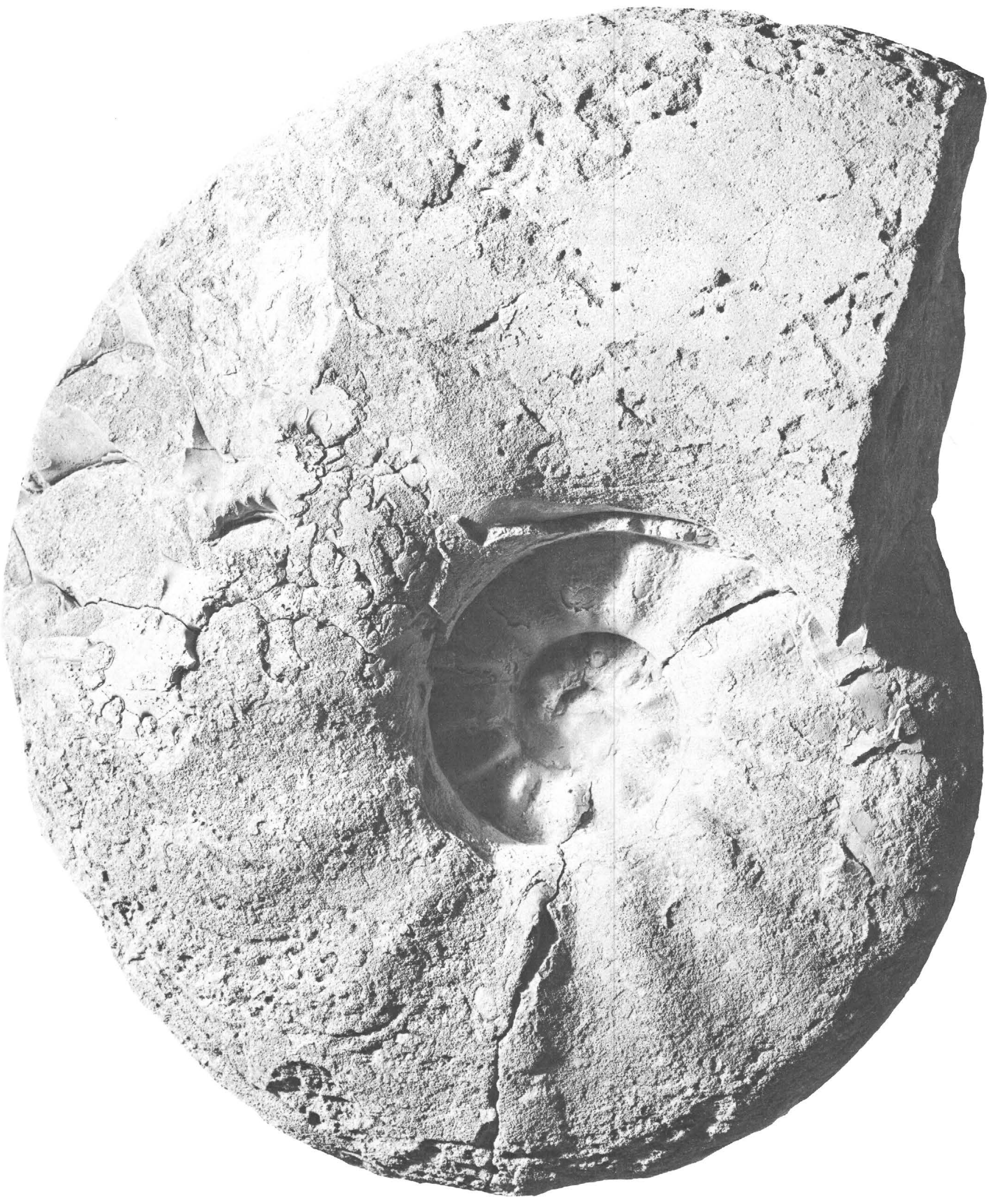

PARACOMPSOCERAS LANDISI 


\section{PLATE 8}

[Figure eight-tenths natural size]

Paracompsoceras landisi Cobban, n. gen. and n. sp. (p. 10).

Side view of a slender paratype from USGS loc. D7084 (text fig. 1, loc. 35). See text figure $11 A$ for whorl section. USNM 166361. 


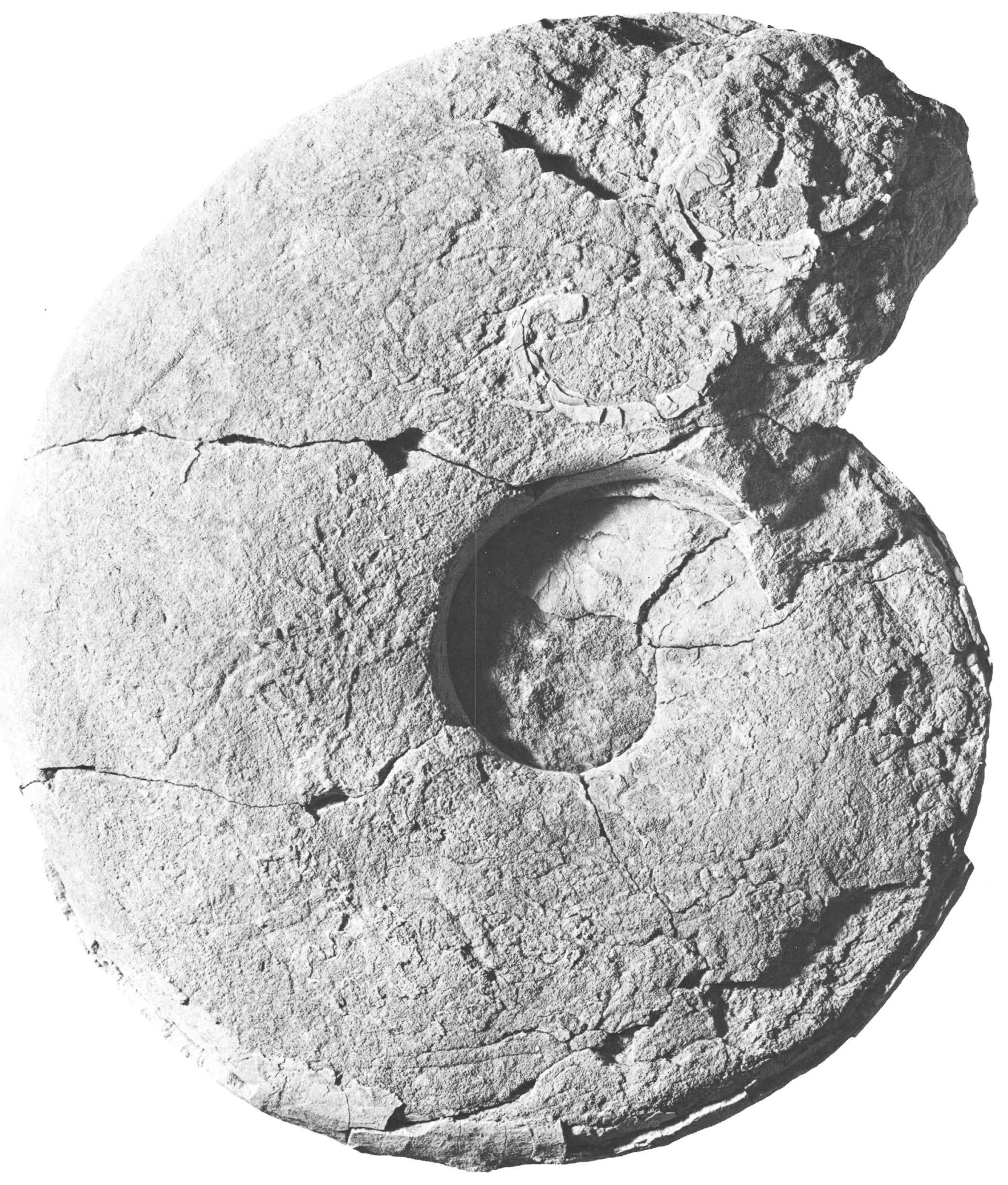

PARACOMPSOCERAS LANDISI 


\section{PLATE 9}

[All figures natural size]

Figures 1-4. Nigericeras scotti Cobban, n. sp. 18).

Rear, side, front, and top views of the holotype from near the base of the Bridge Creek Limestone Member of the Greenhorn Limestone at USGS loc. D6756 (text fig. 1, loc. 29). USNM 166396.

5-8. Paracompsoceras landisi Cobban, n. gen. and n. sp. (p. 10).

Rear and side views of the inner whorls of the holotype from USGS loc. D6130 (text fig. 1, loc. 34). See plate 6 for the adult shell. USNM 166358. 
GEOLOGICAL SURVEY

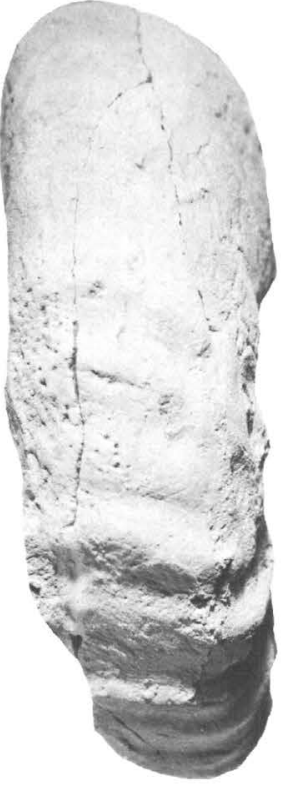

1

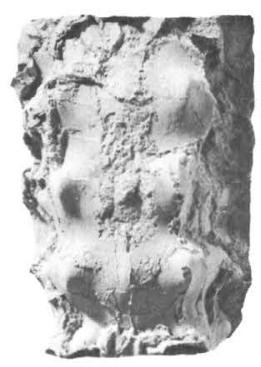

5

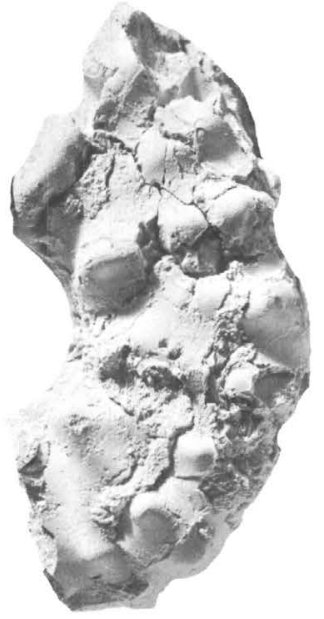

6

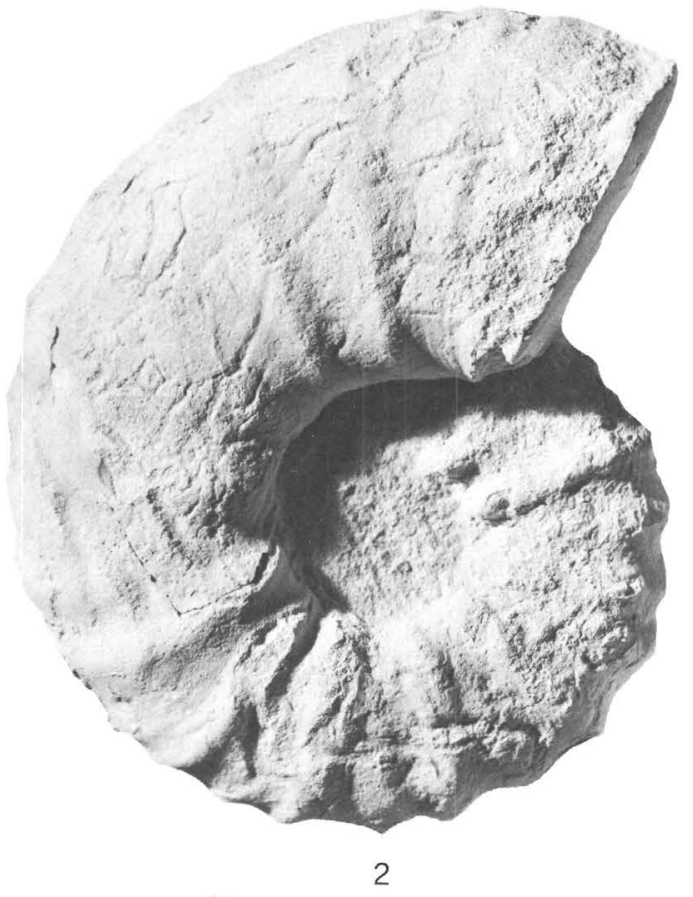

PROFESSIONAL PAPER 699 PLATE 9
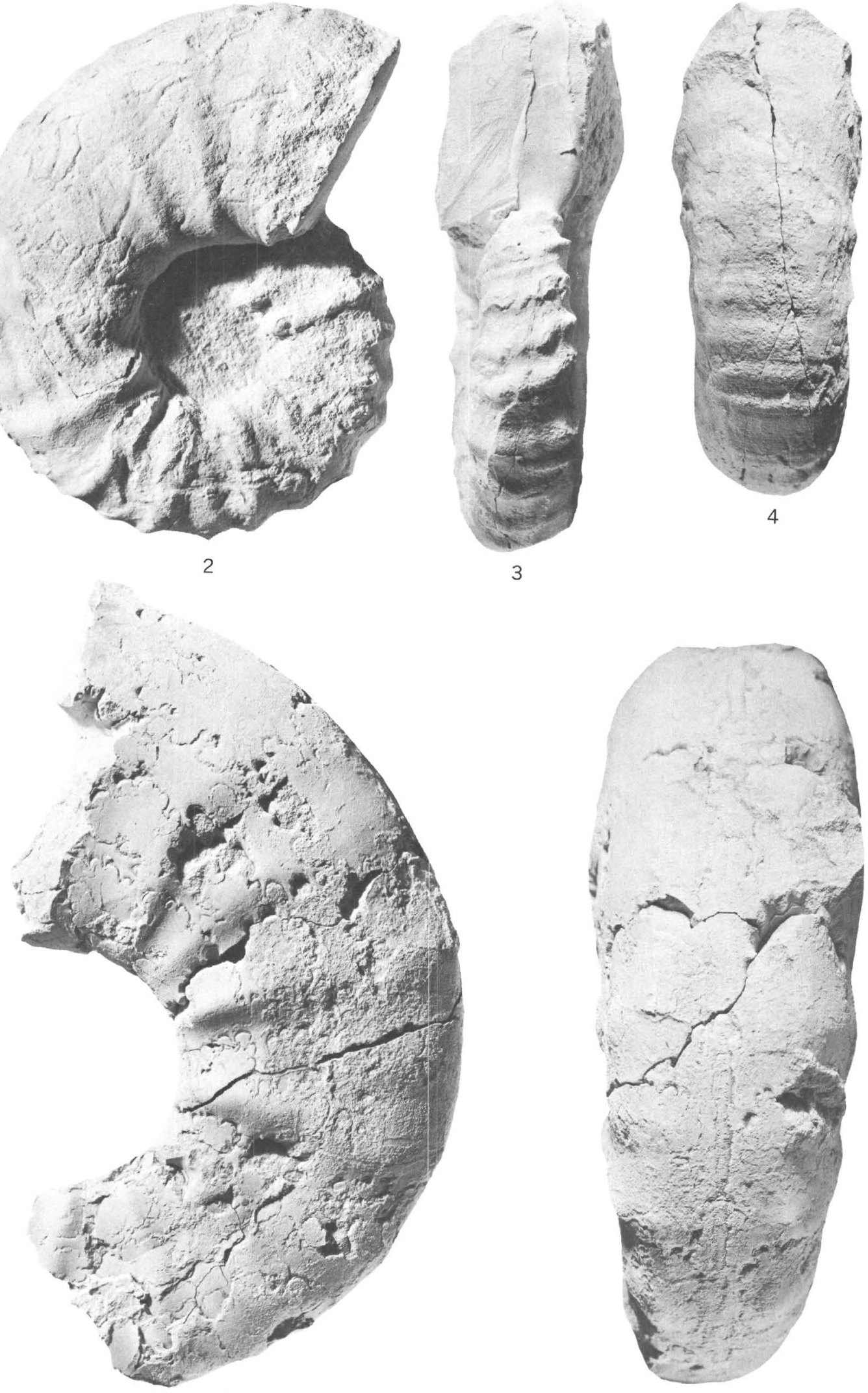

7

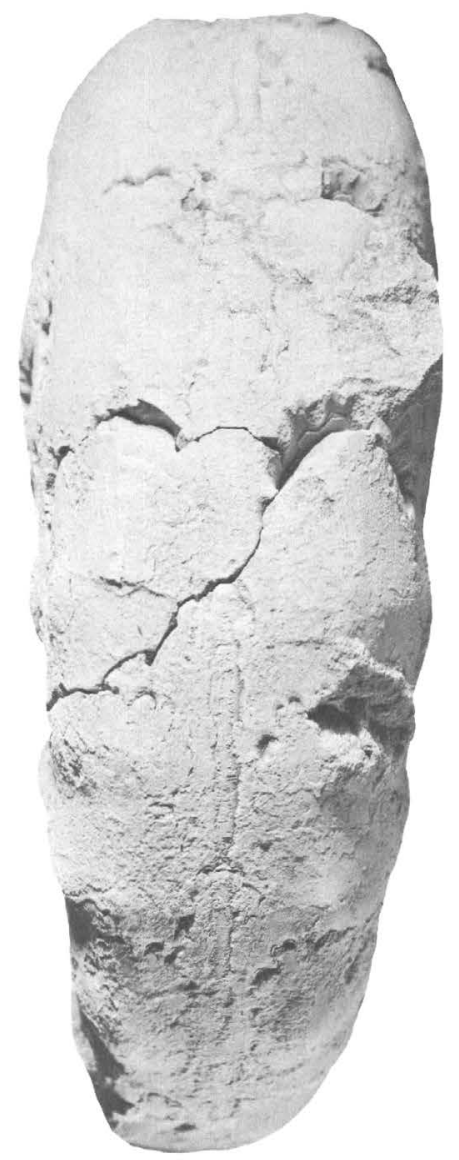

8

NIGERICERAS SCOTTI AND PARACOMPSOCERAS LANDISI 


\section{PLATE 10}

[All figures natural size]

Figures 1-8. Calycoceras naviculare (Mantell) (p. 13).

From the basal bed of the Bridge Creek Limestone Member of the Greenhorn Limestone on the Model anticline in southeast Colorado.

1, 2. Front and side views of the smallest specimen studied, a distorted internal mold from USGS loc. 18683 (text fig. 1, loc. 21). Hypotype USNM 166392.

3, 5. Rear and side views of a fragment of a stout specimen that has depressed whorls from USGS loc. 22899 (text fig. 1, loc. 26). See text figure $13 G$ for whorl section. Hypotype USNM 166380.

4, 7. Rear and side views of a specimen from USGS loc. 18686 (text fig. 1, loc. 24) that developed a ventrolateral angularity on the ribs at an unusually small diameter. Hypotype USNM 166368.

6. Side view of a specimen from USGS loc. 22899 (text fig. 1, loc. 26). The lateral lobe is shown in text figure 14 and the whorl section in text figure $13 F$. Hypotype USNM 166372.

8. Side view of a moderate-sized specimen from the same locality as that of figure 6 . See plate 11 , figures 4 and 5 for other views and text figure $13 D$ for the whorl section. Hypotype USNM 166373. 


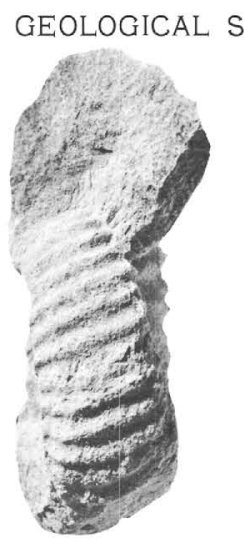

1

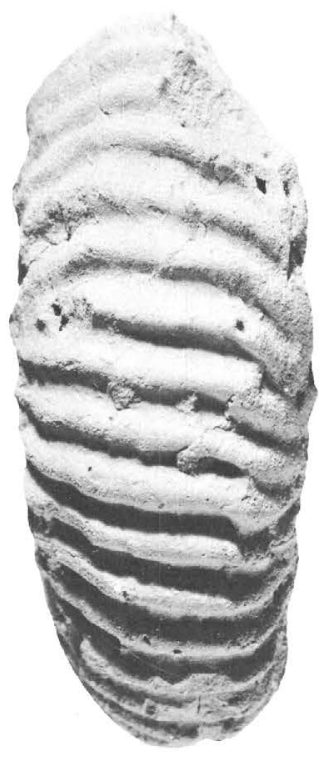

4

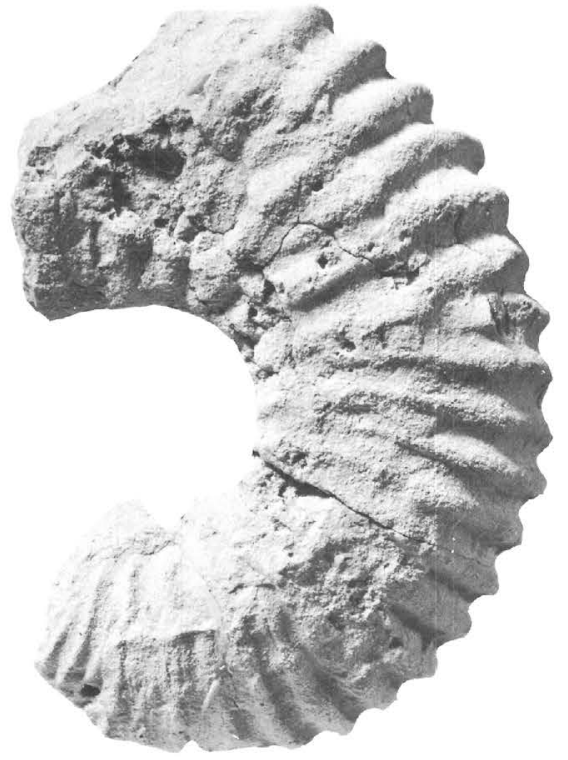

7
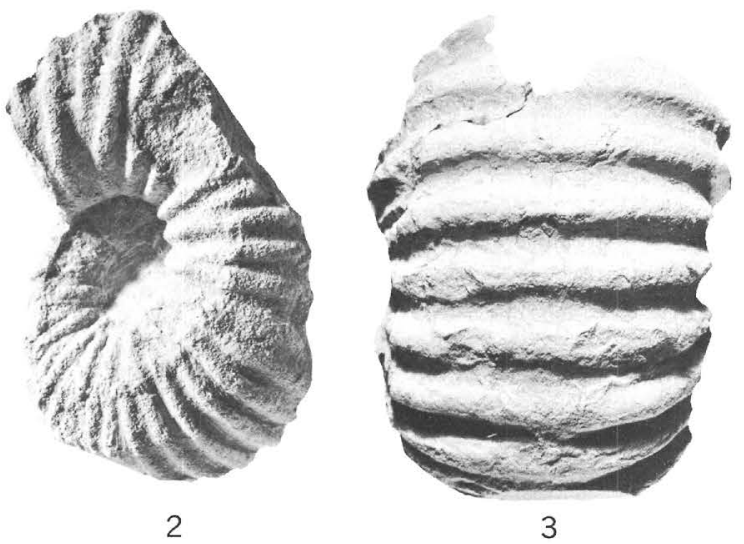

PROFESSIONAL PAPER 699 PLATE 10


5
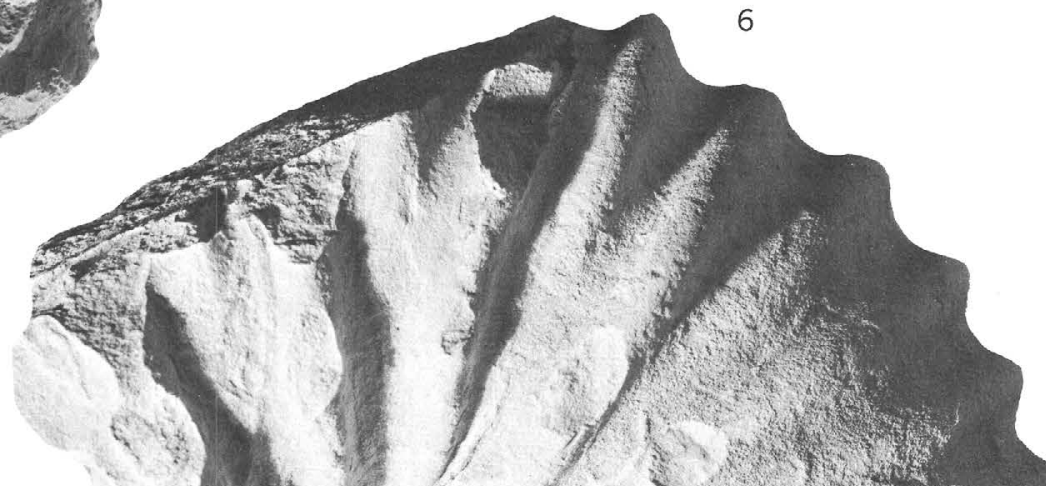

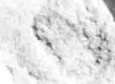

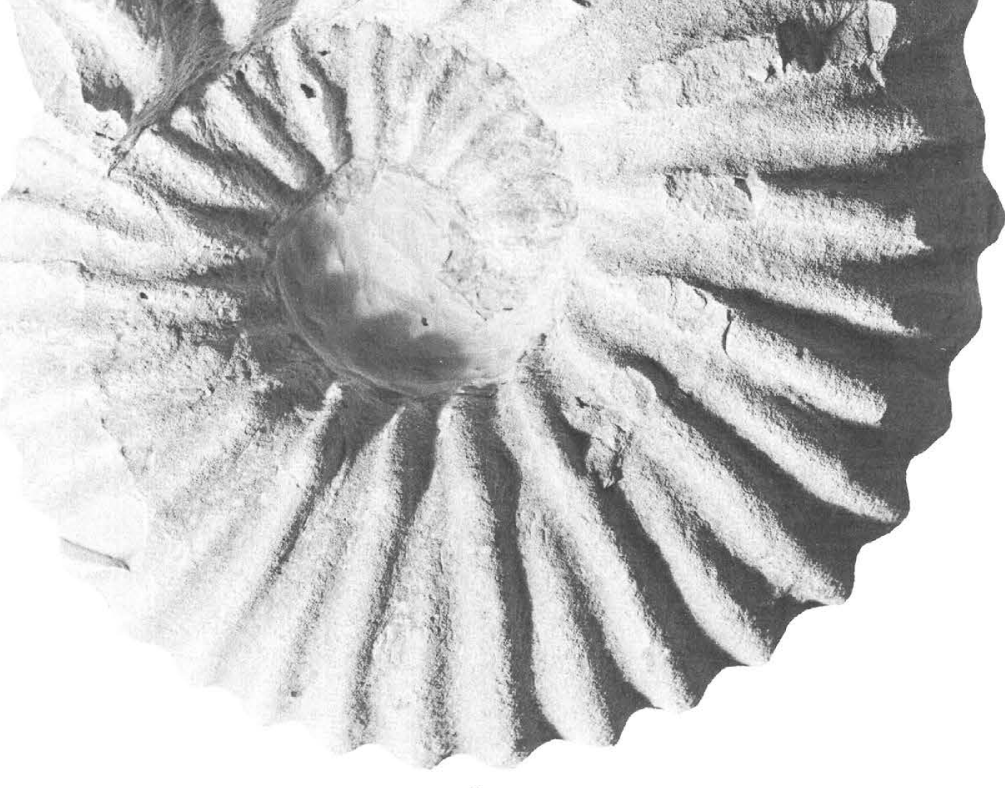

CALYCOCERAS NAVICULARE 


\section{PLA'TE 11}

[All figures natural size]

Figures 1-5. Calycoceras naviculare (Mantell) (p. 13).

From the basal bed of the Bridge Creek Limestone Member of the Greenhorn Limestone on the Model anticline in southeast Colorado.

1-3. Rear, side, and front views of a small specimen from USGS loc. 18686 (text fig. 1, loc. 24). Hypotype USNM 166363.

4, 5. Front and rear views of a larger specimen from USGS loc. 22899 (text fig. 1, loc. 26) showing a faint ventrolateral angularity. See plate 10 , figure 8 for the side view and text figure $13 D$ for the whorl section. Hypotype USNM 166373. 


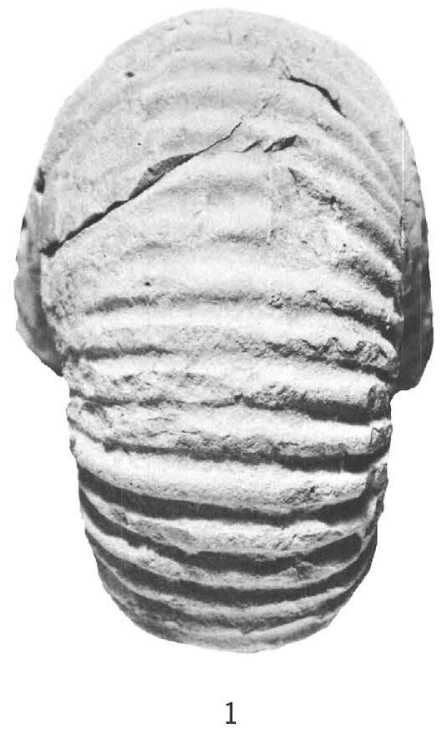

1

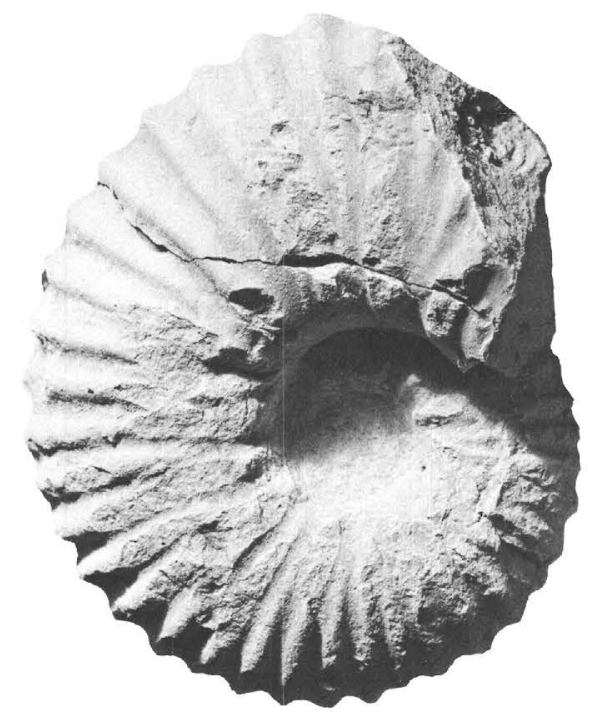

2

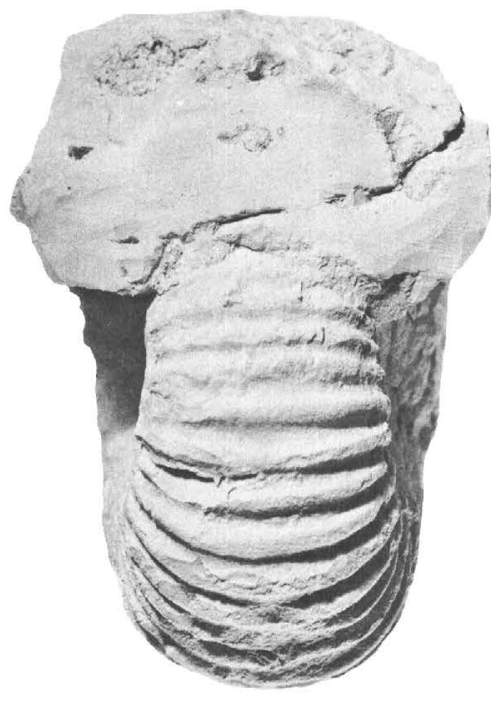

3

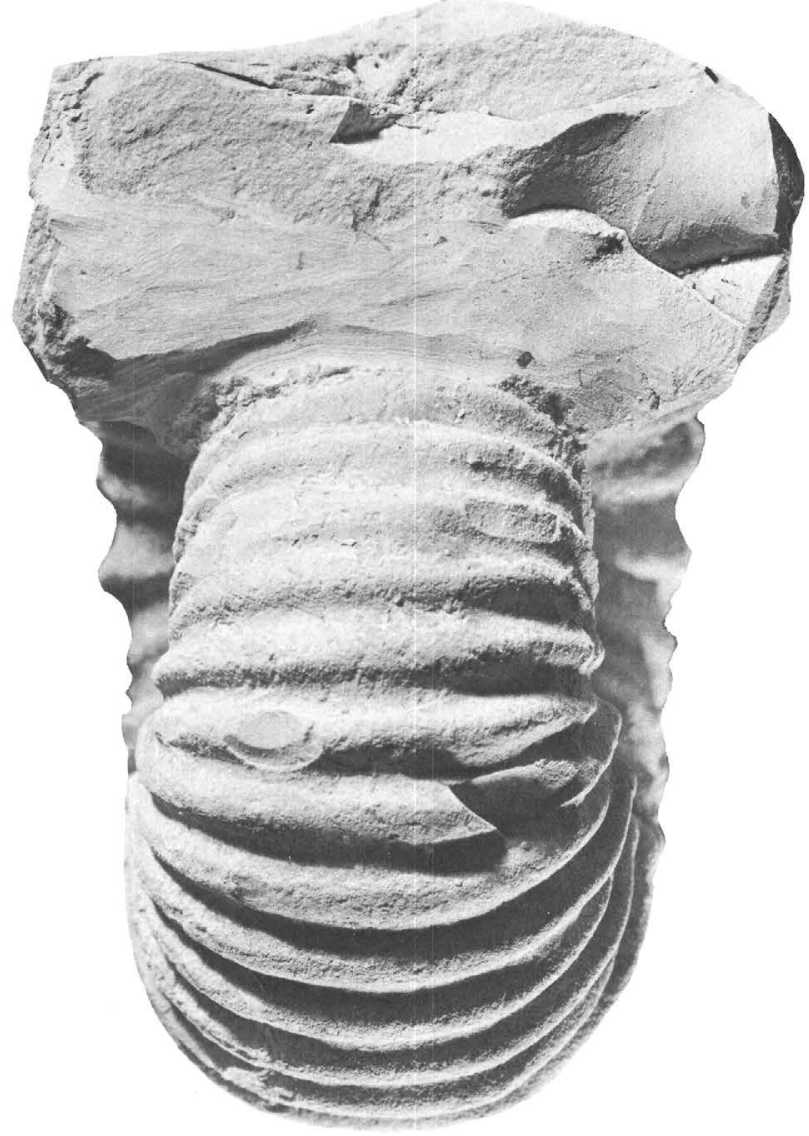

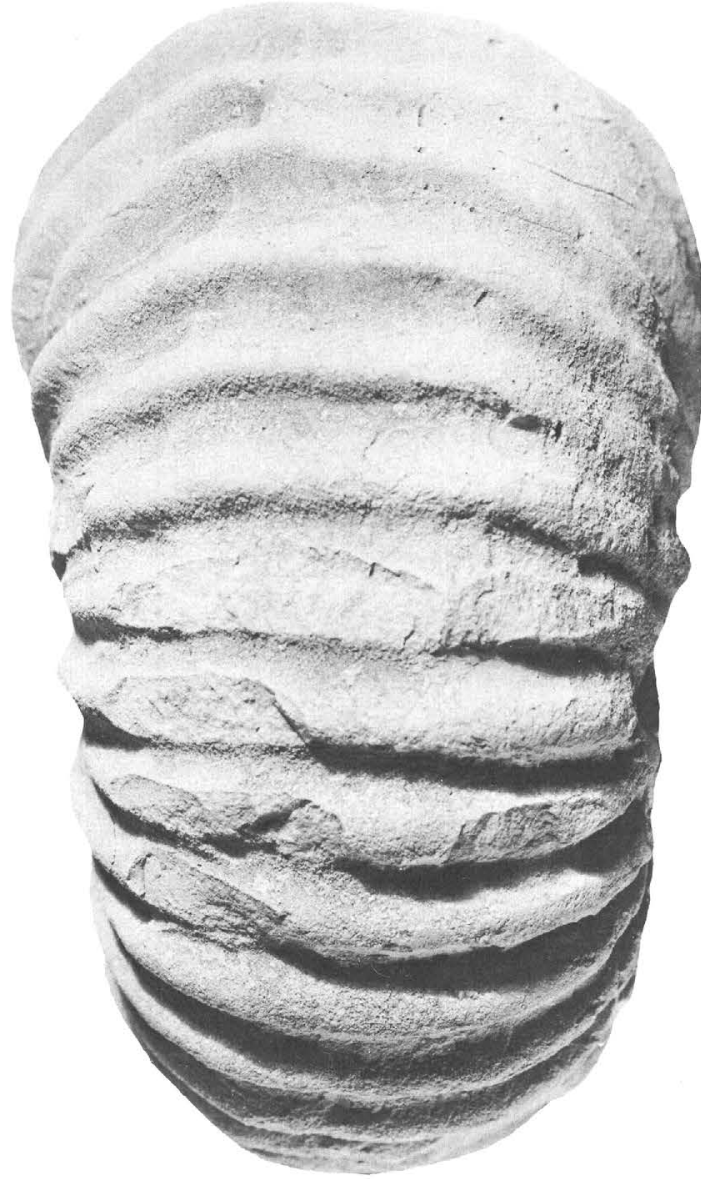

5

CALYCOCERAS NAVICULARE 


\section{PLATE 12}

[Both figures natural size]

Figures 1, 2. Calycoceras naviculare (Mantell) (p. 13).

Side and front views of a specimen from the basal bed of the Bridge Creek Limestone Member of the Greenhorn Limestone at USGS loc. 18686 (text fig. 1, loc. 24). Hypotype USNM 166364. 


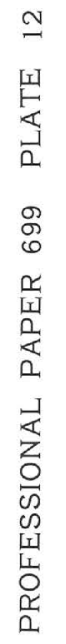
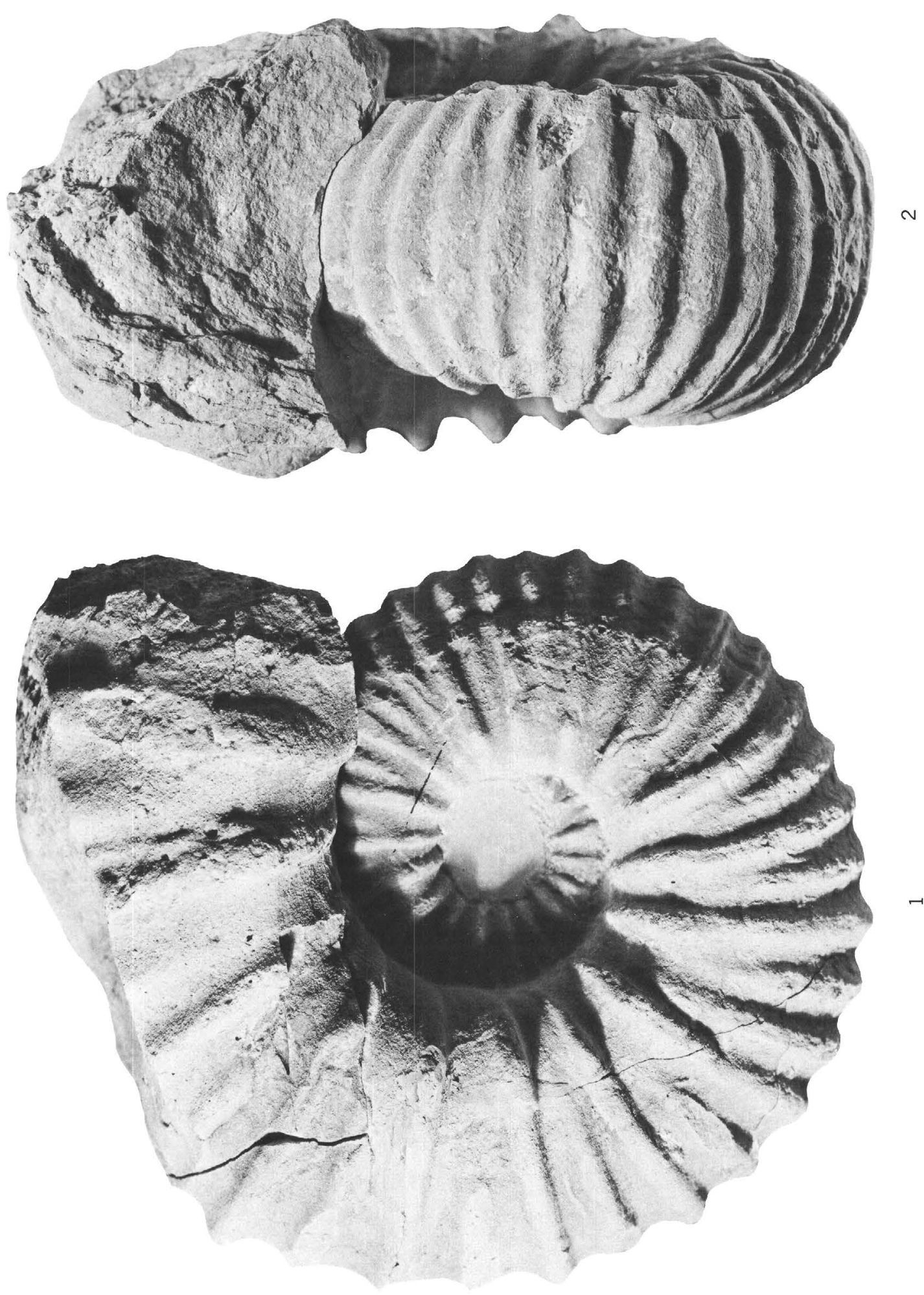



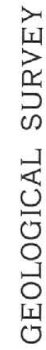




\section{PLATE 13}

[All figures natural size]

Figures 1-5. Calycoceras naviculare (Mantell) (p. 13).

From the basal bed of the Bridge Creek Limestone Member of the Greenhorn Limestone at localities on the Model anticline in southeast Colorado.

1-3. Front, side, and rear views of an unusually slender specimen from USGS loc. 22899 (text fig. 1, loc. 26). See text figure $13 C$ for the whorl section. Hypotype USNM 166378.

4, 5. Side and rear views of a very stout specimen from USGS loc. 18686 (text fig. 1, loc. 24). See plate 1, figures 1-3 for views of the inner whorls. Hypotype USNM 166362. 


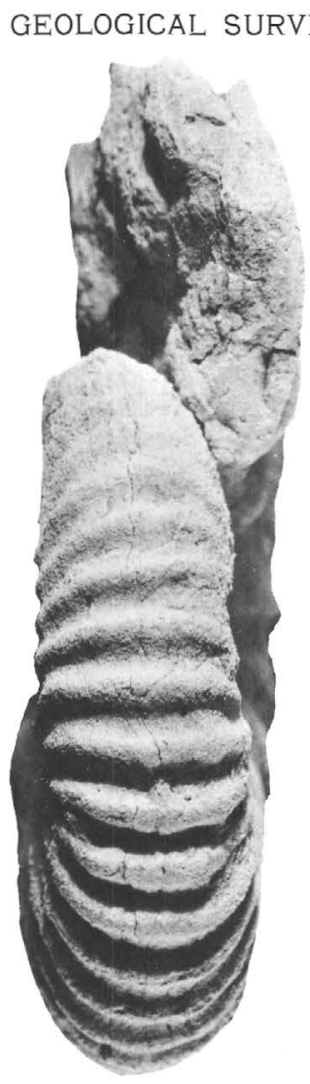

1
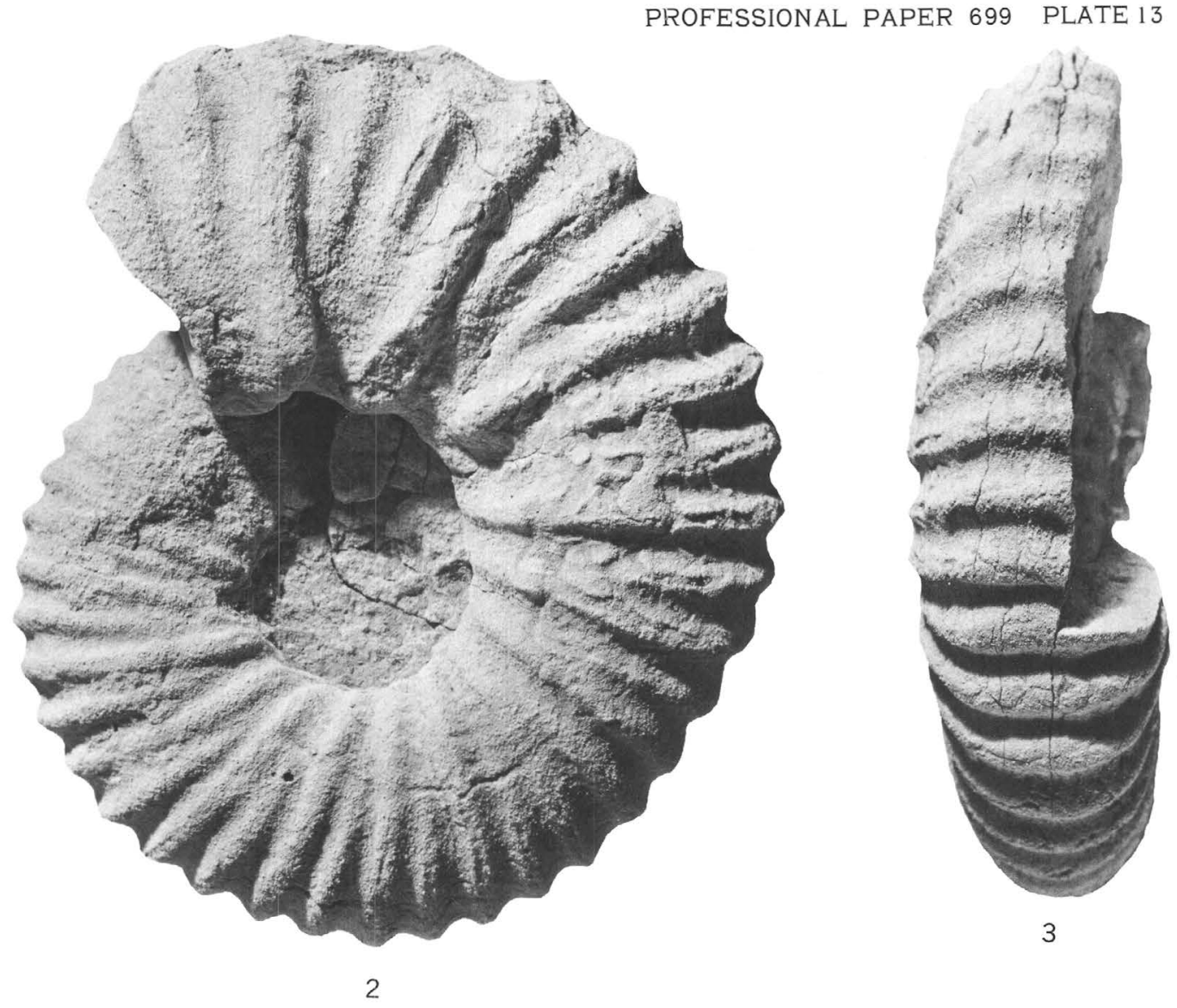

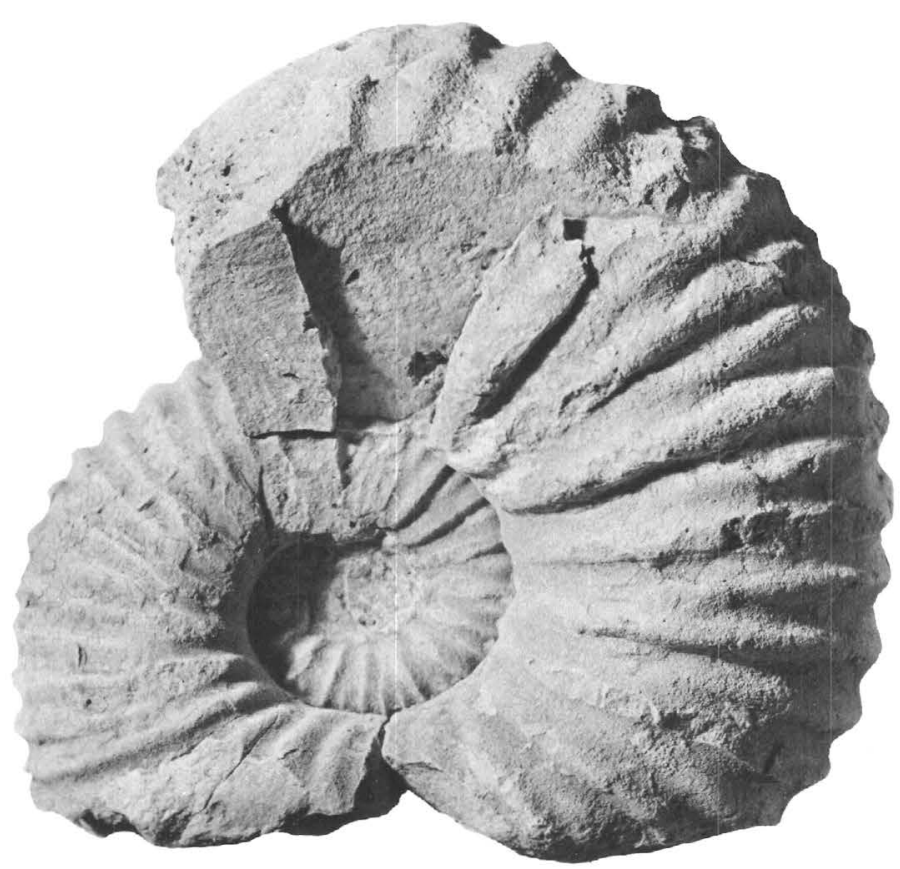

4

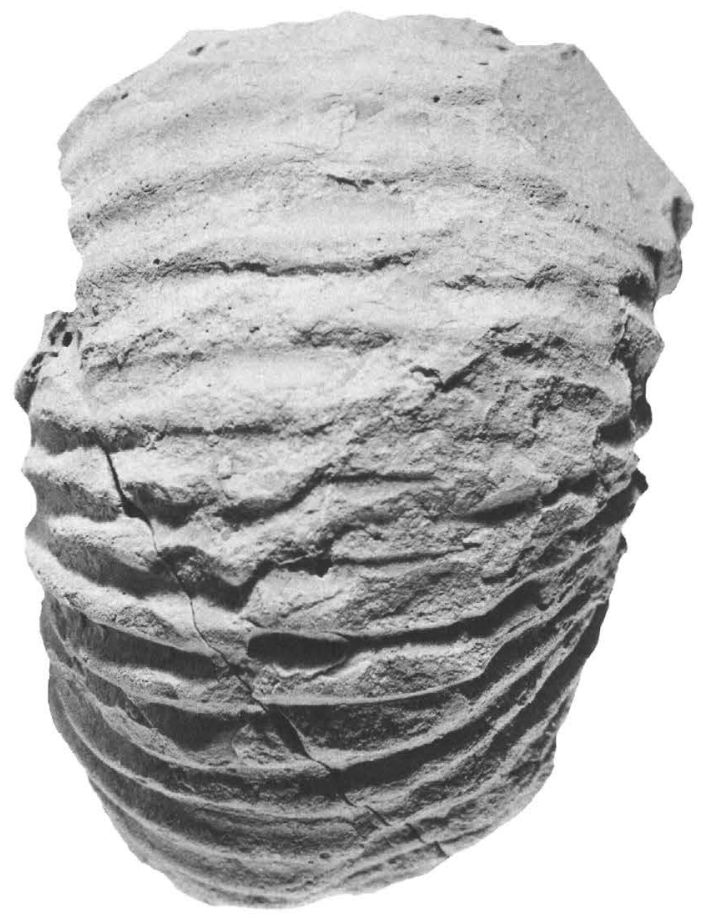

5

CALYCOCERAS NAVICULARE 


\section{PLATE 14}

[All figures natural size]

Figures 1-3. Calycoceras naviculare (Mantell) (p. 13).

Front, side, and rear views of a moderately slender specimen from the basal bed of the Bridge Creek Limestone Member of the Greenhorn Limestone at USGS loc. 22899 (text fig. 1, loc. 26). Hypotype USNM 166375. 


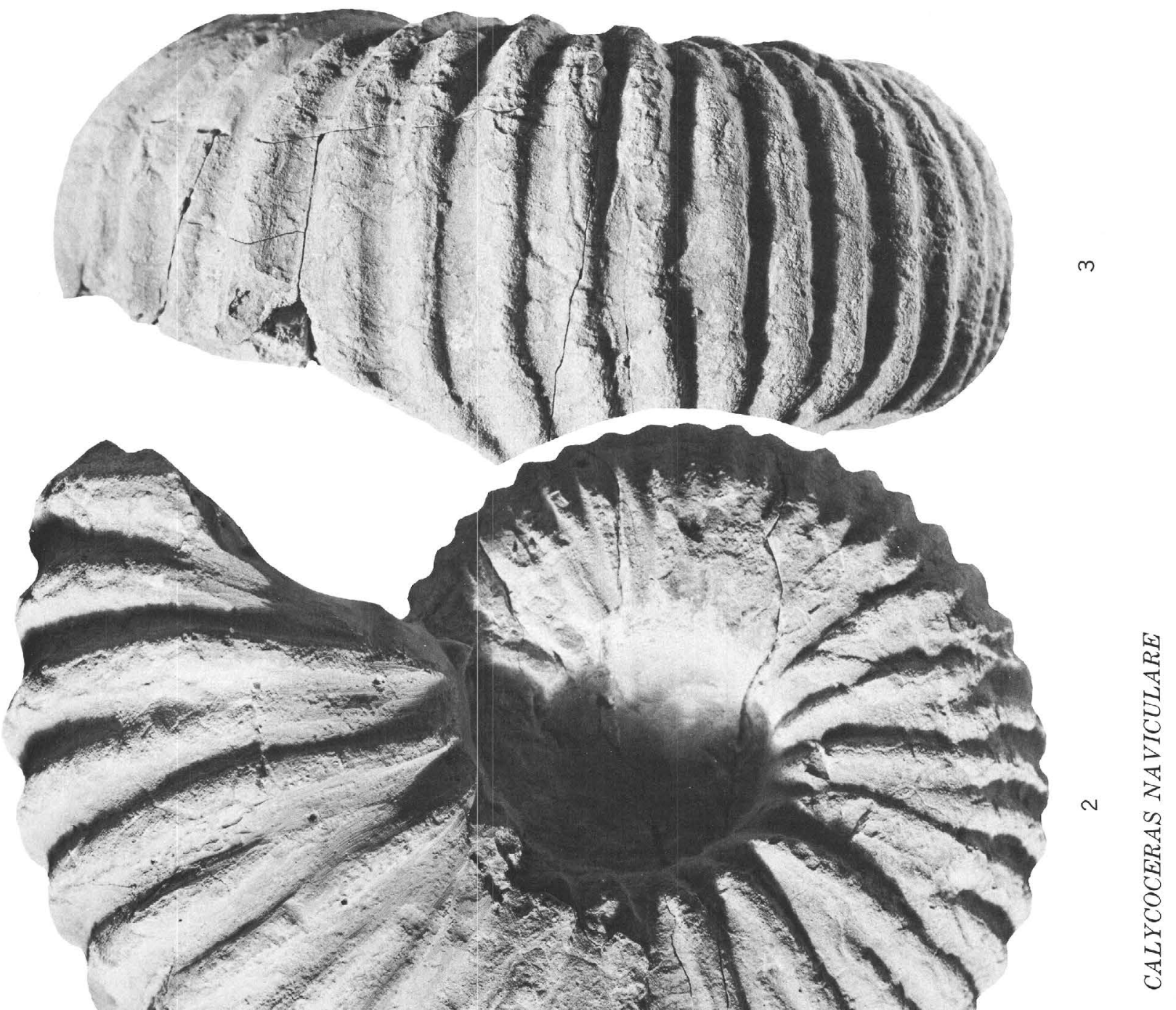




PLATE 15

[Both figures natural size]

Figures 1, 2. Calycoceras naviculare (Mantell) (p. 13).

Side and rear views of a sparsely ribbed slender specimen from the basal bed of the Bridge Creek Limestone Member of the Greenhorn Limestone at USGS loc. 18686 (text fig. 1, loc. 24). See text figure $13 A$ for the whorl section. Hypotype USNM 166367. 

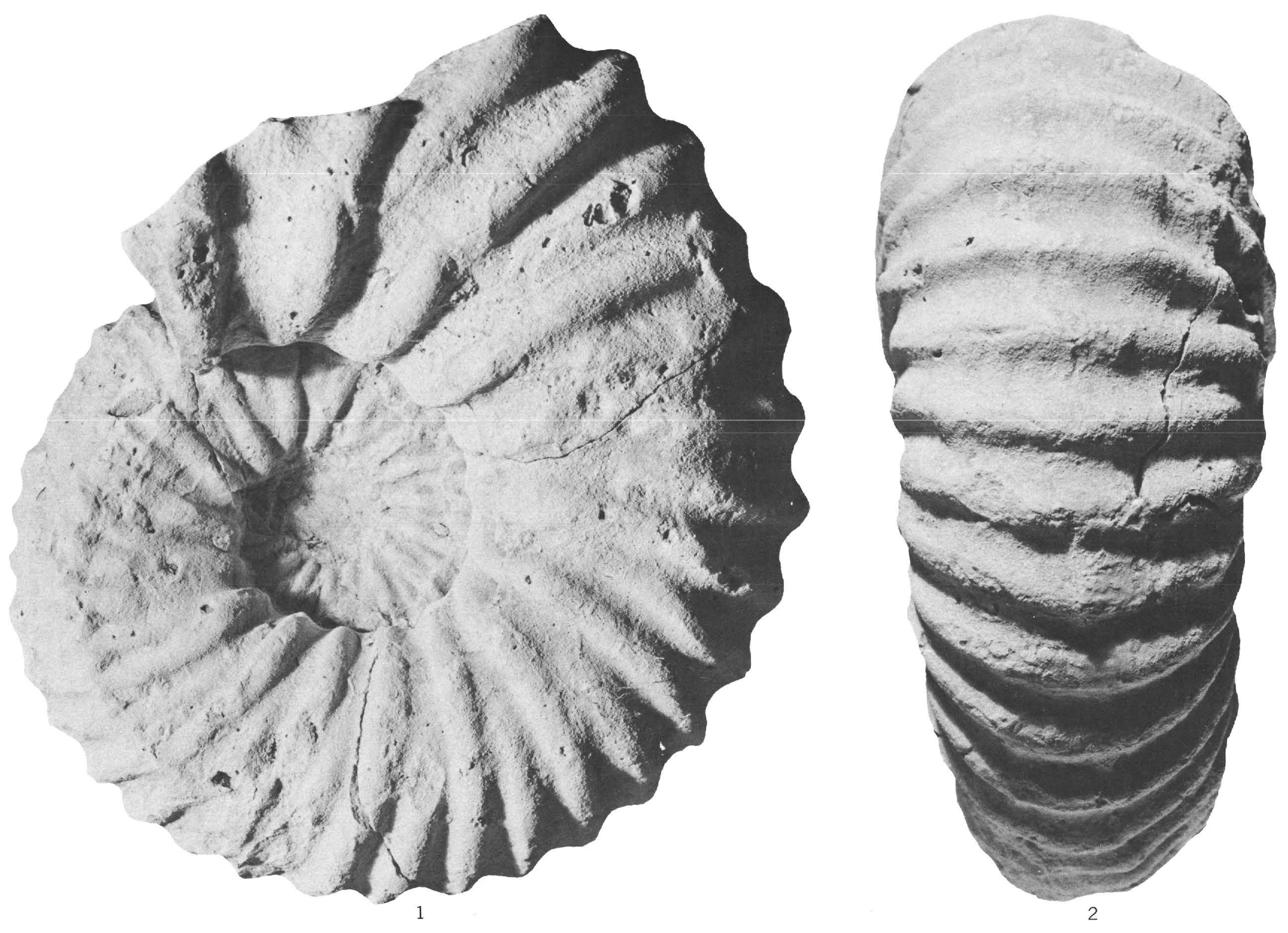

CALYCOCERAS NAVICULARE 


\section{PLATE 16}

[Both figures natural size]

Figures 1, 2. Calycoceras naviculare (Mantell) (p. 13).

Rear and side views of a specimen from the basal bed of the Bridge Creek Limestone Member of the Greenhorn Limestone at USGS loc. 18686 (text fig. 1, loc. 24) showing a slight ventrolateral angularity. Hypotype USNM 166365 . 
GEOLOGICAL SURVEY

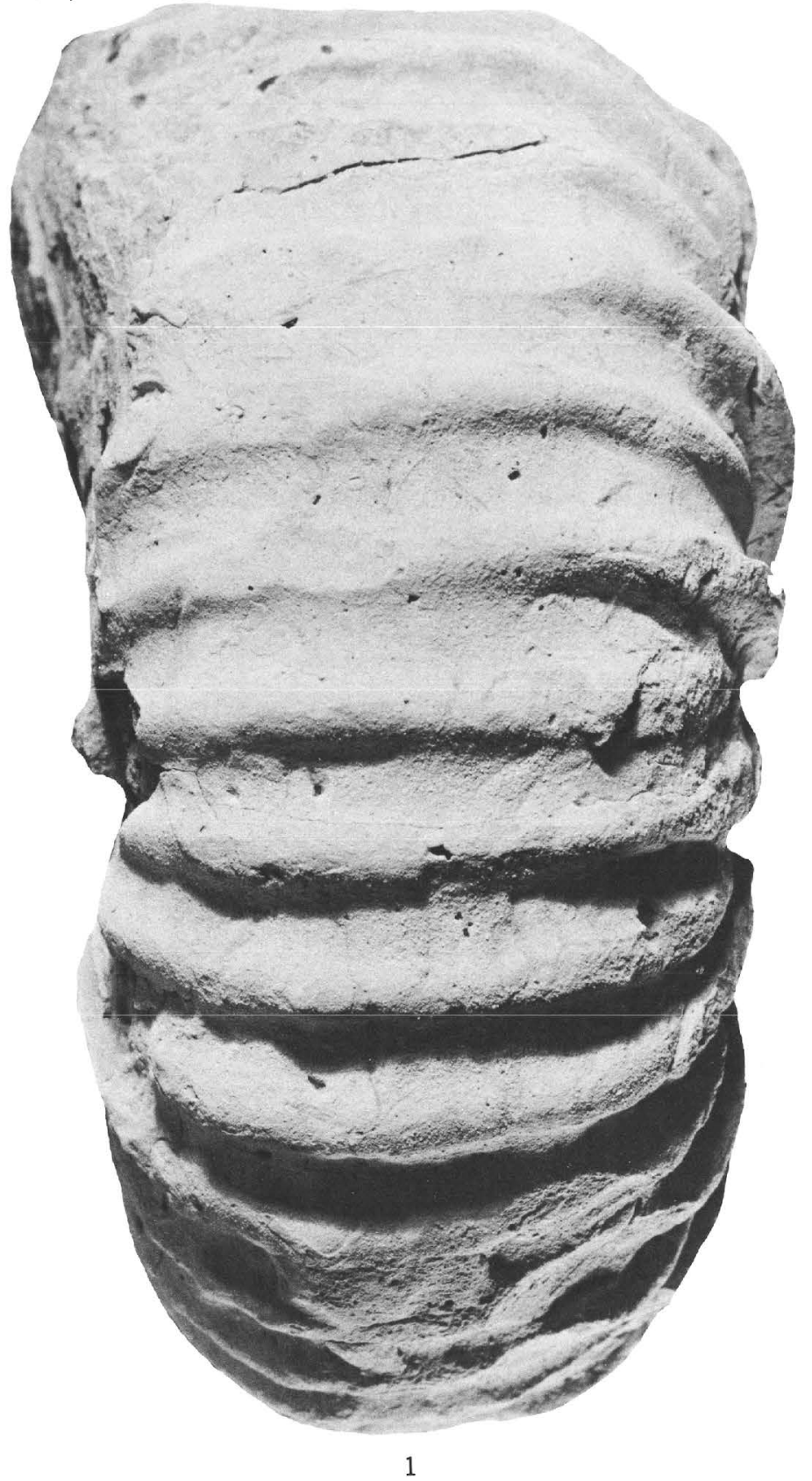

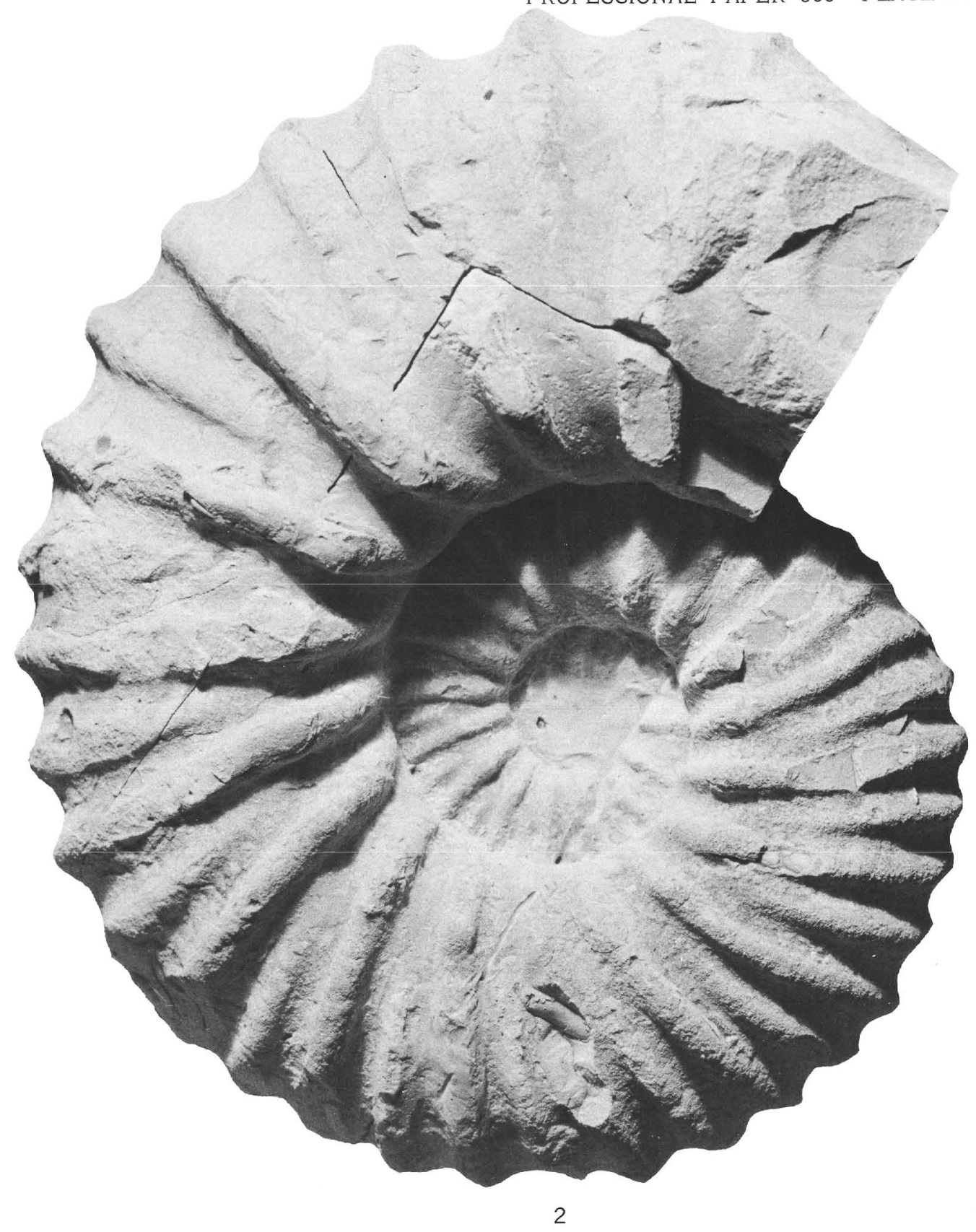

CALYCOCERAS NAVICULARE 
PLATE 17

[Figure natural size]

Calycoceras naviculare (Mantell) (p. 13).

Side view of a large specimen from the basal bed of the Bridge Creek Limestone Member of the Greenhorn Limestone at USGS loc. 18686 (text fig. 1, loc. 24). See text figure $13 H$ for the whorl section. Hypotype USNM 166366. 


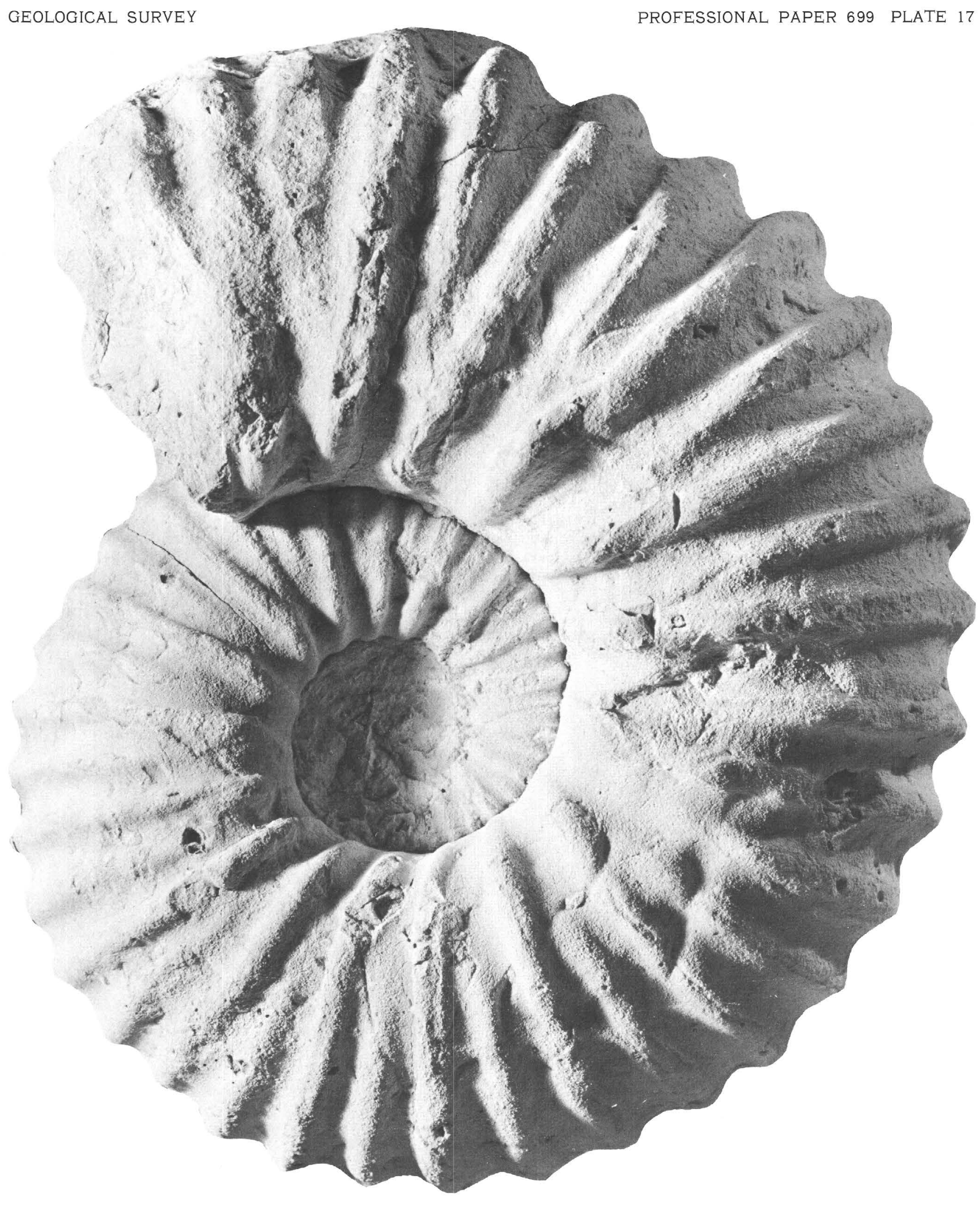

CALYCOCERAS NA VICULARE 


